\title{
De noodtoestand in het Belgische publiekrecht
}

Geert Van Haegenborgh en Willem Verrijdt ${ }^{*}$

I. De noodtoestand maakt inherent deel uit van het grondwettelijk recht. ${ }^{\mathrm{I}}$ Hoezeer de grondwetgever zich inspant om de werking van de instellingen op een principiële en pragmatische wijze te regelen en hoe sterk hij ook inzet op de rechtsbescherming van de burger, toch kan hij niet vermijden dat zich soms crisissituaties voordoen waarin de normale werking van de grondwettelijke regels op het spel komt te staan. De vraag of en onder welke voorwaarden het bekampen van noodtoestanden een afwijking van de Grondwet rechtvaardigt, raakt aan de kern van het constitutionalisme en is cruciaal in de verhouding tussen de overheid en haar burgers.

Toch is dit leerstuk onderbelicht in het hedendaagse Belgische staatsrecht. De publiekrechtelijke noodtoestand wordt zelfs niet gedefinieerd in het belangrijkste juridische woordenboek, dat enkel een lemma wijdt aan het begrip 'noodtoestand' in het strafrecht en in het verbintenissenrecht. ${ }^{2}$ Dit heeft veel te maken met artikel I87 van de Grondwet, dat bepaalt dat de Grondwet noch geheel, noch ten dele kan worden geschorst en dat zich verzet tegen het formeel afkondigen of het de facto invoeren van de uitzonderingstoestand.

Hoewel die bepaling het theoretische debat over het staatsnoodrecht in België onderdrukt, doen zich in realiteit wel degelijk noodtoestanden voor, met een variërende intensiteit, en de overheid is verplicht om daaraan binnen de kortste keren te verhelpen. Zij dient dat te doen binnen het bestaande juridische kader, dat door de rechters zeer welwillend wordt geïnterpreteerd en toegepast om de overheid daartoe, binnen zekere grenzen, de nodige ruimte te geven.

2. In de onderhavige bijdrage onderzoeken we eerst het grondwettelijke kader inzake noodtoestanden, waarin artikel I87 van de Grondwet de voornaamste plaats inneemt, maar waarbij enkele bijzondere bepalingen inzake de staat van oorlog niet mogen worden veronachtzaamd. In het tweede hoofdstuk wordt onderzocht

* Geert Van Haegenborgh is referendaris bij het Hof van Cassatie. Willem Verrijdt is referendaris bij het Grondwettelijk Hof en vrijwillig wetenschappelijk medewerker aan de KU Leuven.

I Cfr. J.P. Loof, Mensenrechten en staatsveiligheid: verenigbare grootheden? Opschorting en beperking van mensenrechtenbescherming tijdens noodtoestanden en andere situaties die de staatsveiligheid bedreigen, Nijmegen, Wolf Legal Publishers, 2005, 23.

2 E. Dirix, B. Tilleman en P. Van Orshoven (eds.), De Valks juridisch woordenboek, Antwerpen, Intersentia, 20II, 277. Ook in de rechtspraak van het Grondwettelijk Hof werd het begrip 'noodtoestand' tot nu toe slechts vermeld in een strafrechtelijke context (bvb. GwH nr. I27/2013, 26 september 20I3). 
of en in welke mate het verdragsrechtelijke kader inzake noodrecht dat grondwettelijke kader beïnvloedt. Het derde hoofdstuk is een reality check: de oplossingen die de drie staatsmachten in de praktijk hebben gegeven aan verschillende noodtoestanden die zich hebben voorgedaan, worden besproken en worden aan het voormelde grondwettelijke kader getoetst. Tot slot behandelen we in het vierde hoofdstuk de vraag of het besproken grondwettelijke kader aan herziening toe is.

\section{De 'noodtoestand' in de Belgische Grondwet}

3. De Belgische Grondwet vermeldt het begrip 'noodtoestand' niet en voorziet evenmin in een algemene mogelijkheid om in crisissituaties bepaalde grondwettelijke regels inzake de normale werking der instellingen of bepaalde grondrechten terzijde te schuiven. Hooguit verwijzen enkele bijzondere grondwetsbepalingen naar specifieke noodtoestanden, meer bepaald oorlogssituaties (zie nr. 29). Voor het overige is er slechts artikel I87 van de Grondwet, dat zich opwerpt als een dam tegen bijna elke vorm van staatsnoodrecht.

In dit hoofdstuk wordt eerst gefocust op de draagwijdte van artikel I87 van de Grondwet. Dit geschiedt aan de hand van een ideeënhistorische analyse van de redenen die het Nationaal Congres ertoe hebben gebracht om deze bepaling in de Grondwet op te nemen en die pleiten voor een zeer ruime interpretatie ervan. Daarna volgt een typologie van de situaties waarin een gehele of gedeeltelijke schorsing van de Grondwet aan de orde kan zijn. Tot slot wordt nader ingegaan op de grondwettelijke en wettelijke regeling van de staat van oorlog en de staat van beleg.

\section{I.I Artikel I87 van de Grondwet en het verbod op staatsnoodrecht}

4. Artikel I87 van de Grondwet, een bepaling die ongewijzigd is overgeleverd sinds I83I (toen nog artikel I30) en die ook tijdens de huidige legislatuur niet voor herziening vatbaar is, ${ }^{3}$ luidt als volgt: "De Grondwet kan noch geheel, noch ten dele worden geschorst." Het fundamentele karakter van die grondwetsbepaling werd door menig auteur beklemtoond: zij is, samen met artikel 33 van de Grondwet, ${ }^{4}$ een evidente bevestiging van de suprematie van de Grondwet en zij verwoordt het grondwettigheidsbegrip zelf. ${ }^{5} \mathrm{Zij}$ beklemtoont dat de drie staatsmachten en elk overheidsorgaan de Grondwet in alle omstandigheden moeten naleven. ${ }^{6}$ Tevens biedt zij de juridische grondslag van het continuïteitsbeginsel.7

3 Verklaring tot herziening van de Grondwet van 25 april 20I4, BS 28 april 20I4, p. 35I84.

$4 \quad$ Krachtens die bepaling gaan alle machten uit van de Natie en moeten zij worden uitgeoefend op de wijze bij de Grondwet bepaald.

5 J. De MeYer, Staatsrecht, Leuven, I975, 74; J. Velu, Droit public, I, Le statut des gouvernants, Brussel, Bruylant, I986, 2 II.

6 O. Orban, Le droit constitutionnel de la Belgique, I, Luik, Dessain, I906, 33I.

7 E. VAN Hooydonck, "Het artikel Izo van de Grondwet als algemene grondslag van het bestendigheidsbeginsel in het administratief recht”, ТBP ı992, 82-86. 
5. Deze grondwetsbepaling was niet opgenomen in een van de ontwerpteksten van de Grondwet, maar is het resultaat van een amendement van congreslid VAN SNICK, die op de vergadering van het Nationaal Congres van 5 februari I83I de goedkeuring van het volgende amendement vroeg: "Les pouvoirs constitutionnels n'existant que par la constitution, ils ne peuvent dans aucun cas, ni sous aucun prétexte, en suspendre l'action." Hij verklaarde dat de voorgestelde tekst werd geïnspireerd door de Franse liberale theoreticus Constant De RebecQue, die een belangrijke ideologische bezieler van de Belgische revolutionairen was. ${ }^{8}$ In zijn Cours de politique constitutionnelle breekt deze liberale denker een lans voor de theorie van de onschendbaarheid van de Grondwet: de staatsmachten hebben hun bestaan te danken aan de Grondwet, zodat zij deze niet kunnen schorsen. ${ }^{9}$ Het beginsel van de soevereiniteit wordt door CONSTANT gerelativeerd door het beklemtonen van de betekenis van de Grondwet als bestaansreden van de staatsmachten en, bij uitbreiding, als bron van elke rechtsregel.

Congreslid VAN SNICK verwees voorts naar de turbulente omstandigheden in Frankrijk (zie nr. 6), waar de Grondwet keer op keer werd geschorst door de machthebbers onder het mom dat het welzijn van het volk de hoogste wet moet zijn. Het ciceroniaanse adagium "Salus populi suprema lex esto" achtte dit congreslid evenwel niet overtuigend, omdat precies de Grondwet en de juiste toepassing van de wet waarborgen zijn voor het welzijn van de burger. ${ }^{\text {Io }}$

6. Verslaggever RAIKEM betuigde zijn steun aan het amendement, dat naar zijn mening terecht wilde verhinderen dat een der drie staatsmachten de Grondwet zou schenden. Congreslid Lebeau was eveneens een groot voorstander van het amendement en verklaarde kordaat dat indien de Franse Charte van 4 juni I8I4 een derge-

$8 \quad$ Zie A. AlEN, Rechter en bestuur in het Belgische publiekrecht. De grondslagen van de rechterlijke wettigheidscontrole, I, Antwerpen, Kluwer, I984, I66-I67.

9 B. Constant, Cours de politique constitutionnelle, II4-I45 (geciteerd door A. Alen, Rechter en bestuur in het Belgisch Publiekrecht, I67). Zie ook zijn Esquisse d'une Constitution, 373: "Un gouvernement constitutionnel cesse de droit d'exister aussitôt que la Constitution n'existe plus, et une Constitution n'existe plus dès qu'elle est violée. Le gouvernement qui la viole déchire son titre" (geciteerd door J.-J. Thonissen, La Constitution belge annotée, Brussel, Bruylant, I876, 390).

Io Zie voor een integrale weergave van de bespreking: E. Huyttens, Discussions du Congrès National de Belgique 1830-1831, II, Brussel, Société Typographique Belge, I844, 464-465. We geven hieronder de belangrijkste verklaringen weer van de congresleden VAN SNICK, RAIKEM en LEBEAU:

M. VAN SNicK: "Vous le savez, messieurs, tous les pouvoirs qui se sont succédés en France ont tour à tour violé et suspendu les constitutions qui devaient régir immuablement ce pays, et ce, en invoquant chaque fois la grande loi: Salus populi suprema lex esto. Comme si le salut du peuple n'était pas toujours attaché à l'inflexible exécution des lois, et surtout de la loi fondamentale. La proposition que je vous ai soumise, et sur le mérite de laquelle vous prononcerez, n'a d'autre objet que de prévenir ces infractions, ces suspensions et ces coups d'État, dont je viens de parler."

M. RAIKEM, rapporteur: "Le but de cet amendement est de prévenir qu'aucun pouvoir constitutionnel ne suspende la constitution; je l'appuie."

M. VAN SNICK: "Le but de la proposition est de prévenir ce qui est arrivé en France sous la république. On y a plus d'une fois suspendu la constitution dans plusieurs départements désignés dans une loi. Je me joins à l'amendement de M. Beyts."

M. Lebeau se prononce vivement pour l'adoption de l'amendement. "Il nefaut", dit-il, "négliger aucune garantie, et prévenir jusqu'à la possibilité d'une violation. Si la charte française avait contenu un semblable article, jamais les ministres de Charles X n'auraient pu trouver un prétexte pour suspendre la charte." 
lijke bepaling zou hebben gehad, de ministers van Karel X nooit een voorwendsel hadden kunnen vinden om die grondwettelijke tekst te schorsen. Zijn stellingname verwijst naar de Ordonnantiën van Saint-Cloud, die werden bekendgemaakt op 26 juli I830 en die onder meer de opschorting van de persvrijheid inhielden, de ontbinding van de Kamer bevolen (hoewel het nieuw verkozen parlement nog niet had kunnen vergaderen), een wijziging van het cijnskiesstelsel oplegden om het aantal kiezers te verminderen en een datum voor nieuwe verkiezingen bepaalden. De ordonnantiën werden beschouwd als een echte staatsgreep uitgaande van Karel X en de regering-de Polignac. Ze steunden op een bepaling van objectief staatsnoodrecht in de Charte van 4 juni I8I4 die duidelijk werd misbruikt voor de politieke doeleinden van de ultramonarchisten. ${ }^{\mathrm{II}}$

7. Welk licht werpen de verklaringen in het Nationaal Congres op artikel I87 van de Grondwet? Het is inderdaad zo dat de grondwetgever door de goedkeuring van het verbod om de Grondwet te schorsen een dam wilde opwerpen tegen mogelijke staatsgrepen. Er is echter meer. De ontstaansgeschiedenis van artikel 187 van de Grondwet is niet in overeenstemming te brengen met een minimalistische uitlegging, waarbij de relevantie van de tekst beperkt zou blijven tot dit soort van bedreigingen. VAN SNICK waarschuwde immers tegen de rechtsspreuk "Salus populi suprema lex esto", die uitdrukking geeft aan de gedachte dat de overheid, wanneer Staat of volk in nood verkeren, het ongeschreven recht heeft om het objectief recht buiten werking te stellen. Het uitgangspunt van het onaantastbaar karakter van de Grondwet, dat een inspiratiebron was voor het Nationaal Congres, staat haaks op dit adagium en is relevant voor de uitlegging van artikel I87 van de Grondwet. Uit de bespreking in het Nationaal Congres mag worden afgeleid dat de bedoeling van de grondwetgever erin bestond om in de Belgische rechtsorde de opschorting van de fundamentele regels van de staatsinrichting en van de rechten en vrijheden van de burger onmogelijk te maken.

\section{b. Een absoluut beletsel voor de schorsing van de Grondwet}

8. Op grond van zijn ontstaansgeschiedenis ziet OrBAN artikel I87 van de Grondwet dan ook terecht als de negatie van het geciteerde adagium. Hij merkt op dat die grondwetsbepaling niet in enige uitzondering voorziet en in duidelijke bewoordingen is geformuleerd. ${ }^{12}$ Het toepassingsgebied ervan is bijgevolg ruim en niet te herleiden tot enige specifieke hypothese. ${ }^{13}$

In navolging hiervan interpreteert een aanzienlijk deel van de rechtsleer artikel I87 van de Grondwet als een absoluut beletsel voor de schorsing van de Grondwet, en dit ongeacht de reden (staat van oorlog, opstanden of terrorisme) die hiervoor

II Artikel I4 van de Charte van 4 juni I8I4: "Le Roi est chef suprême de l'État, il commande les forces de terre et de mer, déclare la guerre, fait les traités de paix, d'alliance et de commerce, nomme à tous les emplois d'administration publique, et fait les règlements et ordonnances nécessaires pour l'exécution des lois et la sûreté de l'État."

I2 O. Orban, Le droit constitutionnel de la Belgique, I, Luik, H. Dessain, I906, 333, nr. I99.

I3 E. VAN Hoordonk, "Het artikel Izo van de Grondwet als algemene grondslag van het bestendigheidsbeginsel in het administratief recht", ТBP I992, (75), 82-84. 
wordt ingeroepen. ${ }^{14}$ Wetgeving die bepalingen bevat voor de uitoefening van bevoegdheden in noodtoestanden en die het mogelijk maakt om af te wijken van het normale constitutionele regime, zou onmiskenbaar een schending van die grondwetsbepaling inhouden. ${ }^{15}$ Objectief staatsnoodrecht dat gepaard gaat met het te verregaand beperken of opschorten van de fundamentele rechten en vrijheden of met een vermindering van de controle op het optreden van de overheid is derhalve niet verenigbaar met de duidelijke tekst van artikel I87 van de Grondwet. Die zienswijze sluit aan bij het uitgangspunt van congreslid VAN SNICK, die beklemtoonde dat de machten maar bestaan krachtens de Grondwet, zodat zij haar in geen enkel geval kunnen schorsen. Voor een handelen gewettigd door de "raison d'état" maar in strijd met de Grondwet liet het Nationaal Congres geen ruimte.

9. In dit opzicht dient wel een onderscheid te worden gemaakt tussen het "schorsen" van (delen van) de Grondwet en het "beperken" van bepaalde rechten die door de Grondwet worden gewaarborgd. Een schorsing betekent dat bepaalde delen van de Grondwet tijdelijk (formeel of de facto) buiten toepassing worden gesteld, terwijl een beperking inhoudt dat een grondrecht onverkort van toepassing blijft, maar dat een maatregel wordt genomen die er op het eerste gezicht niet mee verenigbaar is. Die beperking kan doorgaans worden gerechtvaardigd, aangezien de meeste grondrechten niet absoluut zijn. Maar niettemin kan die beperking door de bevoegde rechter worden getoetst aan het betrokken grondrecht, dat onverkort van toepassing blijft. Het wezenlijke verschil tussen het schorsen en het beperken van delen van de Grondwet komt dus neer op het al dan niet onttrekken aan de rechterlijke toetsing van bepaalde handelingen van de wetgevende en de uitvoerende macht. Een schorsing raakt aldus aan een essentieel kenmerk van de rechtsstaat.

De Belgische Grondwet kent een stelsel van formele beperkingen van grondrechten, terwijl de mensenrechtenverdragen inhoudelijke beperkingscriteria opleggen. ${ }^{16}$ De Grondwet schrijft voor de meeste grondrechten voor dat beperkingen slechts bij formele wet kunnen worden aangenomen. Daarnaast zijn regelende en repressieve maatregelen steeds toegelaten, ${ }^{17}$ terwijl preventieve beperkingen, die neerkomen op een voorafgaand verlof om het grondrecht uit te oefenen, voor de meeste grondrechten verboden zijn. ${ }^{8}$ De meeste mensenrechtenverdragen schrij-

I4 Bvb. R. Senelle, Commentaar op de Belgische grondwet in Teksten en documenten. Ideeën en Studies, nr. 30I, Brussel, Ministerie van Buitenlandse Zaken, Buitenlandse Handel en Ontwikkelingssamenwerking, 1974, 438; M. Verdussen, La constitution belge. Lignes et entrelignes, Brussel, Le Cri, 2004, I85 en I88: "Quelles que soient la gravité et l'intensité de la menace, il ne saurait être question de s'écarter des règles constitutionnelles. Car un Etat qui régresse dans la protection constitutionnelle du citoyen est un Etat qui s'éloigne de l'idéal démocratique."

I5 K. RimanQue, De grondwet toegelicht, gewikt en gewogen, Antwerpen-Groningen, Intersentia, I999, 366; zie J. Velaers en S. Van Drooghenbroeck, "Invoeging van een transversale bepaling in de Grondwet over het afwijken van rechten en vrijheden", Parl. St. Kamer 2005-2006, nr. 5I-2304/00I, p. 6I.

i6 A. Alen en K. Muylle, Handboek van het Belgisch Staatsrecht, Mechelen, Kluwer, 20II, 78-79 en 7958oI.

I7 Een regelende beperking beoogt de ordelijke uitoefening van de rechten en vrijheden, zonder deze wezenlijk aan te tasten. Een repressieve maatregel bestraft misdrijven die naar aanleiding van die uitoefening worden gepleegd.

I8 Enkel de "bijeenkomsten in open lucht" blijven krachtens artikel 26, tweede lid, van de Grondwet ten volle onderworpen aan de politiewetten in materiële zin. Het Hof van Cassatie heeft die uitzondering uitgebreid tot alle grondrechten, zodra zij op de openbare wegen en pleinen worden 
ven voor dat grondrechten slechts mogen worden beperkt bij (materiële) wet, voor zover die beperkingen nodig zijn in een democratische samenleving ter bescherming van bepaalde rechtsgoederen. Indien een grondrecht in het geding is dat zowel in de Belgische Grondwet als in een mensenrechtenverdrag wordt gewaarborgd, vereist het Grondwettelijk Hof dat een beperking ervan cumulatief aan beide types van beperkingscriteria voldoet. ${ }^{19}$ In de praktijk komt die toets doorgaans vooral neer op het onderzoek naar de evenredigheid tussen het nagestreefde doel en de gevolgen van de maatregel voor de burgers wier vrijheden worden beperkt. ${ }^{20}$

Een loutere beperking van een grondrecht is op zichzelf dus niet problematisch in het licht van artikel I87 van de Grondwet, temeer daar de rechterlijke toetsing waarin de Grondwet zelf voorziet ${ }^{21}$ intact blijft. Wel kan worden gesteld dat een geheel van zeer verregaande beperkingen van verschillende grondrechten op hetzelfde ogenblik, die niet kunnen worden gerechtvaardigd aan de hand van de voormelde criteria, de facto op een schorsing kan neerkomen en dus op gespannen voet kan staan met artikel I87 van de Grondwet.

\section{c. De staat van beleg als uitzondering op artikel I87 van de Grondwet?}

Io. Hoewel de tekst van artikel I87 van de Grondwet een algemene draagwijdte heeft, argumenteren sommige auteurs dat het verbod om de Grondwet te schorsen, niet van toepassing is in geval van de staat van beleg in oorlogstijd. Men kan die stelling slechts begrijpen in het licht van de negentiende-eeuwse Franse wetgeving op de staat van beleg. Deze bepalingen op het gebied van de uitwendige en inwendige veiligheid zijn opgenomen in de wet van 8-Io juli I79I "concernant la conservation et le classement des Places de guerre et Postes militaires, la police des Fortifications et autres objets y relatifs", de wet van Io Fructidor jaar V (27 augustus 1797) en het keizerlijk decreet van 24 december I8I "relatifà l'organisation et au service des Etats-majors des places". ${ }^{22}$ Op grond van de wet van 8 -ro juli I79I treedt de staat van beleg in

uitgeoefend (Cass. 23 januari I879, Pas. I879, I, 75; Cass. 29 oktober 1973, Arr.Cass. 1974, 243), terwijl de Raad van State, afdeling Bestuursrechtspraak die uitzondering enkel toepast op openbare vergaderingen (RvS, Van der Vinck, nr. 80.282, I8 mei I999; RvS, S. en AGALEV, nr. I03.730, I9 februari 2002).

I9 GwH nr. 202/2004, 2I december 2004.

20 M. Verdussen, Justice constitutionnelle, Brussel, Larcier, 20I2, I34-I35.

2I Zie in het bijzonder de artikelen I42 (Grondwettelijk Hof) en I59 (rechterlijk wettigheidstoezicht) van de Grondwet.

22 Zie nader J.P. Loof, Mensenrechten en staatsveiligheid: verenigbare grootheden?, Nijmegen, Wolf Legal Publishers, 2005, 46-49. Hieronder volgt de tekst van de belangrijkste bepalingen:

- artikel 2 van de wet van ro Fructidor jaar V (27 augustus 1797): "Les communes de l'intérieur seront en état de siège aussitôt que, par l'effet de leur investissement par des troupes ennemies ou par des rebelles, les communications du dedans au-dehors et du dehors au-dedans seront interceptées à la distance de trois mille cinq cent deux mètres (dix-huit cents toises) des fossés ou des murailles; dans ce cas, le Directoire exécutif en préviendra le Corps législatif";

- artikel ro van de wet van Io juli I79I: "Dans les places de guerre et postes militaires, lorsque ces places et postes seront en état de siège, toute l'autorité dont les officiers civils sont revêtus par la Constitution, pour le maintien de l'ordre et de la police intérieurs, passera au commandant militaire, qui l'exercera exclusivement, sous sa responsabilité personnelle";

- artikel II van de wet van io juli I79I: "Les places de guerre et postes militaires seront en état de siège, non seulement dès l'instant que les attaques seront commencées, mais même aussitôt que, par l'effet de leur investissement par des troupes ennemies, les communications du dehors au dedans et du dedans au dehors seront interceptées, à la distance de dix-huit cent toises des crêtes des chemins couverts"; 
zodra een vesting of versterkte plaats wordt aangevallen of ingesloten raakt. De wet volstond echter niet om in alle omstandigheden efficiënt te kunnen optreden, zodat de wet van ro Fructidor jaar V en het decreet van 24 december I8II bijkomend toelaten dat de Keizer de fictieve staat van beleg uitroept in andere plaatsen dan een bedreigde of belegerde stad. Het uitroepen van de fictieve staat van beleg kan niet alleen in oorlogsomstandigheden, maar ook bij opstand of rebellie.

in. De Brouckère en Tielemans zijn van oordeel dat de Belgische Grondwet zich ertegen verzet dat de Koning de fictieve staat van beleg uitroept om een einde te maken aan oproer of onlusten. Dit betekent immers een opschorting van de normale werking van de instellingen en van de bescherming van fundamentele rechten en vrijheden. Tegen het uitroepen van de werkelijke staat van beleg, die van toepassing is in de vestingen en militaire posten wanneer zij worden aangevallen of ingesloten zijn, zou daarentegen vanuit grondwettelijk oogpunt geen bezwaar bestaan. ${ }^{23}$

I2. De bespreking tijdens het Nationaal Congres biedt echter weinig steun voor die stelling. Burggraaf Charles VILAIN XIIII merkte op dat het Nationaal Congres door de goedkeuring van de voorgestelde tekst de invoering van de staat van beleg bij een versterkte plaats onmogelijk zou maken. ${ }^{24}$ Die overweging werd niet tegengesproken door de andere leden en kon de goedkeuring van artikel I87 van de Grondwet niet verhinderen. Daaruit mag worden afgeleid dat de Franse wetgeving op de staat van beleg in haar geheel stilzwijgend is opgeheven door de Belgische Grondwet. ${ }^{25}$ Dit is ook de zienswijze van Ganshof van Der Meersch, die in zijn preadvies benadrukte dat een noodregime ter bestrijding van oproer of sociale onlusten strijdig is met artikel I87 van de Grondwet en dat de bevoegdheden die de

- artikel I2 van de wet van Io juli I79I: "Létat de siège ne cessera que lorsque l'investissement sera rompu, et, dans le cas où les attaques auraient été commencées, qu'après que les travaux des assiégeants auront été détruits, et que les brèches auront été réparées ou mises en état de défense";

- artikel 53 van het decreet van 24 december I8II: "L'état de siège est déterminé par un décret de l'Empereur, ou par l'investissement, ou par une attaque de vive force, ou par une surprise, ou par une sédition intérieure, ou enfin par des rassemblements formés dans le rayon d'investissement, sans l'autorisation des magistrats. Dans le cas d'une attaque régulière, l'état de siège ne cesse qu'après que les travaux de l'ennemi ont été détruits, et les brèches mises en état de défense. Dans ces différents cas, les fonctions et obligations des commandants d'armes sont soumises aux règles établies ci-après, chapitre IV";

- artikel ror van het decreet van 24 december I8Ir: "Dans les places en état de siège, l'autorité dont les magistrats étaient revêtus pour le maintien de l'ordre et de la police passe, tout entière au commandant d'armes, qui l'exerce, ou leur en délègue telle partie qu'il juge convenable";

- artikel I02 van het decreet van 24 december I8II: "Le gouverneur ou commandant exerce cette autorité ou la fait exercer en son nom et sous sa surveillance, dans les limites que le décret détermine; et, si la place est bloquée, dans le rayon de l'investissement";

- artikel Io3 van het decreet van 24 december I8II: "Pour tous les délits dont le gouverneur ou le commandant n'a pas jugé à propos de laisser la connaissance aux tribunaux ordinaires, les fonctions d'officier de police judiciaire sont remplies par un prévôt militaire, choisi, autant que possible, parmi les officiers de gendarmerie; et les tribunaux ordinaires sont remplacés par les tribunaux militaires".

23 C. De Brouckère en F. Tielemans, Répertoire de l'administration et du droit administratif de la Belgique, $\mathrm{v}^{\circ}$ Force publique, t. VII, 436-437: "Nous acceptons l'état de siège avec toutes ces conséquences lorsqu'il est le résultat nécessaire d'un investissement ou d'une attaque, comme l'exige la loi du 8-10 juillet 1791; nous le repoussons au contraire comme résultat d'une volonté personnelle."

24 E. Hurtens, Discussions du Congrès National de Belgique 1830-1831, II, Brussel, Société Typographique Belge, I844, 465: "En admettant l'amendement on abolit l'article de je ne sais quel Code qui permet la mise en état de siège de places fortes."

25 J. Velaers, De beperkingen van de vrijheid van meningsuiting, II, Antwerpen-Apeldoorn, Maklu, I99I, 794-795. 
Koning, in dit opzicht, zou baseren op teksten die dateren van voor de Grondwet, hem onttrokken zijn op grond van die grondwetsbepaling en op grond van artikel I05 van de Grondwet. ${ }^{26}$

Zelfs indien die Franse wetgeving na de onafhankelijkheid van België nog van toepassing zou zijn, blijft het voorschrift van artikel I87 van de Grondwet, dat de schorsing van rechten en vrijheden verbiedt, overigens onverminderd van toepassing. ${ }^{27}$

\section{d. Artikel I87 van de Grondwet en de oorlogstijd}

I3. Ook los van de hypothese van het uitroepen van de staat van beleg blijft de vraag of artikel I87 van de Grondwet zich verzet tegen een schorsing van de Grondwet in oorlogstijd. ButtgenBACH verdedigde de opvatting dat de Belgische Grondwet van I83I een grondwet is voor vredestijd, omdat de leden van het Nationaal Congres doordrongen waren van de noodzaak van een neutraliteitspolitiek die een deelname aan oorlogen tussen andere mogendheden uitsloot. ${ }^{28}$ In dezelfde zin merkte Procureur-generaal TERLINDEN in zijn conclusie voor het arrest van het Hof van Cassatie van II februari I9I9 op dat een grondwet alleen een regeling kan inhouden voor normale omstandigheden en niet voor onvoorziene buitengewone omstandigheden. De leer van de grondwet in vredestijd werd ook aangenomen door GansHOF VAN DER MEersch in zijn preadvies van $1950 .{ }^{29}$ De grondwetgever zou "de gedachte van een oorlog van zich af hebben gezet" en, uitgaande van de aanwezigheid van de normale vereisten voor de uitoefening der machten, het verbod van schorsing van de Grondwet hebben ingesteld.

I4. De opvatting dat de Belgische grondwetgever geen aandacht heeft besteed aan de hypothese van oorlog of andere uitzonderlijke omstandigheden is echter niet juist. Op grond van artikel 68, eerste lid, van de Grondwet van I83I (thans artikel I67, § I, tweede lid, van de gecoördineerde Grondwet) verklaart de Koning de oorlog en stelt hij het einde van de vijandelijkheden vast (zie nr. 3I). De hypothese van een oorlog was in de negentiende-eeuwse context van net na de Belgische revolutie niet naar de achtergrond gedrongen. Op grond van artikel I3rbis (thans artikel I96) van de Grondwet, dat weliswaar pas werd ingevoegd bij de grondwets-

26 W.J. Ganshof van der Meersch, Preadvies. De schorsing van de vrijheidsrechten in uitzonderingstoestand, in Vereniging voor de vergelijkende studie van het recht van België en Nederland Jaarboek III 1949-1950, Antwerpen, De Sikkel, Zwolle, W.E.J. Tjeenk Willink, 2I-22; Anders R. Ergec en S. Watthee, "Les dérogations aux droits constitutionnels", in M. Verdussen en N. Bonbled (eds.), Les droits constitutionnels en Belgique, Brussel, Bruylant, 20II, 406.

27 Vgl. J. Velaers, De beperkingen van de vrijheid van meningsuiting, II, Antwerpen-Apeldoorn, Maklu, I99I, 795, die opmerkt dat de gevolgen van de staat van beleg naar Frans recht niet de uitoefening van rechten en vrijheden raken, zodat aan het eventueel voortbestaan van die wetgeving geen decisief argument kan worden ontleend voor een schorsing van grondrechten in oorlogstijd.

28 A. Buttgenbach, "L'extension des pouvoirs de l'exécutif en temps de guerre et la révision de la Constitution belge", Belg. Jud., I935, 394. Zie later ook R. Ergec, "L'état de nécessité en droit constitutionnel belge", in Interuniversitair Centrum voor Staatsrecht (ed.), Le nouveau droit constitutionnel, Brussel, Bruylant, I987, I45.

29 W.J. Ganshof van Der Meersch, Preadvies. De schorsing van de vrijheidsrechten in uitzonderingstoestand, in Vereniging voor de vergelijkende studie van het recht van België en Nederland Jaarboek III 1949-1950, Antwerpen, De Sikkel, Zwolle, W.E.J. Tjeenk Willink, I950, I3. 
herziening van 15 januari 1968 , mag geen herziening van de Grondwet worden ingezet of voortgezet in oorlogstijd of wanneer de Kamers verhinderd zijn vrij bijeen te komen op het nationale (sedert 1994 het "federale") grondgebied. We mogen er dan ook van uitgaan dat de waarborg die artikel I87 van de Grondwet biedt, niet wegvalt zodra de Koning de mobilisatie afkondigt, hetgeen het aanvangspunt uitmaakt van de staat van oorlog (zie nr. 34$).^{30}$

Aangezien de Grondwet niet bepaalt dat de oorlogstijd van rechtswege leidt tot een opschorting van de Grondwet, vermag de overheid in beginsel ook in oorlogsomstandigheden de rechten en vrijheden en de normale werking van de instellingen niet te schorsen. Ubi constitutio non distinguit, nec nos distinguere debemus.

\section{e. Toch een algemene uitzondering op artikel I87 van de Grondwet: overmacht?}

I5. Het voorgaande betekent echter niet dat er geen omstandigheden denkbaar zijn waarin de waarborg van artikel I87 van de Grondwet zeer moeilijk te handhaven is. Quid immers in de hypothese dat de overheid door omstandigheden buiten haar wil in de absolute onmogelijkheid is om de Grondwet na te leven en er toch dringend moet gehandeld worden? Het begrip "overmacht" moet in deze context niet in zijn burgerrechtelijke betekenis worden begrepen, maar houdt verband met een toestand die tot gevolg heeft dat de overheid niet anders kan dan buiten de strikte grenzen van het recht optreden..$^{3 \mathrm{I}}$ Het gaat om een toestand die zich opdringt aan de overheid en die niet langer de mogelijkheid biedt om de rechten en vrijheden of de normale werking van de instellingen integraal te waarborgen. ${ }^{22}$

Reeds onmiddellijk na zijn eedaflegging zag Leopold I, de eerste Belgische Koning, zich geconfronteerd met een overmachtssituatie toen de Nederlandse troepen op 2 augustus I83 het land binnenvielen en hun opmars verderzetten naar Brussel. Op grond van het toenmalige artikel I2I (thans artikel I85) van de Grondwet had de Koning een wettelijke machtiging nodig van de Kamers om de bijstand te vragen van de troepen van de Franse Koning Louis Philippe. Vermits hij in de onmogelijkheid was om eerst de Kamers bijeen te roepen, vroeg de Koning onmiddellijk de hulp van het Franse leger. De maatregel werd goedgekeurd door de publieke opinie en gaf geen aanleiding tot een staatkundig probleem. ${ }^{33}$

30 J. Velaers en S. Van Drooghenbroeck, "Invoeging van een transversale bepaling in de Grondwet over het afwijken van rechten en vrijheden", Parl. St. Kamer 2005-2006, nr. 5I-2304/oor, p. 68.

3 I Zie bvb. Cass. II juni I953, Arr.Cass. I953, 687: "de noodzakelijkheid van de ononderbroken en vaste bezetting van de ambten der gestelde overheden vereist, in geval deze komen te verdwijnen, dat onverwijld in hun vervanging wordt voorzien en laat toe voorlopig in zodanig ontbreken der overheden te voorzien, zonder dat op strikte wijze de wettelijke vormen behoeven te worden in acht genomen, wanneer de in acht te nemen bepalingen, ten gevolge van overmacht, niet uitvoerbaar zijn geworden."

32 O. Orban, Le droit constitutionnel de la Belgique, I, Luik, H. Dessain, I9o6, 334-335, die de overmacht definieert als "une situation où il n'y aurait pas moyen de faire autrement que de sortir des bornes du droit".

33 O. Orban, Le droit constitutionnel de la Belgique, I, Luik, H. Dessain, I9o6, 335; J.J. Thonissen, La Constitution belge annotée, Brussel, Bruylant, I876, 369-370. Zie ook Pasinomie I83I-I832, I42: "S'il faut vivement regretter que l'imminence du danger n'ait pas permis alors au Gouvernement de réunir les mandataires de la nation, pour sanctionner, comme ils l'eussent fait, les mesures commandées par le salut de l'Etat, la Belgique n'en a pas moins vu avec reconnaissance qu'au premier signal elle pouvait compter sur l'amitié du peuple français et sur le soutien de son puissant monarque." 
I6. In het publiekrecht hangt de situatie van overmacht nauw samen met het beginsel van de continuïteit van de openbare dienst, dat zelf zijn grondslag vindt in artikel I87 van de Grondwet: zelfs indien zich een situatie van overmacht voordoet, dienen de wezenlijke functies van de Staat blijvend te worden uitgeoefend, ook al moet dit dan noodzakelijkerwijze gebeuren op een wijze die niet in de Grondwet zelf is bepaald. ${ }^{34}$ Een niet-uitoefening van de door de Grondwet vermelde machten houdt een minstens even wezenlijke schorsing van de Grondwet in als de tijdelijke uitoefening ervan door het verkeerde orgaan. Deze redenering heeft er met name toe geleid dat de besluitwetten van Londen en van Le Havre door het Hof van Cassatie werden aanvaard (zie nr. 55). Vele auteurs aanvaarden het beginsel van overmacht dan ook als grondslag van tijdelijk staatsnoodrecht voor zover daarbij wordt afgeweken van de grondwetsbepalingen die de werking van de instellingen regelen. ${ }^{35}$ Tegen de gevolgen van overmacht kan immers geen enkele bepaling bescherming bieden, en zelfs artikel I87 van de Grondwet beschermt enkel tegen de overheid, niet tegen overmacht. ${ }^{36}$

I7. Daarentegen is de vraag of een werkelijke noodtoestand ook een schorsing van de rechten en vrijheden rechtvaardigt, meer betwist. Sommigen achten dit gerechtvaardigd, voor zover het overheidsoptreden ook in dat geval steeds de beginselen van evenredigheid en subsidiariteit in acht neemt. ${ }^{37}$ VAN Drooghenbroeck werpt hiertegen terecht op dat een materiële onmogelijkheid voor de overheid om, zelfs in oorlogstijd, bepaalde rechten en vrijheden te waarborgen, moeilijk denkbaar is. Het schorsen van rechten en vrijheden is dan immers het gevolg van een vrije keuze door de overheid die wordt ingegeven door een noodtoestand. ${ }^{8}$

Die laatste stelling kan worden bijgetreden. Een situatie van overmacht kan maatregelen vereisen die grondrechten beperken, maar er valt niet in te zien hoe een dergelijke situatie ook kan vereisen dat de overheid het genot van een grondrecht schorst, met als voornaamste gevolg dat ook de rechterlijke toetsing a posteriori van de genomen maatregelen wordt uitgeschakeld (zie nr. 9). Infra zal worden aangetoond dat de rechters in geval van werkelijke crisissituaties de evenredigheidstoets zeer terughoudend toepassen, teneinde de overheid de juridische ruimte te bieden om die situaties effectief te bekampen (zie nr. Io6). Ook bij toepassing van artikel I5 EVRM worden de geviseerde grondrechten overigens niet buiten werking gesteld en blijft de controle door het EHRM overeind (zie nr. 47).

34 J. Velaers en S. Van Drooghenbroeck, "Invoeging van een transversale bepaling in de Grondwet over het afwijken van rechten en vrijheden", Parl. St. Kamer 2005-2006, nr. 5I-2304/ooI, p. 64 .

35 C. Huberlant, "Etat de siège et légalité d'exception en Belgique", in Licéité en droit positifet références légales aux valeurs, Brussel, Bruylant, I982, 427-429; W.J. Ganshof van der Meersch, Preadvies. De schorsing van de vrijheidsrechten in uitzonderingstoestand, Preadvies, Zwolle, Tjeenk Willink, I950, 6o; J. Velaers, De beperkingen van de vrijheid van meningsuiting, Antwerpen, Maklu, I99I, II, 796; L. Wodon, "Sur le rôle du Roi, comme chef de l'Etat dans les cas de défaillances constitutionnelles", Bulletin, Académie Royale, I94I, 217-218.

36 J. Velaers en S. Van Drooghenbroeck, "Invoeging van een transversale bepaling in de Grondwet over het afwijken van rechten en vrijheden", Parl. St. Kamer 2005-2006, nr. 5I-2304/00I, p. 62; P. Wigny, Droit constitutionnel. Principes et droit positif, I, Brussel, Bruylant, I952, 200, nr. Io8.

37 E.T. Brainich von Brainich Felth, Staatsnoodrecht, Zwolle, Tjeenk Willink, i993, 76-77 en 8I-82.

38 S. Van Drooghenbroeck, "L'article i87 de la Constitution", RBDC 2006, (293), 295. 
I8. Door de afwijking in geval van overmacht te beperken tot tijdelijke afwijkingen van de grondwetsbepalingen die de bevoegdheden en de werking van de instellingen regelen, wordt ook vermeden dat het adagium Salus populi suprema lex esto weer om de hoek komt kijken en dat de absolute gelding van artikel I87 van de Grondwet wordt aangetast.

f. Noodrecht ter bescherming van het beginsel van de onafhankelijkheid van het land?

I9. De Raad van State, afdeling Wetgeving, en advocaat-generaal bij het Hof van Cassatie Hayoit de Termicourt hebben geargumenteerd dat, ondanks artikel i87 van de Grondwet, er toch ruimte is voor staatsnoodrecht indien de noodtoestand van dien aard is dat de onafhankelijkheid van het land op het spel staat. De juridische grondslagen die hiervoor in het verleden zijn bedacht, bleken echter " $z$ wak en precair" te zijn. ${ }^{39}$ Het argument van de "grondwet voor vredestijd" en het argument van de Franse wetgeving op de staat van beleg werden hierboven reeds besproken (zie nrs. IO-I3). Hieronder wordt nog slechts ingegaan op het argument dat er een extra-constitutionele norm bestaat die de staatsmachten verplicht om de onafhankelijkheid van het land te handhaven.

20. In 1952 werd aan de afdeling Wetgeving van de Raad van State een advies gevraagd over een wetsontwerp van de regering-Van Houtte dat strekte tot een actualisering van de wetgeving op de buitengewone machten (zie nr. 74)..$^{\circ}$ Het wetsontwerp verleende aan de Koning de macht om wetskrachtige voorzieningen te treffen in oorlogstijd, wanneer de nood hem daartoe noopte. Die noodwetgeving moest kunnen bijdragen tot bepaalde doeleinden, zoals de veiligheid van de Staat, de continue werking van de openbare diensten en de vrijwaring van de economische, sociale en financiële belangen van het land. In geval van een gewapende aanval tegen 's Lands grondgebied werd door het wetsontwerp aan de Koning de macht verleend om de toegewezen bevoegdheid onmiddellijk uit te oefenen.

Het advies van de Raad van State laat er geen twijfel over bestaan dat een dergelijke wet indruist tegen artikel I87 van de Grondwet, omdat ze een gedeeltelijke schorsing van de Grondwet inhoudt. Hoewel het advies dit niet met zoveel woorden zegt, bevestigt de Raad van State impliciet maar zeker de ruime draagwijdte van artikel I87 van de Grondwet en de stelling dat deze bepaling haaks staat op noodwetgeving die afwijkingen inhoudt van het normale constitutionele regime.

2I. De Raad van State zocht niettemin toch een juridische grondslag voor de voorgestelde buitengewone machtenwet en verwijst naar het bestaan van "extraconstitutionele wetten" die zouden berusten op de noodzaak "om in abnormale omstandigheden het bestaan van de Natie te vrijwaren, zelfs ten koste van uitzonderlijke en van

39 J. Velaers en S. Van Drooghenbroeck, "Invoeging van een transversale bepaling in de Grondwet over het afwijken van rechten en vrijheden", Parl. St. Kamer 2005-2006, nr. 5I-2304/00I, p. 67-7I.

40 Advies Raad van State, afdeling Wetgeving, 9 juni 1952 over een wetsontwerp betreffende de toekenning aan de Koning van buitengewone machten in oorlogstijd, Parl. St., Kamer, 1952-53, nr. I72, p. II-I4. 
het gemeen recht afwijkende bepalingen". Het advies beklemtoont dat de noodtoestand "geen schepping is van (de) Staatswil, (omdat) de bevoegde overheid enkel het bestaan ervan kan vaststellen en in concreto kan beslissen welke maatregelen die toestand kunnen verhelpen".

De stelling van de Raad van State sluit aan bij een conclusie van advocaat-generaal HAYOIT De TERMicourt bij een arrest van het Hof van Cassatie van 4 maart I940, waarin hij de volgende redenering ontwikkelde: "Ayant mission d'assurer à la fois le respect du décret d'indépendance et celui de la Constitution, si l'indépendance nationale ne peut être maintenue que grâce à des lois de défense, entraînant une limitation temporaire de certaines libertés dont le principe est consacré par la Constitution, les organes législatifs ont le pouvoir, et j'ose dire le devoir, de sauvegarder, avant tout le fondement, même de ces libertés, c'est-à-dire de défendre contre l'étranger l'indépendance du pays." ${ }^{\prime 1}$

22. In haar advies verbond de afdeling Wetgeving van de Raad van State het bestaan van staatsnoodrecht ter vrijwaring van de onafhankelijkheid van het land aan vier voorwaarden. Ten eerste moet de noodzakelijkheid van de afwijking blijken. Ten tweede mag die noodzakelijkheid slechts betrekking hebben op een welbepaald doel, namelijk het verzekeren van het voortbestaan van de Belgische Staat. Ten derde moet de afwijking tijdelijk zijn. Ten vierde komt het alleen aan de wetgevende macht toe om de nodige maatregelen te nemen, aangezien deze "het residu van de soevereiniteit" bezit en het dus alleen aan hem toekomt om extra-constitutionele toestanden te regelen. Die bevoegdheid kan niet worden overgedragen, aangezien dan de soevereiniteit zou worden overgedragen. ${ }^{42}$

23. Het voormelde advies en de voormelde conclusie aanvaarden dus dat het behoud van de nationale onafhankelijkheid een extra-constitutionele norm is die vervat ligt in het decreet van het Nationaal Congres van I 8 november I830.43 Bij het decreet van 24 februari I83 I van het Nationaal Congres werd dat decreet - samen met het decreet van 24 november 1830 waarbij het huis Oranje-Nassau eeuwigdurend van elke macht in België werd uitgesloten - "onherroepelijk" verklaard. ${ }^{44}$ Het Nationaal Congres heeft die extra-constitutionele plicht niet ingeschreven in de Grondwet om te vermijden dat het beginsel van de onafhankelijkheid van het land net als elke andere grondwetsbepaling voor herziening vatbaar zou zijn. ${ }^{45}$

4I R. Hayoit de Termicourt, conclusie bij Cass., 4 maart i940, Pas. I946, I, (493), 497.

42 Advies Raad van State, afdeling Wetgeving, 9 juni 1952 over een wetsontwerp betreffende de toekenning aan de Koning van buitengewone machten in oorlogstijd, Parl. St., Kamer, I952-53, nr. I72, p. II.

43 Pasinomie $3^{\mathrm{e}}$ Série, I, 86. De officiële Franse tekst van dat decreet luidde als volgt: "Le Congrès National de la Belgique proclame l'indépendance du peuple belge, sauf les relations du Luxembourg avec la Confédération Germanique." De Nederlandse vertaling luidde als volgt: "Den Volksraed van België verklaert plegtiglyk de onafhankelykheyd van het Belgische volk, behoudens de betrekkingen van Luxemburg met het duytsche verbond" (die vertaling werd bekendgemaakt in: Bulletin officiel des décrets du Congrès National de la Belgique et des arrêtés du Pouvoir Exécutif, Brussel, Imprimerie de Weissenbruch père, I830, 585).

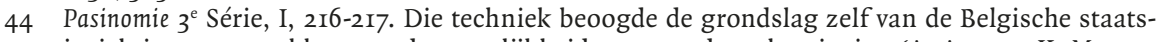
inrichting te onttrekken aan de mogelijkheid van grondwetsherziening (A. Alen en K. Muylle, Handboek van het Belgisch Staatsrecht, Mechelen, Kluwer, 20II, 235).

45 Hiervoor wordt doorgaans verwezen naar een verklaring van Congreslid Beyts: "en déclarant que nous les avons rendus comme Corps constituant, nous les rendons irrévocables; ils ne feront pas partie de la Constitution, mais ils seront la base sur laquelle elle repose" (J. Velaers en S. Van Drooghenbroeck, 
24. Die juridische grondslag en de erop gebaseerde redenering worden in de rechtsleer terecht betwist. Zij gaat er immers ten onrechte van uit dat een extraconstitutionele norm de grondrechten die door de formele Grondwet worden gewaarborgd, buiten werking kan stellen, een premisse die moeilijk in overeenstemming is te brengen met artikel 187 van de Grondwet. ${ }^{46}$ Ganshof VAN DER MeErsch en DiDERICH besluiten dan ook terecht dat een dergelijke logica slechts kan opgaan in een systeem dat geen grondwettigheidstoetsing van formele wetten kent. ${ }^{47}$ Vanuit grondwettelijk oogpunt blijft ook het beroep op een extra-constitutionele norm bovendien erg betwistbaar, omdat de Grondwet nu eenmaal integraal de uitoefening van de machten regelt. $4^{8}$

Het grondwetgevend decreet van het Nationaal Congres van I8 november 1830 dat de onafhankelijkheid van België proclameert, werd in het verleden vaak als een supra-constitutionele norm aangeduid, omdat het zich zelfs aan de grondwetgever zou opdringen en niet zou kunnen worden herzien. De hedendaagse auteurs zijn het er echter over eens dat er geen supra-grondwettelijke bepalingen bestaan en dat theoretisch elke grondwetsbepaling en elk grondwetgevend decreet van het Nationaal Congres kan worden herzien volgens de normale herzieningsprocedure van artikel 195 van de Grondwet. Aan de wetgevende Kamers kan immers niet het recht worden ontzegd om volgens de procedure voorzien in die bepaling de grondregels omtrent de inrichting van de Staat in heroverweging te nemen. ${ }^{49}$

Sommige auteurs hebben naar alternatieve grondslagen voor het voormelde advies en de voormelde conclusie gezocht. HuberLant verwijst naar "une hiérarchie entre les valeurs qui découle de la nature même des choses"..$^{\circ}$ Dumon stelt dat "zodra onze onafhankelijkheid, onze instellingen en onze grondwettelijke vrijheden door een vijand worden bedreigd echter aangepaste maatregelen nodig zijn om deze waarden te beschermen" en voegt daaraan toe: "Salus patriae suprema lex". ${ }^{\mathrm{I}}$ Die verklaringen bieden evenwel geen soelaas, aangezien zij zich even goed op het extra-constitutionele beroepen en op gespannen voet staan met artikel I87 van de Grondwet, dat net als negatie van het ciceroniaanse adagium werd opgevat (zie nr. 5).

"Invoeging van een transversale bepaling in de Grondwet over het afwijken van rechten en vrijheden", Parl. St. Kamer 2005-2006, nr. 5I-2304/oor, p. 70).

46 R. ERgec, "L'état de nécessité en droit constitutionnel belge", in Interuniversitair Centrum voor Staatsrecht (ed.), Le nouveau droit constitutionnel, Brussel, Bruylant, I987, 489; A. MAST en J. DuJARDIN, Overzicht van het Belgisch grondwettelijk recht, Gent, Story-Scientia, I98I, 489.

47 W.J. Ganshof van der Meersch en M. Diderich, "Les états d'exception et la Constitution belge", Ann. Dr. I953, 88.

48 J. Velaers en S. Van Drooghenbroeck, "Invoeging van een transversale bepaling in de Grondwet over het afwijken van rechten en vrijheden", Parl. St. Kamer 2005-2006, nr. 5I-2304/00I, p. 72.

49 Zie o.a. A. Alen en K. Muylle, Handboek van het Belgisch Staatsrecht, Mechelen, Kluwer, 20II, 235236; M.F. Rigaux, La théorie des limites matérielles à l'existence de la fonction constituante, Brussel, Larcier, I985, 55-60; A. Vanwelkenhuyzen, "Les limites du droit constitutionnel", in Rapports belges au XIIe C.I.D.C., Brussel, Bruylant, I988, II, 79-83. De Raad van State, afdeling Wetgeving, heeft zich bij die zienswijze aangesloten (advies van I5 juli I993, Parl. St. Kamer, I992-I993, nr. I036/2, p. 5). Ook in de praktijk werd reeds een "altijddurende" grondwetsbepaling herzien, meer bepaald artikel 85, dat vrouwen en hun nakomelingen "voor altijd" van de troonopvolging uitsloot.

50 C. Huberlant, "Etat de siège et légalité d'exception en Belgique", in Licéitéen droit positifet références légales aux valeurs, Brussel, Bruylant, I982, 426.

5 I F. Dumon, "Over enkele grondwettelijke problemen, gerezen tijdens de tweede wereldoorlog", Mededelingen van de Koninklijke Academie I983, 47. 
25. Het lijkt nochtans niet nodig om zich voor het funderen van het staatsnoodrecht ter vrijwaring van de onafhankelijkheid van het land op extra-constitutionele motieven te beroepen. Het lijkt mogelijk om het beginsel van de onafhankelijkheid een grondslag binnen de formele Grondwet te geven, meer bepaald in artikel I87 van de Grondwet zelf.

Uit de parlementaire voorbereiding van die bepaling blijkt immers dat de ideeën van Constant de grondwetgever hebben geïnspireerd. Zijn inzicht dat de staatsmachten hun bestaan te danken hebben aan de Grondwet, zodat zij deze niet kunnen schorsen, werd door VAN SNICK als ratio legis van die bepaling aangeduid (zie nr. 5). Welnu, indien de Staat zijn onafhankelijkheid verliest, impliceert dit meteen de meest verregaande schorsing van de Grondwet die denkbaar is, en wellicht zelfs de overtreffende trap van haar schorsing, zijnde haar afschaffing. In dergelijk geval kan geen enkele macht die door de Grondwet wordt toegewezen, nog volgens de Grondwet worden uitgeoefend. De staatsmachten hebben de plicht om de schorsing of de afschaffing van de Grondwet door buitenlandse usurpators tegen te gaan, aangezien die Grondwet de basis van hun bestaan en bevoegdheid uitmaakt. Indien de onafhankelijkheid van het land wordt bedreigd, en deze niet binnen het kader van de normale uitoefening van de bevoegdheden kan worden gevrijwaard, biedt artikel I87 van de Grondwet - dat overigens ook de grondslag van het continuïteitsbeginsel vormt $\mathrm{t}^{52}$ - de juridische basis om die onafhankelijkheid door middel van een abnormale bevoegdheidsuitoefening te vrijwaren.

In deze context kan ook artikel 33 van de Grondwet worden vermeld. Krachtens die hoeksteenbepaling gaan alle machten uit van de Natie en moeten zij worden uitgeoefend op de wijze bij de Grondwet bepaald. ${ }^{53}$ Welnu, bij een verlies van de onafhankelijkheid kan geen enkele macht nog worden uitgeoefend op de wijze bij de Grondwet bepaald. Ook deze bepaling verplicht de staatsmachten dus om de nodige maatregelen te nemen teneinde de onafhankelijkheid van het land te vrijwaren.

In die zin valt ook de doortocht van de Franse troepen zonder parlementaire instemming (zie nr. I5) op I2 augustus I83I grondwettelijk te rechtvaardigen: indien Koning Leopold I niet onmiddellijk de nodige maatregelen had genomen om het aanstormende Nederlandse leger te stuiten, dreigde het jonge België immers in strijd met de toenmalige artikelen I30 en 25 (thans de artikelen I87 en 33) van de Grondwet zijn prille onafhankelijkheid reeds opnieuw te moeten prijsgeven.

26. Die rechtvaardiging impliceert twee belangrijke beperkingen. Ten eerste kan noodrecht dat afwijkt van de Grondwet slechts een verantwoording vinden in die logica indien het beoogt noodtoestanden te bekampen die de onafhankelijkheid van het land in het gedrang brengen. Daarentegen kan noodrecht dat wordt ingezet om andere noodtoestanden te bekampen, geenszins op deze grondslag wor-

52 E. VAN Hooydonck, "Het artikel Izo van de Grondwet als algemene grondslag van het bestendigheidsbeginsel in het administratief recht", TBP I992, 82-86.

53 Zie hierover A. Alen, Hoe 'Belgisch' is het 'Belgische staatsrecht' nog?, Antwerpen, Intersentia, 2015, 6-I3. 
den aanvaard. Gelet op de algemene draagwijdte van artikel I87 van de Grondwet verdient deze uitzondering dus een restrictieve interpretatie. Binnenlandse onlusten zetten de onafhankelijkheid van het land niet op het spel en een afwijking van de normale werking der instellingen om dergelijke onlusten te bestrijden, vindt dus geen steun in het beginsel van de onafhankelijkheid.

Hetzelfde geldt voor terroristische activiteiten. Dergelijke activiteiten kunnen veel menselijk leed en een aanzienlijke materiële schade aanrichten en zij kunnen zelfs een maatschappij ontwrichten door ganse bevolkingsgroepen tegen elkaar op te zetten, maar hun gevolgen gaan - ongeacht de motieven van de terroristen - niet zo ver dat zij de onafhankelijkheid van de Staat op het spel zetten.

27. De tweede beperking heeft betrekking op de te nemen maatregelen. Zoals supra reeds werd aangegeven in verband met het beginsel van overmacht, biedt ook het beginsel van de onafhankelijkheid van het land slechts een rechtvaardiging voor schorsingen van de Grondwet die betrekking hebben op de werking van de instellingen. Daarentegen valt niet in te zien waarom ook grondrechten zouden moeten worden geschorst, nu een loutere beperking ervan kan volstaan (zie nr. I7). Dergelijke beperkingen moeten steeds evenredig zijn met de nagestreefde doelstelling, hetgeen door de bevoegde rechter moet kunnen worden getoetst, zij het desnoods pas op het ogenblik dat de onafhankelijkheid van het land niet meer op het spel staat.

28. In de huidige stand van het recht houdt enkel de besluitwet van II oktober I9I6 betreffende de staat van oorlog en de staat van beleg maatregelen in die de onafhankelijkheid van het land in geval van oorlog beogen te vrijwaren. Deze besluitwet wordt infra besproken (zie nr. 33), maar hier kan reeds worden aangestipt dat zij wel de eerste, maar niet de tweede voorwaarde eerbiedigt. De bijzondere bevoegdheden in deze besluitwet kunnen slechts worden uitgeoefend "met het doel 's lands verdediging en de belangen van het leger" te handhaven (artikel 4 , tweede lid, van de besluitwet van II oktober I9I6), hetgeen gelijk staat met het vrijwaren van de onafhankelijkheid. Maar de maatregelen die kunnen worden genomen, houden een dergelijk verregaand geheel van niet te rechtvaardigen beperkingen op de rechten en vrijheden van Titel II van de Grondwet in dat zij op een schorsing van die rechten en vrijheden neerkomen.

\section{I.2 Oorlog en staat van beleg}

29. De Grondwet bevat een aantal fundamentele regels over de gezagsuitoefening tijdens de staat van oorlog en over de gevolgen van de staat van oorlog op de werking van de Staat. Krachtens artikel I67, \$ I, tweede lid, van de Grondwet voert de Koning het bevel over de krijgsmacht en stelt Hij de staat van oorlog alsook het einde van de vijandelijkheden vast. Hij geeft daarvan kennis aan de Kamers, zodra het belang en de veiligheid van de Staat het toelaten, onder toevoeging van de passende mededelingen. In oorlogstijd mag geen herziening van de Grondwet worden ingezet of voortgezet. Dit verbod tot herziening van de Grondwet is eveneens van toepassing wanneer de Kamers verhinderd zijn bijeen te komen op het federale grondgebied (artikel rg6 van de Grondwet). Op die manier kan worden vermeden dat de Grondwet wordt herzien onder druk van oorlogsomstandigheden of tijdens een vijandige bezetting. Artikel I57, eerste lid, van de Grondwet voorziet 
in de mogelijkheid om militaire gerechten op te richten wanneer de in artikel I67 $_{7}$ bedoelde staat van oorlog is vastgesteld. Door de afschaffing van de militaire rechtbanken en het Militair Gerechtshof in vredestijd vallen de militairen in de regel onder de bevoegdheid van de gewone hoven en rechtbanken.

\section{a. De Koning heeft het bevel over de krijgsmacht}

30. De federale uitvoerende macht is bevoegd voor het defensiebeleid en voert het bevel over het leger. Ook als opperbevelhebber van het leger treedt de Koning niet op in persoonlijke naam, maar blijft hij onder de verantwoordelijkheid van de Regering (artikelen 88 en Io6 van de Grondwet). Voor de inzet van strijdkrachten is de Regering a posteriori verantwoording verschuldigd aan de Kamer van volksvertegenwoordigers. 54

Een belangrijk operationeel aspect van de verdediging van het grondgebied ontsnapt echter aan de bevelvoering van de Koning. Vreemde troepen mogen niet dan krachtens een wet tot de dienst van de Staat worden toegelaten, het grondgebied bezetten of er doorheen trekken (artikel I85 van de Grondwet). Voor de toelating van vreemde troepen tot het grondgebied is bijgevolg een wet vereist (zie evenwel nr. 25). Dit kan zowel een gewone wet zijn als een goedkeuringswet van een internationaal verdrag. Die wet kan de Koning machtigen om vreemde troepen de toestemming te verlenen om het grondgebied te bezetten, er zich op te stellen en er militaire activiteiten te ontplooien met hun uitrusting, hun materieel of hun wapens. De Koning moet daarbij de grenzen en voorwaarden eerbiedigen die de wetgever aan de machtiging heeft verbonden. ${ }^{55}$

3I. Artikel I67, § I, tweede lid, van de Grondwet verplicht de Koning de vaststelling van de staat van oorlog of het einde van de vijandelijkheden ter kennis te brengen van de Kamers. Ook het inzetten van strijdkrachten in het buitenland moet slechts achteraf door de Koning worden meegedeeld aan het Parlement. De federale uitvoerende macht moet haar beslissing bijgevolg niet voorafgaandelijk ter goedkeuring voorleggen aan de wetgevende macht..$^{56}$ De kennisgeving aan de Kamers kan eventueel worden uitgesteld indien het belang en de veiligheid van de Staat dit noodzakelijk maken.

Enkel indien de vaststelling van de staat van oorlog leidt tot een verdrag van bondgenootschap of indien het einde van de vijandelijkheden leidt tot een vredesverdrag, is de formele instemming van de Kamer van volksvertegenwoordigers vereist

54 K. Rimanque, De Grondwet. Toegelicht, gewikt en gewogen, Antwerpen-Groningen, Intersentia, I999, 336; M. VAN Damme, "De Grondwet en het inzetten van strijdkrachten. Een inleidende situering”, in A. De Becker, G. Laenen, M. Van Damme en E. Vandenbossche (eds.), De Grondwet en het inzetten van strijdkrachten, Antwerpen-Apeldoorn, Maklu, 2005, Io, nr. 2, noot 3.

55 J. Vande Lanotte, G. Goedertier, Y. Haeck, J. Goossens en T. De Pelsmaeker, Belgisch Publiekrecht, I, Brugge, die Keure, 2015, 888, noot I5; J. Velaers, De Grondwet en de Raad van State. Afdeling wetgeving, Antwerpen, Maklu, I999, 638-639.

56 Een loutere beraadslaging in de Ministerraad volstaat vanuit grondwettelijk oogpunt niet, omdat de Koning hiervan geen deel uitmaakt (zie nader: F. Dubuisson, "La participation de l'armée belge à l'opération 'force allié' de l'OTAN au Kosovo: questions au regard de l'article i67 de la Constitution", AP I/200I, 54 en de verwijzingen aldaar). 
voor het sluiten van het verdrag. ${ }^{57}$ Tijdens de parlementaire voorbereiding van de herziening van het vroegere artikel 68 (thans artikel I67) van de Grondwet werd specifiek aandacht besteed aan de hypothese van overmacht. Hiervan is sprake indien het land zich in staat van oorlog bevindt en de Kamer verhinderd is om bijeen te komen. In die buitengewone omstandigheden kunnen die verdragen onmiddellijk gevolg ressorteren, zelfs bij gebrek aan goedkeuring door de Kamer..$^{8}$

\section{b. De roep om het democratisch gehalte te verhogen}

32. De laatste decennia werd het Belgisch leger ingezet voor tal van militaire en vredesoperaties. In het verslag van de parlementaire onderzoekscommissie betreffende de gebeurtenissen in Rwanda wordt aan de Regering gevraagd om vaste regels en criteria vast te leggen voor de deelname van ons land aan toekomstige VN-vredesoperaties. ${ }^{59}$ De vraag naar een grotere inbreng van het Parlement wordt met grote regelmaat herhaald. ${ }^{60}$ Heel wat auteurs pleiten ervoor om de vaststelling van de staat van oorlog of het inzetten van het Belgische leger afhankelijk te maken van een voorafgaande consultatie of zelfs van een voorafgaande formele instemming vanwege de volksvertegenwoordiging: de Grondwet zou moeten aansluiten bij de globale Europese tendens tot het opwaarderen van de rol van de nationale wetgever. ${ }^{6 r}$

\section{c. De staat van oorlog en de staat van beleg}

33. De besluitwet van II oktober I9I6 houdt een gevoelige uitbreiding in van de bevoegdheden van de (federale) uitvoerende macht gedurende de staat van oorlog en de staat van beleg. Hoewel deze besluitwet werd uitgevaardigd tijdens de Eerste Wereldoorlog, oordeelde het Hof van Cassatie dat zij geen tijdelijke regeling

57 Op grond van artikel $167, \S 2$, van de Grondwet hebben verdragen immers eerst gevolg nadat ze de instemming van de Kamer van volksvertegenwoordigers hebben gekregen (J. VANDE LANOTTE, G. Goedertier, Y. Haeck, J. Goossens en T. De Pelsmaeker, Belgisch Publiekrecht, I, Brugge, die Keure, 2015, 735).

58 Verslag-Cerexhe, Parl. St. Senaat B.Z. I99I-I992, nr. Ioo-I6/2, p. Io: "Het moet evenwel worden vastgesteld dat bij overmacht, bijvoorbeeld wanneer het land zich in staat van oorlog bevindt, de verdragen bedoeld in het tweede lid van de voorgestelde tekst onmiddellijk gevolg hebben."

59 Verslag parlementaire onderzoekscommissie betreffende de gebeurtenissen in Rwanda, Parl. St., I997-98, nr. I/6II, Hoofdstuk V, Aanbeveling 7.

6o Zie recent nog T. VANDenput en L. VAN BIESEN, Voorstel van verklaring tot herziening van arti-

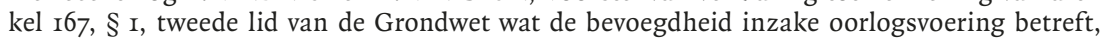
Parl. St., Kamer, 2015-2016, nr. 2065/oor.

6I Zie o.m. T. RuYs, "Kroniek van een nakende grondwetswijziging? Parlementaire controle op het inzetten van strijdkrachten in het buitenland", RW 2009-20I0, 514-530; M. VAN DAMME, "De Grondwet en het inzetten van strijdkrachten. Een inleidende situering", in A. De Becker, G. Laenen, M. Van Damme en E. Vandenbossche (eds.), De Grondwet en het inzetten van strijdkrachten, Antwerpen-Apeldoorn, Maklu, 2005, 22-25 (deze auteur vindt het argument dat de actieradius van de regering hierdoor in een internationaal overleg te zeer zou worden beperkt, niet overtuigend. Hij wijst er terecht op dat het overleg en de daaropvolgende inzet van de strijdkrachten toch enige tijd vraagt, zodat er ruimte is voor een parlementaire betrokkenheid); J. VelaErs en S. Van Drooghenbroeck, "Invoeging van een transversale bepaling in de Grondwet over het afwijken van rechten en vrijheden”, Parl. St. Kamer 2005-2006, nr. 5I-2304/ooI, p. 84. Naar Nederlands recht moet de regering in de regel de Staten-Generaal vooraf informeren dat zij van plan is de krijgsmacht in te zetten voor een deelname aan buitenlandse operaties (zie artikel roo Nederlandse Grondwet). 
inhoudt, maar een permanente regeling die automatisch van toepassing wordt in oorlogsomstandigheden. ${ }^{6}$

34. De besluitwet hanteert de noties "staat van oorlog", "tijd van oorlog" en "staat van beleg". De oorlogstijd is de periode gelegen tussen twee bij koninklijk besluit bepaalde data: de datum van mobilisatie van het leger en de datum waarop het leger op vredesvoet wordt teruggebracht. ${ }^{63}$ Deze definitie is schatplichtig aan artikel 58 van het Wetboek van militaire rechtspleging van ${ }_{5}$ juni I899, dat bepaalt dat voor de toepassing van de strafwetten en de inrichting van de rechtscolleges, de oorlogstijd aanvangt op de dag bepaald bij koninklijk besluit voor het mobiliseren van het leger en eindigt op de dag, eveneens bepaald bij koninklijk besluit, dat het leger terug op vredesvoet is gebracht. In de wet van I2 mei I927 op de militaire opeisingen wordt een onderscheid gemaakt tussen de opeisingen in vredestijd en in oorlogstijd. De oorlogstijd wordt er gelijkgesteld met de periode van de mobilisatie van het leger. ${ }^{6}$ Dit gebeurt eveneens in de eerste paragraaf van het enige artikel van de wet van 5 maart 1935 betreffende de staatsburgers die, bij vrijwillige dienstneming of bij opeising, in oorlogstijd de werking der openbare diensten moeten verzekeren en in artikel 4 van een wet van dezelfde datum betreffende de plichten van ambtenaren in oorlogstijd. Het begrip "staat van oorlog" of "oorlogstijd" is bijgevolg getransponeerd van de militaire strafwetten naar het geheel van de wetgeving. Op juridisch vlak zijn oorlogstijd en staat van oorlog synoniem. ${ }^{65}$

De omstandigheid dat de oorlogstijd niet start met het effectief intreden van de oorlog, wordt verklaard vanuit de verplichte neutraliteit die ons land werd opgelegd. De mobilisatie die start zodra de militairen die met verlof zijn, worden opgeroepen en die leidt tot het bijkomend versterken van strategische plaatsen, is een maatregel ter vrijwaring van de neutraliteit van het land en wil vermijden dat andere mogendheden het Belgische grondgebied als slagveld gebruiken. ${ }^{66}$

Gedurende de tijd van oorlog kan de Koning, na eensluidend advies van de Ministerraad, de "staat van beleg" uitspreken en opheffen. Het koninklijk besluit waarbij de staat van beleg uitgesproken of opgeheven wordt, duidt de gedeelten van het grondgebied aan waarop het toepasselijk is (artikel 2 besluitwet van II oktober I9I6). De staat van beleg bestaat dus niet van rechtswege, maar is het gevolg van een koninklijk besluit, op eensluidend advies van de Ministerraad. Bovendien kan

62 Cass. 4 maart i940, Pas. I946, I, 493, concl. Adv.-Gen. Hayoit de Termicourt.

63 K. Callebaut, "De staat van oorlog en de staat van beleg", TBP i959, 280.

64 Artikel 4 a van de wet van I2 mei I927 (BS 25 mei 1927) en artikel 66 van het Reglement over de militaire opeisingen dat werd vastgesteld bij KB van 3 mei I939 (BS Io september I939). Op grond van artikel 7 van de wet van I2 mei 1927 worden met de oorlogstijd gelijkgesteld de tijd waarin de troepen op mars zijn, samengetrokken worden of gekantonneerd liggen om te waken over 's land veiligheid op de grenzen, het vervullen van verplichtingen voortvloeiend uit internationale verdragen, de handhaving der orde en de uitvoering van de wetten. Die omstandigheden worden, in gemeen overleg, bepaald door de ministers van binnenlandse zaken en volksgezondheid en van landsverdediging, die de burgerlijke en militaire overheden daarvan ten gepaste tijde verwittigen.

65 K. Callebaut, "De staat van oorlog en de staat van beleg", TBP i959, 282; R. Ergec en S. Watthee, "Les dérogations aux droits constitutionnels", in M. Verdussen en N. Bonbled (eds.), Les droits constitutionnels en Belgique, Brussel, Bruylant, 20II, 397. 
de staat van beleg alleen bestaan in oorlogstijd. ${ }^{67}$ De fictieve staat van beleg die in sommige landen kan worden afgekondigd in vredestijd (zie nr. Io), is in België uitgesloten, en zou overigens in strijd zijn met artikel I87 van de Grondwet. ${ }^{68}$

35. Het leger moet niet feitelijk in staat van oorlog zijn om het op oorlogsvoet te brengen. Vlak voor beide Wereldoorlogen werd bij de dreiging van een nakende oorlog overgegaan tot de mobilisatie en duurde de oorlogstoestand langer dan de oorlogsverrichtingen. Na de Tweede Wereldoorlog werd het leger slechts bij Regentsbesluit van I juni 1949 terug op vredesvoet gebracht. ${ }^{69} \mathrm{Na}$ het einde van de Eerste Wereldoorlog viel de overheid terug op de besluitwet van II oktober I9I6 om de activisten en andere personen die misdrijven hadden gepleegd tegen de veiligheid van de Staat, door de militaire gerechten te laten berechten. Hetzelfde gebeurde na de Tweede Wereldoorlog om een snelle berechting van de collaborateurs mogelijk te maken. Dit oneigenlijk gebruik van het juridische begrip "staat van oorlog" wordt door HubERLANT fel bekritiseerd. Hij pleitte voor een wettelijke regeling die vastlegt wanneer de staat van oorlog een aanvang neemt en die zou moeten omschrijven wanneer deze toestand kan worden behouden..$^{\circ}$

\section{d. Gevolgen van de staat van oorlog en de staat van beleg ${ }^{71}$}

36. In geval van de staat van oorlog kan de Koning alle politiebevoegdheden uitoefenen en kan hij, indien nodig, deze bevoegdheid geheel of gedeeltelijk opdragen aan de provinciegouverneur of de arrondissementscommissarissen. Op grond van artikel 8, eerste lid, van de besluitwet van in oktober I9I6 is het verboden dagbladen, vlugschriften, geschriften, tekeningen of prenten uit te geven of, op welke wijze ook, in de openbare plaatsen of vergaderingen, bekendmakingen en inlichtingen te verspreiden die de vijand voordeel kunnen brengen of een ongelukkige invloed kunnen uitoefenen op de geest van de troepen en de bevolking. De besluitwet laat zelfs de instelling van een censuur toe, terwijl artikel 25 van de Grondwet uitdrukkelijk bepaalt dat de censuur nooit kan worden ingevoerd..$^{22}$ De overheden kunnen overgaan tot de opeising van personen en zaken om de werking van de openbare diensten te verzekeren (artikel Io, SI van de besluitwet van II oktober I9I6).

67 K. Callebaut, "De staat van oorlog en de staat van beleg”, TBP I959, 28I.

68 C. De Brouckère en F. Tielemans, Répertoire de l'administration et du droit administratif de la Belgique, $\mathrm{v}^{\circ}$ Force publique, t. VII, 456; O. Orban, Le droit constitutionnel de la Belgique, I, Luik, Dessain, I9o6, 335; J. Velaers en S. Van Drooghenbroeck, "Invoeging van een transversale bepaling in de Grondwet over het afwijken van rechten en vrijheden”, Parl. St. Kamer 2005-2006, nr. 5I-2304/00I, p. 68.

69 BS 5 juni i949.

70 C. Huberlant, "Etat de siège et légalité d'exception en Belgique", in Licéitéen droit positifet références légales aux valeurs, Brussel, Bruylant, $1982,424$.

$7 \mathrm{I}$ We beperken ons hier tot een summiere toelichting bij de gevolgen van deze uitzonderingstoestanden. Voor een grondig commentaar wordt verwezen naar W.J. GanSHOF VAN DER MeERSCH, Preadvies. De schorsing van de vrijheidsrechten in uitzonderingstoestand, in Vereniging voor de vergelijkende studie van het recht van België en Nederland Jaarboek III 1949-1950, Antwerpen, De Sikkel, Zwolle, W.E.J. Tjeenk Willink, 29-36.

72 Over de regeringscensuur in oorlogstijd: J. VeLAERs, De beperkingen van de vrijheid van meningsuiting, II, Antwerpen-Apeldoorn, Maklu, I99I, 797 e.v. 
De Koning kan op grond van de artikelen I, tweede lid, en 4 van de besluitwet, op eensluidend advies van de Ministerraad, aan de burgerlijke overheden of militaire overheden die hij aanwijst de bevoegdheid verlenen om zowel bij dag als bij nacht over te gaan tot huiszoekingen ${ }^{73}$ of tot een onderzoek aan het lichaam. ${ }^{74}$ Diezelfde overheden kunnen ook de bevoegdheid krijgen om de recidivisten, de vreemdelingen, de personen die verdacht worden contacten te hebben met de vijand en de personen die de krijgsverrichtingen hinderen, te verwijderen uit de plaatsen waar zij schadelijk zouden kunnen zijn (artikel 4 , eerste lid, $\mathrm{I}^{\circ}$ ), om de inlevering van de wapens en de munitie te bevelen door de "ambtenaren van rechterlijke politie" (artikel 4 , eerste lid, $3^{\circ}$ ), 75 om vergaderingen te beletten die van aard zijn om wanorde te verwekken of te onderhouden (artikel 4 , eerste lid, $4^{\circ}$ ), en om toezicht te houden op de correspondentie, ze te weerhouden of eventueel in beslag te nemen (artikel 4, eerste lid, $5^{\circ}$ ). De voorlaatste bevoegdheid strijdt met artikel 26 van de Grondwet, dat de Belgen het recht toekent om vreedzaam en ongewapend te vergaderen, mits zij zich gedragen naar de wetten, die de uitoefening van dit recht kunnen regelen. Het loutere risico dat de vergadering wanorde kan verwekken, volstaat volgens de besluitwet van II oktober igi6 nochtans om de vergadering zelfs preventief te verbieden..$^{6}$ De laatste bevoegdheid is in strijd met artikel 29 van de Grondwet, dat de onschendbaarheid van het briefgeheim waarborgt.

Deze bevoegdheden kunnen weliswaar slechts worden uitgeoefend "met als doel de verdediging van het land en de veiligheid van het leger te waarborgen" (artikel 4, tweede lid, van de besluitwet), zodat kan worden aangevoerd dat zij slechts van toepassing zijn wanneer de onafhankelijkheid van het land in het geding is (zie nr. 26). Niettemin houdt deze verregaande lijst van vrijheidsbeperkende maatregelen een dermate grote inbreuk op Titel II van de Grondwet in dat sprake is van een daadwerkelijke schorsing van de betrokken bepalingen. Nochtans rechtvaardigt het beginsel van de onafhankelijkheid van het land slechts schorsingen van de grondwetsbepalingen met betrekking tot de werking van de instellingen (zie nr. 27).

37. Indien bovendien ook de staat van beleg wordt afgekondigd, kunnen de politiebevoegdheden van de burgerlijke overheden zelfs worden uitgeoefend door de Minister van Oorlog of door de militaire overheden die de Koning daartoe aanduidt (artikel 3). Deze overdracht van bevoegdheden van de burgerlijke naar de militaire overheden met het oog op de handhaving van de orde is het wezenskenmerk van de staat van beleg.77 Die bevoegdheden hebben tevens betrekking op de voormelde beperkingen van grondrechten vermeld in artikel 4 van de besluitwet.

73 Artikel I5 van de Grondwet bepaalt weliswaar dat de woning onschendbaar is, maar laat vervolgens de wetgever toe om de gevallen en de vorm van de huiszoeking te bepalen.

74 Indien het gaat om een onderzoek aan het lichaam van een persoon van het vrouwelijk geslacht zal ertoe hetzij door een geneesheer, hetzij door een vrouw worden overgegaan (artikel 4, eerste lid, $2^{\circ}$, van de besluitwet van in oktober I9I6).

75 De besluitwet verleent in dit kader tevens een recht van "zoeking" en van inbeslagname.

76 J. Velaers, De beperkingen van de vrijheid van meningsuiting, II, Antwerpen-Apeldoorn, Maklu, I99I, 802 .

77 R. Ergec en S. Watthee, "Les dérogations aux droits constitutionnels", in M. Verdussen en N. Bonbled (eds.), Les droits constitutionnels en Belgique, Brussel, Bruylant, 20II, 398. 
38. De besluitwet van II oktober I9ı6 heeft kracht van wet (zie nr. 55) en kan dus niet door de gewone rechter aan de Grondwet worden getoetst. ${ }^{7}$ Zij werd genomen in een tijd waarin rechterlijke controle op formele wetgeving ondenkbaar was en werd nog niet toegepast sinds de oprichting van het Grondwettelijk Hof. Indien zich een nieuwe oorlogssituatie zou voordoen, zouden de vrijheidsbeperkingen waarin die besluitwet voorziet, wel langs prejudiciële weg aan het Grondwettelijk Hof kunnen worden voorgelegd. Wellicht zouden de meeste vrijheidsbeperkende maatregelen deze toetsing niet overleven.

\section{e. Het verklaren van de oorlog of het vaststellen van de staat van oorlog?}

39. Krachtens het oorspronkelijke artikel 68 van de Grondwet "verklaarde" de Koning de oorlog. Sinds de herziening van artikel I67, § I, tweede lid, van de Grondwet op 5 mei 1993 beperkt hij zich tot het "vaststellen" van de staat van oorlog. De grondwetgever wilde op die manier aansluiten bij de tendens in het internationaal recht om het gebruik van geweld bij internationale conflicten te veroordelen..$^{79}$ Die terminologische aanpassing strekt ertoe te beklemtonen dat België geen oorlogszuchtige natie is. ${ }^{80}$ Het was niet de bedoeling om aan het begrip "staat van oorlog" een andere inhoud te geven dan voorheen.

Bij de herziening in 2002 van artikel 157 van de Grondwet, dat in de mogelijkheid voorziet om militaire gerechten op te richten wanneer de staat van oorlog is vastgesteld, werd in het Parlement wel lang stilgestaan bij de juiste inhoud van de notie "het vaststellen van de staat van oorlog". Velaers en Van Drooghenbroeck verdedigen op grond van die parlementaire voorbereiding de stelling dat de beslissing van de Koning tot vaststelling van de staat van oorlog geen constitutief maar een declaratief karakter heeft. ${ }^{8 \mathrm{r}}$ Het instellen van de juridische staat van oorlog kan in die opvatting pas wanneer de Koning eerst een feitelijke staat van oorlog heeft vastgesteld.

Die interpretatie heeft ook gevolgen voor de besluitwet van II oktober I9I6. VeLAERS breekt een lans voor een grondwetsconforme interpretatie van de besluitwet, hetgeen onder meer tot gevolg heeft dat "de Koning het leger moet kunnen mobiliseren als een voorbereidende en bewarende maatregel zonder dat eerst de staat van oorlog zoals bepaald

78 Cass. 4 maart I940, Pas. I946, I, 493, concl. Adv.-Gen. Hayoit de Termicourt.

79 Parl. St. Kamer, I992-93, nr. 797/3, p. I4 en Parl. St. Senaat, BZ I99I-92, nr. Ioo-I6/I, p. 4.

80 J. Vande Lanotte, G. Goedertier, Y. Haeck, J. Goossens en T. De Pelsmaeker, Belgisch Publiekrecht, I, Brugge, die Keure, 2015, 734, noot 7.

8i J. Velaers en S. Van Drooghenbroeck, "Invoeging van een transversale bepaling in de Grondwet over het afwijken van rechten en vrijheden", Parl. St. Kamer 2005-2006, nr. 5I-2304/00I, p. 83. Zij baseren zich op het antwoord van de Minister van Justitie en van zijn medewerker op een vraag van kamerlid Pieters (Verslag-TalHaoui, Parl. St., Kamer, 2002-2003, nr. 50-I9I4/003, p. 9). Hierin staat onder meer te lezen dat "de minister van Justitie aanstipt dat het begrip 'staat van oorlog' een juridisch begrip is en dat verschillende voorwaarden moeten vervuld zijn alvorens de regering een dergelijk koninklijk besluit mag vaststellen". De medewerker van de Minister preciseerde "dat er een conflict kan bestaan als men op objectieve wijze vaststelt dat men wordt aangevallen of dat België als gevolg van zijn internationale verplichtingen bij een conflict betrokken is". Op vraag van kamerlid TALHAOUI verduidelijkt de medewerker van de minister dat "het hier om een objectief aspect gaat; zo nodig kan de staat van beleg worden afgekondigd bij een koninklijk besluit vastgesteld na overleg in Ministerraad". 
in de artikelen 157 , eerste lid, en $167, \S_{1}$, tweede lid, is vastgesteld". ${ }^{82}$ Indien deze visie juist is, betekent dit wel dat de grondwetgever in 2002 de draagwijdte van de notie "staat van oorlog" in artikel I67 van de Grondwet impliciet heeft herzien, terwijl die bepaling niet voor herziening vatbaar was. ${ }^{83}$

\section{f. Nood aan hervorming}

40. De regels die vervat liggen in de besluitwet van II oktober I9I6 lijken niet meer aangepast te zijn aan de huidige omstandigheden. ${ }^{84}$ De omstandigheid dat de gehanteerde terminologie voor een deel niet langer overeenstemt met de actuele inrichting van de Staat en van de politiediensten, is nog het minste kwaad. Zij is voornamelijk onaangepast in het licht van de technologische evoluties van de laatste eeuw, doordat zij te veel uitgaat van het beeld van de conventionele oorlog met grondtroepen. $\mathrm{Zij}$ houdt geen rekening met nieuwere vormen van oorlogsvoering, laat staan met het recente fenomeen van de cyberoorlog. Ook wat de mogelijke maatregelen betreft, is er ruimte voor een aanpassing aan modernere technieken van ideeënverspreiding, zoals de audiovisuele media en het internet.

Nog belangrijker is dat, door haar ongrondwettigheid, elke toekomstige toepassing van deze besluitwet precair is. We kunnen echter niet om de vaststelling heen dat de Belgische Grondwet, in tegenstelling tot de grondwetten van andere Europese landen, onvoldoende rekening houdt met de noden van de oorlogstijd. De vraag rijst of het niet de voorkeur verdient om de staat van oorlog als uitzonderingstoestand te regelen in de Grondwet (zie nr. 122). ${ }^{85}$ Hierbij moeten uiteraard de Europese en internationale mensenrechtenstandaarden en het internationaal humanitair recht als minimumstandaarden worden geëerbiedigd.

\section{I.3 Voorlopige conclusies}

4I. Brainich von Brainich Felth merkt op dat er in heel wat landen een sterke legalistische obstructie bestaat tegen het aanvaarden van ongeschreven staatsnoodrecht. ${ }^{86}$ Die tegenstand ligt in ons land vervat in de bewoordingen van artikel 187 van de Grondwet, die amper ruimte laten voor redenen om de Grondwet geheel

82 J. Velaers, "De Grondwet en de krijgsmacht", in A. De Becker, G. Laenen, M. Van Damme en E. Vandenbossche (eds.), De Grondwet en het inzetten van strijdkrachten, Antwerpen-Apeldoorn, Maklu, 2005, I27-I28.

83 In artikel I57, eerste lid, van de Grondwet wordt immers verwezen naar de vaststelling van de staat van oorlog zoals bedoeld in artikel I67, §I, tweede lid, van de Grondwet. Cfr. de zienswijze van kamerlid Pieters: "Derhalve strekt het tot aanbeveling de staat van oorlog te koppelen aan de in het Europees Verdrag vermelde oorlogstijd, veeleer dan aan een ander artikel van de Grondwet - te weten artikel 167 - dat niet voor herziening vatbaar is verklaard en waarvan de ervaring heeft geleerd dat het geen verband houdt met een feitelijke oorlogstoestand" (Parl. St., Kamer, 2002-2003, nr. 50-I9I4/003, p. Io). Zie voor een kritiek op de ongelukkige techniek van impliciete grondwetsherziening A. ALEN en F. Meersschaut, "De 'impliciete' herziening van de Grondwet”, in Présence du droit public et des droits de l'homme. Mélanges offerts à Jacques Velu, Brussel, Bruylant, I992, 26I-28I.

84 Zie reeds K. Callebaut, "De staat van oorlog en de staat van beleg”, TBP i959, 287.

85 In die zin W.J. Ganshof van der Meersch en M. Diderich, "Les états d'exception et la Constitution belge", Ann. Dr. I953, II7. Zie ook J. Velaers en S. VAN Drooghenbroeck, "Invoeging van een transversale bepaling in de Grondwet over het afwijken van rechten en vrijheden”, Parl. St. Kamer 2005-2006, nr. 5I-2304/oor, p. 73-74 en 93-94.

86 E.T. Brainich von Brainich Felth, Staatsnoodrecht, Zwolle, Tjeenk Willink, I993, 73. 
of gedeeltelijk te schorsen. Verreweg de meeste situaties die als "noodtoestand" kunnen worden bestempeld, kunnen naar Belgisch grondwettelijk recht niet worden bekampt met staatsnoodrecht. We hebben aangetoond dat de stelling van "de grondwet in vredestijd" moeilijk houdbaar is. En zelfs in oorlogstijd kan de Grondwet in beginsel niet worden geschorst.

Alleen wanneer er sprake is van werkelijke overmacht of wanneer de onafhankelijkheid van het land op het spel staat, kan tijdelijk worden afgeweken van de Grondwet. Dat slechts in die twee gevallen een gedeeltelijke schorsing van de Grondwet mogelijk is, onderstreept het absolute karakter van artikel I87 van de Grondwet, aangezien die twee uitzonderingen precies hun grondslag vinden in die bepaling. In geval van overmacht blijft de verplichting bestaan om de continuïteit van het landsbestuur te verzekeren, een verplichting die haar grondslag vindt in artikel I87 van de Grondwet. En indien de onafhankelijkheid van het land op het spel staat, moeten de staatsmachten in de eerste plaats verzekeren dat de algehele schorsing of zelfs afschaffing van de Grondwet waaraan zij hun bestaan ontlenen, wordt vermeden. In beide gevallen is het cruciaal dat de schorsing slechts zo lang duurt als strikt noodzakelijk en niet verder gaat dan nodig is om de voorliggende noodtoestand te bekampen. Alleen zo wordt vermeden dat de noodrechtopvatting die door artikel 187 van de Grondwet wordt afgewezen, langs een achterpoortje opnieuw ten tonele wordt gebracht.

Die tijdelijke schorsingen mogen bovendien slechts betrekking hebben op de grondwetsbepalingen die de normale werking van de instellingen regelen. In een rechtsstaat kan daarentegen niet worden aanvaard, zelfs niet in dergelijke situaties, dat het genot van bepaalde rechten en vrijheden wordt opgeschort. Een loutere beperking van bepaalde grondrechten, die steeds het voorwerp uitmaakt van rechterlijke controle, moet steeds volstaan. Zoals infra zal worden aangetoond, geschiedt die rechterlijke toetsing overigens terughoudender naargelang de ernst van de noodtoestand toeneemt.

42. De enige noodtoestand die omstandig in de Grondwet wordt geregeld, is de staat van oorlog. De prerogatieven van de Koning spelen in een dergelijke situatie een belangrijke rol, ten nadele van de democratische controle op het vaststellen ervan, op het beëindigen van de vijandelijkheden en op de oorlogshandelingen zelf. De besluitwet van II oktober I9I6 houdt een verdere machtsconcentratie bij de Koning of, na delegatie, bij het openbaar bestuur in. Indien de staat van beleg wordt afgekondigd, kan een deel van die bevoegdheden zelfs door de militaire overheden worden uitgeoefend. Verschillende van die bevoegdheden houden beperkingen van de rechten en vrijheden in die de hedendaagse grondwettigheidstoetsing niet zouden doorstaan. Het lijkt daarom aangewezen deze besluitwet te actualiseren en haar desnoods deels een grondwettelijk statuut te geven.

43. Hierna wordt kort geschetst hoe de Belgische wetgever en de rechtspraak in het verleden omgingen met noodtoestanden. Daaruit zal blijken dat artikel I87 van de Grondwet bijna steeds fungeerde als een rem op het gebruik van de theorie van het noodrecht. Voor een staatkundige praktijk of voor wetten die niet pasten binnen het strikte grondwettelijke kader werd niettemin steeds een creatieve verantwoording gezocht aan de hand van grondwettelijke principes. Alvorens die praktijk 
aan bod komt, moet evenwel worden onderzocht of de noodrechtbepalingen uit het supranationale recht een invloed uitoefenen op de ruime draagwijdte van artikel I87 van de Grondwet.

\section{De invloed van het internationale en Europese recht}

44. Slechts weinig staatsrechtelijke vraagstukken zijn nog vrij van internationale en supranationale invloeden. De dwingende invloed van de hogere rechtsnormen op alle wetgevende en uitvoerende handelingen laat zich in een meergelaagde rechtsorde tegelijkertijd voelen vanuit de nationale grondwetten en vanuit het Europese Unierecht, het EVRM en het internationale recht. ${ }^{87}$ Het staat in die meergelaagde rechtsorde aan de (grondwettelijke) rechter om regelgeving aan die veelheid van hogere normen te toetsen en daarbij zo veel als mogelijk onderlinge tegenstrijdigheden weg te werken aan de hand van een rechterlijke dialoog. ${ }^{88}$

Binnen het bestek van deze bijdrage kan niet in detail worden ingegaan op de verdragsrechtelijke bepalingen over de noodtoestand op zich. ${ }^{89}$ Er wordt slechts onderzocht in welke mate die verdragsbepalingen van invloed kunnen zijn op de wijze waarop de Belgische rechtsorde omgaat met noodsituaties. Daartoe moet eerst worden nagegaan hoe wetgeving aan het meergelaagde kader van hogere rechtsnormen wordt getoetst. Vervolgens wordt onderzocht welke rol de verdragsrechtelijke afwijkingsbepalingen kunnen spelen om het stilzwijgen van de Grondwet op te vullen.

\section{I Een meergelaagd toetsingskader}

45. Hoewel artikel I42 van de Grondwet het Grondwettelijk Hof geen bevoegdheid toekent om wetgeving rechtstreeks aan het internationale en Europese recht te toetsen, heeft het Hof twee technieken ontwikkeld om wetgeving onrechtstreeks aan die normen te toetsen, door hen in samenhang te lezen met normen waaraan het wel rechtstreeks mag toetsen. Die onrechtstreekse toetsingsnormen maken vaak de facto de werkelijke toetsingsnorm uit..$^{\circ}$

87 W. Van Gerven en S. Lierman, Algemeen deel. Veertig jaar later. Privaat- en publiekrecht in een meergelaagd kader van regelgeving, rechtsvorming en regeltoepassing, Mechelen, Kluwer, 20II, 2I-27.

88 Zie hierover M. CARTABia, "Europe and Rights: Taking Dialogue Seriously", EuConst 2009, 5-3I; L. GARLICKI, "The Cooperation of courts: the role of supranational jurisdictions in Europe", I-Con 2008, 509-530; C. VAN DE Heyning, "Grondwettelijke conversaties: een meerwaarde voor de bescherming van fundamentele rechten?", TBP 20I2, 395-4I9.

89 Zie S.R. Chowdhury, The Rule of Law in a State of Emergency: The Paris Minimum Standards of Human Rights Norms in a State of Emergency, New York, St. Martin's Press, I989; J.M. FitzPatrick, Human Rights in Crisis: The International System for Protecting Rights During States of Emergency, Philadelphia, University of Pennsylvania Press, I994; O. Gross and F. Ni Aolain, Law in Times of Crisis: Emergency Powers in Theory and Practice, Cambridge, Cambridge University Press, 2006; E. Hafner-Burton, L. Helfer en C. Fariss, "Emergency and Escape: Explaining Derogations from Human Rights Treaties", International Organization 20II, 673-707; J.P. Loof, Mensenrechten en staatsveiligheid: verenigbare grootheden? Opschorting en beperking van mensenrechtenbescherming tijdens noodtoestanden en andere situaties die de staatsveiligheid bedreigen, Nijmegen, Wolf Legal Publishers, 2005, 353-679; D. McGolDrICK, "The interface between public emergency powers and international law", I-CON 2004, 380-429.

90 Zie over deze technieken A. Alen en K. Muylle, Handboek van het Belgisch Staatsrecht, Mechelen, Kluwer, 20II, 52-54, 62-65, 497-50I en 523-528; A. Alen, J. Spreutels, E. Peremans en W. Verriddt, 
De eerste techniek, die bestaat sinds I989, hanteert als formele toetsingsnorm de artikelen io en II van de Grondwet, die het beginsel van gelijkheid en nietdiscriminatie waarborgen. Die bepalingen hebben, aldus het Grondwettelijk Hof, "een algemene draagwijdte. Zij verbieden elke discriminatie, ongeacht de oorsprong ervan: de grondwettelijke regels van de gelijkheid en de niet-discriminatie zijn toepasselijk ten aanzien van alle rechten en vrijheden, met inbegrip van die welke voortvloeien uit" de grondwetsbepalingen waaraan het Hof niet rechtstreeks mag toetsen,,$^{91}$ de algemene rechtsbeginselen ${ }^{92}$ en de bepalingen van internationaal en Europees recht. ${ }^{93}$ Wanneer het Hof toetst aan de artikelen ro en II van de Grondwet, in samenhang gelezen met mensenrechtenverdragen, betrekt het in zijn toetsing de inhoudelijke criteria volgens dewelke in die verdragen beperkingen mogelijk zijn. ${ }^{94}$

De tweede techniek, die bestaat sinds 2004, heeft betrekking op de analoge grondrechten. Het Grondwettelijk Hof is sinds 2003 bevoegd om wetgevende normen rechtstreeks te toetsen aan de grondrechten gewaarborgd in de artikelen 8-32, I70, I72 en I9I van de Grondwet. Aangezien de meeste van die grondrechten geheel of gedeeltelijk analoog zijn aan bepalingen in een of meer internationale en supranationale verdragen, maken die grondwets- en verdragsbepalingen een "onlosmakelijk geheel" uit en moet het Hof bij zijn toetsing aan de grondwettelijke rechten en vrijheden rekening houden met die internationale bepalingen. ${ }^{95}$

Deze technieken van samenlezing laten het Hof toe om de relevante rechtspraak van het Europees Hof voor de Rechten van de Mens en van het Hof van Justitie waarin het betrokken grondrecht wordt geïnterpreteerd, te vermelden én toe te passen. Zo kan het Hof aan de grondrechten in de Belgische Grondwet, waarvan de meeste nog van I83 I dateren, een evolutieve interpretatie geven, die hen in overeenstemming brengt met de hedendaagse interpretatie van de mensenrechtenverdragen. Bovendien eerbiedigt het Hof het beginsel van de ruimste rechtsbescherming en vermijdt het conflicten tussen zijn eigen rechtspraak en de rechtspraak van de Europese hoven. Tot slot maximaliseert het Hof de rechtsbescherming: een grondrecht dat zowel door de Grondwet als door een internationaal verdrag wordt gewaarborgd, kan slechts worden beperkt indien cumulatief is voldaan aan de formele beperkingsvoorwaarden in de Grondwet en aan de materiële beperkingsvoorwaarden in de mensenrechtenverdragen (zie nr. 9)..$^{6}$ Deze techniek van samenlezing waarborgt dus op tweevoudige wijze de ruimste rechts-

\footnotetext{
"Het Grondwettelijk Hof en het internationaal en Europees recht", TBP 2014, 6r9-652; G. Rosoux, Vers une 'dématérialisation' des droits fondamentaux? Convergence des droits fondamentaux dans une protection fragmentée, à la lumière du raisonnement du juge constitutionnel belge, Brussel, Bruylant, 20I6, 53-58 en $\mathrm{I} 35$-I 86 .

9I Vaste rechtspraak sinds GwH nr. 23/89, I3 oktober I989.

92 Vaste rechtspraak sinds GwH nr. 72/92, I8 november 1992.

93 Vaste rechtspraak sinds GwH nr. I8/90, 23 mei 1990.

94 GwH nr. I24/2000, 29 november 2000.

95 Vaste rechtspraak sinds GwH nr. I36/2004, 22 juli 2004. Indien de Grondwet geen bepaling bevat die analoog is aan een verdragsrecht, blijft de omweg via de artikelen io en II van de Grondwet vereist (GwH nr. 20/20I4, 29 januari 20I4).

96 Daarom kan een analoog grondrecht volgens het Hof slechts worden beperkt indien aan vier voorwaarden is voldaan: (i) de beperking is voorgeschreven door een voldoende precieze en toegankelijke formele wetsbepaling; (ii) zij beantwoordt aan een dwingende maatschappelijke behoefte; (iii) zij streeft een wettige doelstelling na; en (iv) de gevolgen van de beperking zijn evenredig met die doelstelling (GwH nr. 202/2004, 2I december 2004).
} 
bescherming, namelijk zowel op het vlak van de inhoudelijke waarborgen als op het vlak van de cumulatie van beperkingsvoorwaarden.

\subsection{De noodtoestand in de mensenrechtenverdragen}

\section{a. Draagwijdte van de internationaalrechtelijke noodrechtbepalingen}

46. Enkele belangrijke internationale en Europese mensenrechtenverdragen bevatten een uitdrukkelijke noodrechtbepaling. ${ }^{97}$ Dergelijke bepalingen lijken op het eerste gezicht moeilijk verzoenbaar met de wezenskenmerken van de mensenrechten, maar de opstellers van die verdragen beoogden hiermee vooral om de mogelijkheid om de noodtoestand uit te roepen, strikt te beperken, des te meer omdat gedurende een lange periode de uitzonderingstoestand de regel was geweest. Ook kunnen dergelijke bepalingen van aard zijn om potentiële verdragspartijen te overtuigen en de overheden een formeel kader te verschaffen om ernstige crisissen het hoofd te bieden..$^{8}$

Deze bepalingen lenen zich echter ook tot misbruik. Wanneer zij worden ingeroepen door stabiele democratieën met een sterke rechterlijke controle op het overheidshandelen, wordt daarmee vaak beoogd om de interne rechters aan te zetten tot een meer terughoudende toetsing van de genomen maatregelen. ${ }^{99}$ Ondemocratische regimes blijken dan weer vaak misbruik te maken van dergelijke bepalingen om hun macht te versterken en critici de mond te snoeren. ${ }^{\text {Ioo }}$

47. Deze internationale noodrechtbepalingen volgen grotendeels hetzelfde stramien. ${ }^{\text {Ior }}$ Ten eerste omschrijven zij op zeer restrictieve wijze welke situaties als noodtoestand in aanmerking komen: artikel I5 EVRM en artikel F van het Herziene Europees Sociaal Handvest vereisen een "tijd van oorlog" of "enige andere algemene noodtoestand, welke het bestaan van het volk bedreigt". Artikel 4 IVBPR vermeldt alleen die laatste hypothese, die niettemin ook oorlogen omvat, naast natuurrampen, gewelddadige opstanden, terrorisme en grote industriële ongevallen. ${ }^{\mathrm{I02}}$ Bijna alle gevallen waarin een lidstaat van de Raad van Europa succesvol beroep

97 Artikel 27 van de American Convention on Human Rights wordt niet besproken, aangezien dat verdrag België niet bindt. Het Handvest van de grondrechten van de Europese Unie, het Internationaal Verdrag inzake Economische, Sociale en Culturele Rechten en het VN-Verdrag voor de Rechten van het Kind bevatten geen gelijkaardige bepaling. Hieruit mag evenwel niet worden afgeleid dat niet van die verdragen kan worden afgeweken in geval van een noodtoestand (J. Velaers en S. Van Drooghenbroeck, "Invoeging van een transversale bepaling in de Grondwet over het afwijken van rechten en vrijheden”, Parl. St. Kamer 2005-2006, nr. 5I-2304/00I, p. 77-78).

98 B. Rosendorff en H. Milner, "The Optimal Design of International Trade Institutions: Uncertainty and Escape", International Organization 200I, 856.

99 E. Hafner-Burton, L. Helfer en C. Fariss, "Emergency and Escape: Explaining Derogations from Human Rights Treaties", International Organization 20II, 674-675.

Ioo M. NowAK, UN Covenant on Civil and Political Rights, 2nd revised edition, Kehl, Engel Verlag, 2005, 84 .

IOI Dit hoeft niet te verwonderen, aangezien artikel I5 EVRM gebaseerd is op het ontwerp van wat later artikel 4 IVBPR zou worden (B. VAN DER SLOOT, "Langs lijnen van geleidelijkheid: een jurisprudentieanalyse van artikel I5 EVRM", NTM/NJCM-Bulletin 20I2, 226).

IO2 D. McGoldRICK, "The interface between public emergency powers and international law", I-CON 2004, 393-395; M. NowaK, UN Covenant on Civil and Political Rights, 2nd revised edition, Kehl, Engel Verlag, 2005, 89-92; CCPR General Comment nr. 29 (72), 24 juli 200 I. 
deed op artikel I5 EVRM, hadden betrekking op terroristische aanslagen. ${ }^{103}$ In elk geval moet het gaan om zeer ernstige gebeurtenissen die de ganse bevolking of een groot deel ervan treffen en de organisatie van de samenleving zelf bedreigen. ${ }^{104}$ Die bedreiging moet actueel en imminent zijn, ${ }^{105}$ al neemt het belang van dat laatste criterium af, nu bij terroristische dreigingen de actualiteit van de dreiging minder omlijnd is dan bij oorlogssituaties, zodat de genomen noodmaatregelen een alsmaar langere duurtijd kennen. ${ }^{\text {106 }}$

Ten tweede dient de betrokken overheid de noodtoestand formeel uit te roepen en de bevoegde verdragsorganen daarvan op de hoogte te brengen. Die procedurele voorwaarde is door de opstellers van de verdragen opgevat als een conditio sine qua non, ${ }^{107}$ maar het EHRM en het Human Rights Committee van de Verenigde Naties stellen zich ter zake erg soepel op en aanvaarden soms zelfs een notificatie terwijl de betrokken maatregelen al jaren van toepassing zijn. ${ }^{\text {108 }}$

Ten derde worden bepaalde grondrechten uitdrukkelijk als notstandsfest bestempeld, zodat zelfs in geval van een noodtoestand er niet van mag worden afgeweken. De lijst in het EVRM is eerder beperkt: alleen de artikelen 2, 3, 4, eerste lid, en 7 EVRM worden op die manier beschermd. ${ }^{\text {Io9 }}$ Onder het IVBPR zijn de artikelen 6 , 7,8 , eerste en tweede lid, II, I5, I6 en I8 notstandsfest. ${ }^{\text {II }}$

Ten vierde moeten de genomen maatregelen die wel betrekking hebben op derogable rights, strikt beperkt zijn tot hetgeen de situatie vereist. Dit betekent dat de normale mogelijkheden en beperkingsclausules ontoereikend moeten zijn om aan de noodtoestand te remediëren, ${ }^{\text {III }}$ maar ook dat de duur, de geografische toepassing en de inhoud van de genomen maatregelen evenredig moeten zijn met de situatie die zich voordoet. ${ }^{\mathrm{II} 2}$ Dit impliceert dat geen enkel grondrecht waarvan

I03 R. ERgec, Les droits de l'homme à l'épreuve des circonstances exceptionnelles, Brussel, Bruylant, I987; I23-I70; S. SotTiaux, Terrorism and the Limitation of Rights. The ECHR and the US Constitution, Oxford, Hart Publishing, 2008, 49.

I04 EHRM I juli I96I, Lawless t. Ierland, $\$ 28$.

I05 EHRM 5 november ig69, Griekse zaak; O. De Schutter, "La Convention européenne des droits de l'homme à l'épreuve de la lutte contre le terrorisme”, in E. Bribosia en A. Weyembergh (eds.), Lutte contre le terrorisme et droits fondamentaux, Brussel, Bruylant, 2002, I26-I30; CCPR General Comment nr. 29 (72), 24 juli $200 I, \$ 3$.

Io6 B. VAN DER SLOOT, "Langs lijnen van geleidelijkheid: een jurisprudentieanalyse van artikel I5 EVRM", NTM/NJCM-Bulletin 20I2, 226.

I07 M. NowaK, UN Covenant on Civil and Political Rights, 2nd revised edition, Kehl, Engel Verlag, 2005, 92 en IOo-IOI; CCPR General Comment nr. 29 (72), 24 juli 2001, § 2.

Io8 Bvb. EHRM r juli I96I, Lawless t. Ierland; EHRM 25 mei I993, Brannigan en McBridet. Verenigd Koninkrijk.

Io9 Het gaat om het recht op leven (met uitzondering van geoorloofde oorlogshandelingen), het verbod van foltering of onmenselijke en vernederende behandeling of straf, het verbod van slavernij of dienstbaarheid en het strafrechtelijk wettigheidsbeginsel. Artikel 4.3 van het Zevende Protocol voegt daar ook het beginsel non bis in idem aan toe.

IIo Naast de grondrechten die ook in artikel I5 EVRM worden vermeld, gaat het om het verbod van gevangenisstraffen voor contractuele tekortkomingen, het recht op erkenning als persoon voor de wet, en de vrijheid van denken, geweten en godsdienst.

III EHRM 27 maart I962, De Becker t. België.

II 2 . NowAK, UN Covenant on Civil and Political Rights, 2nd revised edition, Kehl, Engel Verlag, 2005, 98; CCPR General Comment nr. 29 (72), 24 juli 200I, § 4. 
tijdelijk wordt afgeweken, volledig buiten werking wordt gesteld. ${ }^{113}$ De maatregelen die worden genomen om aan de noodtoestand te verhelpen, mogen bovendien geen spillover effect hebben, in de zin dat zij niet tevens mogen worden toegepast op situaties die buiten het kader van de noodtoestand vallen. ${ }^{114}$ Het evenredigheidsbeginsel laat verdergaande maatregelen toe naarmate de ernst van de dreiging toeneemt. ${ }^{15}$ In het algemeen geldt dat de lidstaten een ruime appreciatiemarge genieten, niet alleen inzake het bepalen van welke situaties het bestaan van het volk bedreigen, maar ook inzake het bepalen van de noodzakelijke maatregelen. ${ }^{\mathrm{I} 6}$

Ten vijfde moet de Staat die gebruikmaakt van deze afwijkingsbepalingen, zijn overige internationaalrechtelijke verplichtingen blijven eerbiedigen. Die verplichtingen moeten ruim worden opgevat, en hebben onder meer betrekking op de internationale mensenrechtenverdragen die een ruimere rechtsbescherming bieden, het internationaal humanitair recht, het ius cogens en het internationaal gewoonterecht. ${ }^{117}$ Artikel 4 IVBPR voegt daar nog aan toe dat de genomen maatregelen niet mogen discrimineren op grond van ras, huidskleur, geslacht, taal, godsdienst of maatschappelijke afkomst. Die laatste vereiste kan, wat het Europese mensenrechtensysteem betreft, uiteraard ook worden afgeleid uit artikel I4 EVRM. ${ }^{\mathrm{I} 8}$

\section{b. Is de overheid verplicht een noodtoestand te melden aan de bevoegde verdragsorganen?}

48. Hoewel de verdragsrechtelijke noodrechtbepalingen zeer restrictief zijn geformuleerd, hebben de soepele interpretatie en toepassing ervan door het Human Rights Committee en door het EHRM als gevolg dat die bepalingen alsmaar verder worden uitgehold. Die aanpak maakt dat het voor de beoordeling van de maatregelen die de betrokken lidstaat heeft genomen, maar weinig uitmaakt of zij al dan niet formeel een beroep op artikel 4 IVBPR of op artikel I5 EVRM heeft gedaan. In beide gevallen geldt immers dat de overheid over een zeer ruime appreciatiemarge beschikt om de nodige maatregelen te nemen teneinde een crisissituatie het hoofd te bieden. ${ }^{\text {I9 }}$

II3 D. McGoldrick, "The interface between public emergency powers and international law", I-CON 2004, 407-4I0.

II4 O. De Schutter, "La Convention européenne des droits de l'homme à l'épreuve de la lutte contre le terrorisme”, in E. Bribosia en A. Weyembergh (eds.), Lutte contre le terrorisme et droits fondamentaux, Brussel, Bruylant, 2002, I43-I46 en I48-I50.

II5 M. Nowak, UN Covenant on Civil and Political Rights, 2nd revised edition, Kehl, Engel Verlag, 2005, 97-98; S. SotTiaux, Terrorism and the Limitation of Rights. The ECHR and the US Constitution, Oxford, Hart Publishing, 2008, $5 \mathrm{I}$.

II6 EHRM i8 december I996, Aksoy t. Turkije; B. VAN DER SLoot, "Langs lijnen van geleidelijkheid: een jurisprudentieanalyse van artikel I5 EVRM", NTM/NJCM-Bulletin 20I2, 210-2I3.

II7 R. ERGEC, Les droits de l'homme à l'épreuve des circonstances exceptionnelles, Brussel, Bruylant, I987, 223227; M. NowAK, UN Covenant on Civil and Political Rights, 2nd revised edition, Kehl, Engel Verlag, 2005, 99; CCPR General Comment nr. 29 (72), 24 juli $200 I$, § I2.

ir8 O. De Schutter, "La Convention européenne des droits de l'homme à l'épreuve de la lutte contre le terrorisme", in E. Bribosia en A. WeYembergh (eds.), Lutte contre le terrorisme et droits fondamentaux, Brussel, Bruylant, 2002, I46-I48.

II9 B. VAN DER SLOOT, "Langs lijnen van geleidelijkheid: een jurisprudentieanalyse van artikel I5 EVRM", NTM/NJCM-Bulletin 20I2, 2I3-2I8; F. VANNESTE, "Het Europese Hof voor de Rechten van de Mens en de overheden die terrorisme bestrijden: brothers in arms?", RW 2003-2004, I674-I675. 
ERGEC betoogt nochtans dat de Belgische overheid in geval van een noodtoestand niettemin verplicht is om artikel I5 EVRM toe te passen door middel van een formele kennisgeving aan de Secretaris-Generaal van de Raad van Europa. Zo niet zouden de Belgische rechters, gelet op de directe werking van artikel I5 EVRM, immers moeten weigeren om wettelijke en andere maatregelen toe te passen die de grondrechten te sterk inperken. ${ }^{120}$

Intussen heeft het EHRM evenwel duidelijk gemaakt dat het hoe dan ook rekening zal houden met de algemene context van de noodtoestand, ongeacht of die noodtoestand al dan niet formeel werd afgekondigd, aangezien die noodsituatie een cruciale rol speelt in de evenredigheidstoets. ${ }^{\text {I2I }}$ De Belgische rechters die geroepen worden om artikel I5 EVRM toe te passen, dienen zich voor de interpretatie van die bepaling te richten naar de Straatsburgse rechtspraak, en kunnen bijgevolg aan een louter gebrek aan kennisgeving van een noodtoestand aan de SecretarisGeneraal van de Raad van Europa geen rechtsgevolgen verbinden.

\section{c. Mag de Belgische overheid zich beroepen op de verdragsrechtelijke noodrechtbepalingen?}

49. De vraag rijst zelfs of het de Belgische overheden wel toegestaan is om, gelet op het relatieve stilzwijgen van de Grondwet inzake de noodtoestand en het grondwettelijke verbod om de Grondwet geheel of gedeeltelijk te schorsen, een beroep te doen op artikel I5 EVRM en artikel 4 IVBPR. Volgens toenmalig AdvocaatGeneraal bij het Hof van Cassatie VeLu verhindert artikel 53 EVRM (vroeger artikel 6o EVRM) dat een Staat waarvan de grondwet geen noodtoestand kent, toch de noodtoestand uitroept op grond van die verdragsbepalingen. ${ }^{122}$

Die stelling wordt tegengesproken door ERGEC, die argumenteert dat overmacht en het inroepen van de noodtoestand algemene rechtsbeginselen zijn, zodat het uitroepen van de noodtoestand wel degelijk een internrechtelijke grondslag heeft en artikel 53 EVRM dus niet van toepassing is. ${ }^{123}$

I20 R. Ergec, Les droits de l'homme à l'épreuve des circonstances exceptionnelles, Brussel, Bruylant, I987, 348; id., "L'état de nécessité en droit constitutionnel belge", in CIDP/ICSR (ed.), Le nouveau droit constitutionnel, Brussel, Bruylant, I987, r69-170.

I2I EHRM 29 november I988, Brogan t. Verenigd Koninkrijk, $\$ 48$.

I22 Concl. Adv.-Gen. J. Velu bij Cass. 23 september I976, Pas. I977, I, 88. Zie in dezelfde zin J. VANDE LanotTe en Y. Haeck, Handboek EVRM, 2.II, Antwerpen, Intersentia, 2005, I94-I95; J. Velaers, De beperkingen van de vrijheid van meningsuiting, II, Antwerpen-Apeldoorn, Maklu, I99I, 96I; J. VelaErs en S. Van Drooghenbroeck, "Invoeging van een transversale bepaling in de Grondwet over het afwijken van rechten en vrijheden”, Parl. St. Kamer 2005-2006, nr. 5I-2304/00I, p. 76.

I23 R. ERGEC, Les droits de l'homme à l'épreuve des circonstances exceptionnelles, Brussel, Bruylant, I987, 94; id., "L'état de nécessité en droit constitutionnel belge", in CIDP/ICSR (ed.), Le nouveau droit constitutionnel, Brussel, Bruylant, I987, I69. 
50. Die laatste opvatting kent een te beperkte draagwijdte toe aan artikel 187 van de Grondwet, ${ }^{124}$ dat elke schorsing van de Grondwet verbiedt (zie nr. 8). Artikel I87 van de Grondwet verhindert volgens ons wel degelijk dat de Belgische overheid toepassing maakt van artikel I5 EVRM of van artikel 4 IVBPR om de werking van bepaalde grondrechten op te schorten. Dit volgt uit de hierboven beschreven vaststelling dat de grondwettelijke en verdragsrechtelijke grondrechten een "onlosmakelijk geheel" vormen (zie nr. 45) en, zoals Velu terecht aanhaalt, uit het beginsel van de ruimste rechtsbescherming, dat is verankerd in artikel 53 EVRM.

Het Grondwettelijk Hof heeft reeds verduidelijkt dat zijn samenlezende grondrechtentoetsing zowel betrekking heeft op de inhoudelijke waarborgen van de respectieve grondwets- en verdragsbepalingen als op de beperkingscriteria. ${ }^{125}$ Bijgevolg moeten ook artikel I87 van de Grondwet, enerzijds, en de artikelen I5 EVRM en 4 IVBPR, anderzijds, met elkaar in verband worden gebracht. Artikel I87 van de Grondwet biedt in dit opzicht een ruimere rechtsbescherming dan beide verdragsbepalingen, aangezien het de opschorting van grondrechten, ongeacht het bestaan van een noodtoestand, verbiedt, terwijl de artikelen I5 EVRM en 4 IVBPR die mogelijkheid slechts aan voorwaarden onderwerpen.

Bijgevolg mogen de Belgische overheden noodtoestanden weliswaar bestrijden door grondrechten te beperken op grond van de gebruikelijke criteria waarin de Grondwet en de internationale verdragen voorzien, maar mogen zij de grondrechten nooit opschorten, zelfs niet in geval van een noodtoestand.

5I. De onmogelijkheid om grondrechten op te schorten impliceert overigens dat elk overheidsoptreden, ook wanneer het beoogt een noodtoestand te verhelpen, ter toetsing kan worden voorgelegd aan een onafhankelijke en onpartijdige rechter. De Belgische overheden kunnen immers ook het recht op toegang tot de rechter, zoals dat wordt gewaarborgd door de analoge grondrechten neergelegd in artikel I3 van de Grondwet en artikel 6 EVRM, ${ }^{126}$ niet opschorten.

\subsection{Besluit}

52. Uit het voorgaande blijkt dat artikel I87 van de Grondwet niet alleen de ontkenning van de internrechtelijke noodtoestand inhoudt, maar dat die bepaling ook als gevolg heeft dat de Belgische overheid geen beroep kan doen op artikel I5 EVRM of op artikel 4 IVBPR. Dit maakt de overheid nochtans niet machteloos in het bekampen van noodtoestanden. In het volgende hoofdstuk wordt nagegaan hoe de Belgische instellingen in het verleden zijn omgegaan met noodtoestanden zonder daarbij formeel de noodtoestand uit te roepen of de grondrechten op te schorten.

I24 ERGEC beperkt die draagwijdte ten onrechte tot de specifieke historische context waarin artikel 187 van de Grondwet tot stand kwam, en die betrekking had op een staatsgreep (zie nr. 6). Bijgevolg zou die bepaling niet van toepassing zijn op schorsingen van de Grondwet die onvrijwillig plaatsvinden, omdat zij door noodsituaties worden ingegeven (ibid., I67-I68).

I25 GwH 2I december 2002, nr. 202/2004; GwH I9 juli 2005, nr. I3I/2005; GwH I8 oktober 2006, nr. I5I/2006; GwH 27 november 2008, nr. 170/2008; GwH I8 maart 20I0, nr. 29/2010; A. Alen en K. MuYLle, Handboek van het Belgisch Staatsrecht, Mechelen, Kluwer, $2011,526$.

I26 GwH 3 december 2009, nr. 195/2009. 


\section{$3 \quad$ Feitelijke omgang met noodtoestanden}

53. In de vorige hoofdstukken werd vastgesteld dat de Belgische Grondwet amper ruimte biedt voor gehele of gedeeltelijke schorsingen van de Grondwet. Enkel in geval van werkelijke overmacht of indien de onafhankelijkheid van het land in het gedrang is, is een afwijking van de grondwetsbepalingen met betrekking tot de werking van de instellingen mogelijk. Een schorsing van de grondwettelijke rechten en vrijheden is daarentegen nooit mogelijk. Aan dat beletsel kan niet worden ontkomen door beroep te doen op artikel I5 EVRM of artikel 4 IVBPR.

Nochtans doen zich in de praktijk wel degelijk noodtoestanden voor. In België hadden die crisissituaties doorgaans, maar niet steeds, betrekking op oorlogssituaties. Wanneer de nood het hoogst was, werden creatieve technieken aangewend om hieraan te verhelpen en werd gezocht naar een manier om die technieken binnen het bestaande grondwettelijke kader te verantwoorden. We bespreken hieronder achtereenvolgens de besluitwetten en de buitengewone machtenwetten, die betrekking hadden op oorlogssituaties, en de bijzondere machtenwetten, die in het verleden voor allerhande crisissituaties werden aangewend. Vervolgens wordt gefocust op de belangrijkste hedendaagse noodtoestand, namelijk de terroristische dreiging. Aan de hand van de rechtspraak van het Grondwettelijk Hof en het EHRM wordt onderzocht welke ruimte de rechter aan de overheden biedt om aan dergelijke dreigingen het hoofd te bieden.

\section{I Besluitwetten}

\section{a. De besluitwetten van Le Havre (Eerste Wereldoorlog)}

54. Vanaf oktober I9I4 zag de regering-de Brocqueville zich verplicht om uit te wijken naar Saint-Adresse, nabij Le Havre, om van daaruit de strijd voort te zetten samen met de troepen die zich in België achter de rivier De IJzer hadden teruggetrokken. Het bijeenroepen van het Parlement was niet mogelijk omdat de Duitse troepen het grootste deel van het Belgische grondgebied bezet hielden. In die omstandigheden kon de wetgevende macht niet meer functioneren zoals wordt voorgeschreven door de Grondwet. Krachtens artikel 26 (thans artikel 36) van de Grondwet wordt de wetgevende macht immers gezamenlijk uitgeoefend door de Koning, de Kamer van volksvertegenwoordigers en de Senaat. De onmogelijkheid voor het Parlement om bijeen te komen in de periode van oktober I9I4 tot november I9I8 had tot gevolg dat de wetgevende macht werd uitgeoefend door de enige overgebleven tak: de Koning en de in raad verenigde Ministers. De Koning oefende als enig orgaan de wetgevende macht uit door middel van besluitwetten, waarin in de aanhef werd gewezen op de onmogelijkheid om de wetgevende Kamers bijeen te roepen en op de behandeling van de besluitwetten in de Ministerraad. ${ }^{127}$

I27 In het verslag aan de Koning bij de eerste in IgI4 genomen besluitwetten staat het volgende te lezen: "Onder de dwang der omstandigheden is de Grondwet zo niet geschorst, dan toch onuitvoerbaar in zekere harer bepalingen; de wetgevende macht namelijk kan naar de grondwettelijke voorschriften niet meer functioneren. In de onmogelijkheid waarin men zich bevindt het Parlement bijeen te roepen kan slechts één tak van de wetgevende macht handelend optreden: de Koning. Voor de aangelegenheden waar de tussenkomst van de wetgevende macht vereist is, blijft er dan ook geen andere oplossing over dan aan de Koning de zorg over 
De besluitwetten werden afgekondigd en met 's Lands zegel bekleed en door de regering in Le Havre in het Belgisch Staatsblad bekendgemaakt. ${ }^{.28}$

55. De geldigheid van de besluitwetten werd na de Eerste Wereldoorlog door het Hof van Cassatie erkend in een arrest van II februari igI9. Het Hof oordeelde dat de Koning, met toepassing van de grondwettelijke beginselen, als enige werkzaam gebleven tak van de wetgevende macht en onder de verantwoordelijkheid van zijn ministers door middel van besluitwetten de beschikkingen had kunnen nemen die noodzakelijk waren voor de verdediging van het grondgebied en voor de vitale belangen van het land. ${ }^{\mathrm{I} 29}$ Deze besluitwetten moeten dus als formele wetten worden beschouwd en kunnen bijgevolg slechts bij wet worden gewijzigd. Zij zijn tevens onttrokken aan de grondwettigheidstoetsing door de gewone rechter; enkel het Grondwettelijk Hof is bevoegd om ze aan de Grondwet te toetsen.

De conclusie van procureur-generaal TerLinden ligt in de lijn van het arrest. $\mathrm{Na}$ erop te hebben gewezen dat de soevereiniteit van België niet werd geschorst en dat een Natie een wetgevende macht veronderstelt, wijst hij erop dat het noodzakelijk was om koste wat kost wetgevend te kunnen optreden: "Il faut, comme on pourra, en s'écartant le moins possible des prescriptions légales, parer aux brutales nécessités de l'heure. (...). Le Roi, le troisième délégué était là. Il n'y avait plus pour représenter le pays que lui, lui seul. (...). Loin d'avoir violé la Constitution, le Roi l'a, au contraire, appliquée dans la mesure du possible et dans son esprit, comme l'eussent fait les Constituants." I3o Anders dan het Hof van Cassatie maakt de procureur-generaal toepassing van de theorie van de overmacht en van het noodrecht: "Une loi - Constitution ou loi ordinaire - ne statue donc jamais que pour des périodes normales - pour celles qu'elle peut prévoir. Euvre de l'homme, elle est soumise comme toutes les choses humaines, à la force des choses, à la force majeure, à la nécessité."

De zienswijze van het Hof van Cassatie wordt op een nog krachtiger wijze verwoord in een arrest van 4 maart I940 waarin staat te lezen dat de wetgevende macht zich in dergelijke omstandigheden op grond van artikel 26 van de Grondwet van 1831 (thans artikel 36 ) concentreert in het enige orgaan dat nog kan handelen. ${ }^{\mathrm{I}{ }^{\mathrm{I}}}$

56. De opvatting dat de besluitwetten van Le Havre met toepassing van de grondwettelijke beginselen of op grond van artikel 26 van de Grondwet van I83I werden genomen, kan een aantal auteurs niet overtuigen. VAUTHIER is van oordeel dat de stelling van het Hof van Cassatie niet houdbaar is, omdat ze ingaat tegen de duidelijke tekst van deze grondwetsbepaling, waaruit niet kan worden afgeleid dat de Koning alleen de wetgevende macht kan uitoefenen. Quid immers indien de Koning in de onmogelijkheid zou zijn om zijn bevoegdheden uit te oefenen, bijvoorbeeld

te laten zelf de nodige bepalingen te treffen" (Verslag aan de Koning betreffende de besluitwetten van 26 december I9I4, BS 25-3I december I9I4).

I28 S. HoRvat, De vervolging van militairrechtelijke delicten tijdens wereldoorlog I. De werking van het Belgisch krijgsgerecht, Brussel, VUBPRESS, 2009, 88.

I29 Cass. II februari I9I9, Pas. I9I9, I, 9, concl. Proc.-gen. Terlinden.

I30 Conclusie Proc.-gen. M. Terlinden bij Cass. Ir februari I9I9, Pas., I9I9, I3.

I3I Cass. 4 maart I940, Pas., I946, 493, concl. Adv.-gen. Hayoit de Termicourt. 
in geval van gevangenschap? ${ }^{132}$ In die hypothese is het volgens VAUTHIER denkbaar dat een groep van representatieve personen (ministers, volksvertegenwoordigers, senatoren of hogere officieren) die bekleed zijn met een moreel gezag, als wetgever kan optreden in naam van het Belgische volk. Bij erkenning van hun gezag door het niet-bezette deel van het land en door andere Staten hebben we te maken met een pouvoir de fait die ook een legitieme macht uitmaakt (pouvoir de droit) omdat de legitimiteit van de feitelijke macht steunt op het permanente karakter van de nationale soevereiniteit. Volgens VAUTHIER steunde de uitoefening van de wetgevende macht door de Koning tijdens de Eerste Wereldoorlog niet op grondwettelijke principes, maar op algemene rechtsbeginselen van het publiekrecht en van het internationaal recht.

57. Ook Wodon zocht een andere juridische grondslag voor de besluitwetten van Le Havre. Hij ontwikkelde de theorie van de "Prééminence royale", die een cruciale betekenis toekent aan de Koning in zijn hoedanigheid van Staatshoofd. De Koning is immers niet alleen het hoofd van de uitvoerende macht en een van de drie takken die samen de wetgevende macht vormen, maar is tevens als Staatshoofd verplicht de onafhankelijkheid van het land te handhaven en de integriteit van het grondgebied te bewaren. Die opdracht van het Staatshoofd steunt op de grondwettelijke eed die de Koning aflegt voor de verenigde Kamers (artikel 8o, thans artikel 9I, van de Grondwet). ${ }^{\mathrm{I} 33}$ De stelling van Wodon kon niet op bijval rekenen, vooreerst omdat de plicht om de onafhankelijkheid van het land te handhaven, niet is vervat in de eedformule, maar in het decreet van het Nationaal Congres van I8 november 1830 met betrekking tot de onafhankelijkheid van België (zie nr. 23) of in artikel I87 van de Grondwet zelf (zie nr. 25). Uit de eedformule kan overigens niet worden afgeleid dat de Koning een persoonlijke macht, laat staan de overhand op de andere staatsmachten, zou krijgen in oorlogsomstandigheden. De artikelen 88 en ro6 van de Grondwet laten niet toe dat de Koning zelf een beleid zou kunnen voeren zonder medewerking of verantwoordelijkheid van zijn ministers. ${ }^{134}$

58. De pogingen van VAUTHIER en Wodon lijken overigens onnodig. Zoals blijkt uit de conclusie van procureur-generaal TerLINDEN biedt het bestaan van overmacht een verantwoording en uit de arresten van het Hof van Cassatie van II februari I9I9 en van 4 maart I940 blijkt dat de besluitwetten een verantwoording vinden in het beginsel van de continuïteit en in de noodzaak om het grondgebied - en dus 's lands onafhankelijkheid - te verdedigen. Aldus wordt een afwijking van de grondwetsbepalingen met betrekking tot de normale werking van de instellingen gerechtvaardigd zonder het kader van artikel I87 van de Grondwet te verlaten (zie nrs. I6 en 25).

I32 Rev.adm., I9I9, 202. Het is R. OcKrent die de naam van de anonieme annotator in de Revue de l'administration bekendmaakte. OcKrent zelf hanteert de idee van de "Prééminence nationale" als verantwoording voor de besluitwetten van Le Havre (zie Les crises constitutionnelles du Pouvoir législatifen Belgique. Les pouvoirs des Sécretaires généraux sous l'occupation ennemie, Brussel, I945, 22 en 26).

I33 L. Wodon, "Considérations sur la séparation et la délégation des pouvoirs en droit public belge", in Bulletin Académie royale de Belgique. Classe des sciences politiques et morales, I942, 55 en "Sur le rôle du Roi comme chef de l'Etat dans les cas de défaillances constitutionnelles”, in Bulletin Académie royale de Belgique. Classe des Lettres, sciences politiques et morales, I94I, boek XXVII, 2 I2 e.v.

I34 J. De Meyer, "Over de legitimiteit van de besluitwetten van de oorlogsregeringen in I9I4-I9I8 en in I940-I944”, in Liber Amicorum A. De Schrijuer, Gent, I968, 299. 


\section{b. De besluitwetten van Londen (Tweede Wereldoorlog)}

59. Door de capitulatie van het Belgische leger op 28 mei 1940 ontstond er een conflict tussen de Koning en de regering-Pierlot, die in ballingschap ging in Londen en de strijd wilde verderzetten. Aangezien de Koning in krijgsgevangenschap was en onder huisarrest stond in het kasteel te Laken, was de regering van oordeel dat zij door een analoge toepassing van artikel 79 (thans artikel 90) van de Grondwet, in samenhang gelezen met de artikelen 26 en 82 (thans de artikelen 36 en 93) van die Grondwet, de wetgevende en de uitvoerende macht kon uitoefenen. Artikel 82 van de Grondwet van I83I luidt als volgt: "Indien de Koning in de onmogelijkheid verkeert te regeren, roepen de ministers, na deze onmogelijkheid te hebben laten vaststellen, de Kamers dadelijk bijeen. Door de verenigde Kamers wordt in de voogdij en het Regentschap voorzien." Op grond van artikel 79, derde lid, van de Grondwet van I83I wordt de grondwettelijke macht van de Koning in naam van het Belgische volk uitgeoefend door de in raad verenigde ministers en onder hun verantwoordelijkheid te rekenen "van het overlijden van de Koning en tot de eedaflegging van zijn troonopvolger of van de Regent". De regering zag zich geconfronteerd met maar liefst drie buitengewone omstandigheden: vooreerst de onmogelijkheid van de Koning om te regeren en vervolgens de onmogelijkheid om de Kamers bijeen te roepen, hetgeen tot gevolg had dat er niet onmiddellijk een Regent kon worden benoemd.

6o. Door de lange duur van de Tweede Wereldoorlog konden de in raad verenigde ministers uiteindelijk de uitvoerende en de wetgevende macht uitoefenen van 28 mei 1940 tot 20 september 1944 . Slechts na de bevrijding konden de Kamers opnieuw worden samengeroepen. Op 20 september 1944 hebben de verenigde kamers bij decreet Prins Karel, de jongere broer van de Koning, verkozen tot Regent. Hij oefende dan de machten uit die bij de Grondwet aan de Koning zijn toegekend. ${ }^{135}$

6I. Het Hof van Cassatie bevestigde de rechtsgeldigheid van die juridische constructie. In een arrest van II december 1944 oordeelde het Hof dat de in raad verenigde Ministers, door een logische toepassing te maken van de artikelen 79 en 82 (thans de artikelen 90 en 93) van de Grondwet, de grondwettelijke macht van de Koning en dienvolgens van de wetgevende macht hebben uitgeoefend om de voor de verdediging van het grondgebied en de door 's Lands vitale belangen vereiste maatregelen te nemen in de periode tussen de dag waarop de Koning in de onmogelijkheid verkeerde om te regeren en de dag waarop de bevrijding van het grondgebied het de Kamers mogelijk heeft gemaakt om bijeen te komen en in het regentschap te voorzien. ${ }^{\mathrm{r}}{ }^{6}$ De in artikel 82 (thans artikel 93) van de Grondwet

I35 Door de Koningskwestie kon Koning Leopold III zijn functie niet onmiddellijk opnemen. Vermits artikel 82 (thans artikel 93) van de Grondwet niet bepaalt wanneer het Regentschap een einde neemt, diende de regering een wetsontwerp in om die beslissing over te laten aan de verenigde wetgevende Kamers. De wet van rg juli 1945 bepaalt dat de Koning de uitoefening van zijn grondwettelijke machten slechts hervat na een beraadslaging van de verenigde Kamers, vaststellend dat de onmogelijkheid te regeren een einde heeft genomen (BS 3 augustus 1945). Ter uitvoering van deze wet hebben de verenigde Kamers het decreet gestemd van 20 juli I950, waarbij zij vaststellen dat de onmogelijkheid te regeren van Koning Leopold III een einde heeft genomen (BS 2I juli I950). De Koningskwestie leidde uiteindelijk tot de troonsafstand van Leopold III.

I36 Cass. II december 1944, Arr. Verbr., I945, 6 o. 
bedoelde onmogelijkheid om te regeren, werd van toepassing geacht in geval van gevangenschap van het Staatshoofd.

Ook ten aanzien van deze besluitwetten, die de in raad verenigde ministers ter uitvoering van de artikelen 79 en 82 van de Grondwet van I83I hebben vastgesteld, heeft het Hof van Cassatie later geoordeeld dat zij de waarde van wetten in de formele zin hebben. ${ }^{\mathrm{I} 37}$

62. Sommige auteurs maken een voorbehoud bij de uitlegging van artikel 82 van de Grondwet van I83 I door het Hof van Cassatie, omdat de grondwetgever enkel de hypothese voor ogen had van een geestesziekte die het de Koning voor onbepaalde tijd zou onmogelijk maken om zijn taak naar behoren te vervullen..$^{13^{8}}$ Een tekstargument ondersteunt deze opvatting. De ministers moeten de onmogelijkheid (de psychische toestand) laten vaststellen, maar zijn zelf onmachtig om die vaststelling te doen. ${ }^{139}$ Hoewel Wigny spreekt over een "gedurfde" interpretatie, heeft het Hof van Cassatie in elk geval de letter en de geest van de Grondwet geëerbiedigd met de analoge toepassing van artikel 82 van de Grondwet van I83I. ${ }^{\text {I40 }}$ Men mag immers niet uit het oog verliezen dat die grondwetsbepaling niet specifiek de geestesziekte van de Koning vermeldt, maar de "onmogelijkheid om te regeren" hanteert als algemene notie. Het beginsel van de continuïteit van de openbare dienst geldt a fortiori voor de staatsmachten, omdat de voortzetting van hun werking zich des te meer opdringt. Een interpretatie van de Grondwet in het licht van het beginsel van de continuïteit van de staatsmachten verdient de voorkeur. ${ }^{\mathrm{I} I \mathrm{I}}$

\section{c. Aan de overkant van de Maas: ongeschreven staatsnoodrecht als verantwoording voor "wetsbesluiten"}

63. In Nederland was tijdens de Tweede Wereldoorlog de gezamenlijke uitoefening van de wetgevende macht door de Kroon en de Staten-Generaal niet mogelijk. Vanuit formeel oogpunt kon de wetgevende macht door het vertrek van koningin Wilhelmina en haar ministers naar Londen en door de bezetting van het grondgebied door de Duitse troepen niet meer gezamenlijk uitgeoefend worden. Er werden bijgevolg vanuit Londen "wetsbesluiten" genomen die de vorm hadden van een koninklijk besluit. De Hoge Raad bevestigde in een arrest van 30 oktober 1946 dat

I37 Cass. I8 oktober 1949, Arr. Verbr. I950, 54.

I38 R. Ockrent, Les crises constitutionnelles du Pouvoir législatif en Belgique. Les pouvoirs des Sécretaires généraux sous l'occupation ennemie, Brussel, I945, I07-I08. De neuropsychiatrische aandoening van de Engelse Koning George III en de constitutionele problemen die hierdoor ontstonden, waren de inspiratiebron van deze grondwetsbepaling (A. Alen en K. Muylle, Handboek van het Belgisch Staatsrecht, Mechelen, Kluwer, 20II, I4I; W.J. Ganshof van der Meersch, "Enkele juridische aspecten van de actie der regering tijdens de oorlog I940-I944", in Liber Amicorum A. De Schrijuer, Gent, I968, 393-394).

I39 R. Ockrent, Les crises constitutionnelles du Pouvoir législatif en Belgique. Les pouvoirs des Sécretaires généraux sous l'occupation ennemie, Brussel, I945, I08: "C'est la nécessité de cette appréciation qui a vraisemblabement inspiré aux Constituants la sagesse de ne pas la confier aux ministres du Roi, afin de rendre impossible une révolution de palais qui consisterait pour les ministres à constater par eux-mêmes, abusivement, l'impossibilité où se trouverait le Roi de régner."

I40 P. Wigny, Droit constitutionnel. Principes et droit positif, I, Brussel, Bruylant, I952, 204.

I4I F. Dumon, "Over enkele grondwettelijke problemen, gerezen tijdens de tweede wereldoorlog", in Academia Analectica, 1983,29 en de noot 73. 
de wetsbesluiten in de plaats konden treden van wetten in de formele zin en dat ze als regels gebaseerd op staatsnoodrecht na de Tweede Wereldoorlog geen formeel wettelijke bekrachtiging behoefden. ${ }^{142}$

64. Niet de Grondwet maar het subjectieve staatsnoodrecht gaf de Nederlandse regering de bevoegdheid om in nood wetsbesluiten te treffen die afwijken van het voor normale omstandigheden geldende recht voor zover deze maatregelen geboden kunnen zijn ter bescherming van de haar toevertrouwde belangen. De Hoge Raad overwoog dat "de Kroon alsdan bevoegd is tot het uitvaardigen van maatregelen van wetgeving voor zover zulks, zonder dat het herstel van de samenwerking tussen de Kroon en de Staten-Generaal kan worden afgewacht, door de omstandigheden geboden is". Indien de overheid beslist dat het uitvaardigen van wetgevende maatregelen door buitengewone omstandigheden geboden is, treedt ze op grond van een discretionaire bevoegdheid op. Bijgevolg vermag de rechter slechts aan een wetsbesluit verbindende kracht te ontzeggen voor zover die gebodenheid niet aanwezig kan zijn geweest. De toetsing blijft met andere woorden beperkt tot de marginale redelijkheidstoets omdat de bestuurlijke beleids- en beoordelingsvrijheid moet worden gevrijwaard. ${ }^{143} \mathrm{Er}$ is verder geen ruimte voor een doorgedreven doelmatigheidsbeoordeling van de noodmaatregel.

65. Anders dan het Hof van Cassatie aanvaardt de Hoge Raad dus dat ongeschreven staatsnoodrecht een grondslag kan bieden voor de afwijking van de Grondwet. De vraag rijst waarom het Hof van Cassatie de voorkeur gaf aan een verantwoording die werd "ingepast" in de Belgische Grondwet. Een plausibele verklaring lijkt te zijn dat het adagium "Nood breekt wet" blijkbaar niet op kan tegen het voorschrift van artikel I87 van de Grondwet, dat elke schorsing van de Grondwet verbiedt. Het bestaan van ongeschreven staatsnoodrecht wordt niet aanvaard, omdat artikel I87 van de Grondwet een uiting is van een doorgedreven legalisme. Het recht dat de werking van de staatsmachten beheerst, is vanuit Belgisch perspectief bij uitsluiting te vinden in de Grondwet en in de geschreven wet. Door dit legalistisch standpunt is er geen ruimte voor ongeschreven recht dat indruist tegen de Grondwet. ${ }^{\text {I44 }}$

\subsection{Buitengewone machtenwetten}

\section{a. Ontstaansgeschiedenis}

66. Net voor het uitbreken van de Tweede Wereldoorlog verleende de wet van 7 september 1939 de Koning buitengewone machten voor de duur dat het leger op voet van oorlog verkeerde. ${ }^{145}$ De uitvoerende macht werd gemachtigd om in noodzakelijke en spoedeisende gevallen bij in Minsterraad overlegd koninklijk besluit

I42 H.R. 30 oktober I946, NJ I946, 737, conclusie Adv.- Gen. Rombach en noot D.J.V.; E.T. Brainich VON Brainich Felth, Staatsnoodrecht, Zwolle, Tjeenk Willink, I993, 75-76.

I43 S. DaniëLs, "Commentaar op artikel 103 van de Grondwet", in E.M.H. Hirsch Ballin en G. LeenKNEGT (ed.), Artikelsgewijs commentaar op de Grondwet, webeditie 2016 (www.Nederlandrechtstaat.nl), 9-IO.

I44 Zie algemeen over de bezwaren van het legisme tegen het staatsnoodrecht: E.T. BRAINICH VON Brainich Felth, Staatsnoodrecht, Zwolle, Tjeenk Willink, I993, 7I-76.

I45 BS 8 september 1939 . 
"wetskrachtige" bepalingen aan te nemen met het oog op de veiligheid en de verdediging van het grondgebied en het Rijk, de handhaving van de openbare rust, de werking van het gerecht en de rechtsmachten, het bestuur van de provinciën en de gemeenten en van ondergeschikte besturen, de volksgezondheid, het krediet, de ravitaillering en de economische en financiële belangen van het land en de bevolking. ${ }^{146}$ De regering verkreeg tevens buitengewone machten op fiscaal vlak en kon afwijken van alle bepalingen betreffende de inkomsten en uitgaven van de Staat. ${ }^{\text {I4 }}$

Het toekennen van buitengewone machten aan de Koning werd in de memorie van toelichting als volgt verantwoord: "De ernstige internationale gebeurtenissen die zich pas hebben voorgedaan maken het verlenen noodzakelijk van een bijzondere uitgebreide macht aan de Koning met het oog op het verzekeren van's Lands buitenlandse en binnenlandse veiligheid, de verdediging van het Rijk, de handhaving van de openbare orde, de ravitaillering, de vrijwaring van het Land, de economische en financiële belangen van land en bevolking." ${ }^{4} 8$

Aan de regering-Pierlot werden bijgevolg in 1939 buitengewone machten verleend waarvan de duur werd bepaald door de duur zelf van de gebeurtenissen, welke de aanvraag ervan rechtvaardigden. De macht verschoof op ingrijpende wijze van het Parlement naar de regering totdat het leger bij koninklijk besluit opnieuw op vredesvoet zou worden gebracht. ${ }^{\mathrm{I} 9}$

67. Kort na de bevrijding van het land verkreeg de regering opnieuw buitengewone machten omdat België samen met de geallieerden de strijd wilde verderzetten tot de capitulatie van Nazi-Duitsland. De uitvoerende macht argumenteerde dat het noodzakelijk was om de in de wet van 7 september 1939 verleende machten aan te vullen teneinde het land in staat te stellen op doeltreffende wijze deel te nemen aan de oorlogsinspanningen van de "Verenigde Volkeren" en om het hoofd te bieden aan de noodwendigheden van het nationale leven. De wet van 7 september 1939 werd bijgevolg aangevuld en bevestigd door de buitengewone machtenwet van I4 december $1944 .{ }^{150}$ Door een wet van 20 maart 1945 werden aan de Koning opnieuw - ditmaal voor een beperkte duur van zes maanden - buitengewone machten toegekend. ${ }^{51}$ In totaal werden $4 \mathrm{I} 2$ besluiten uitgevaardigd op grond van de wet van 7 september 1939 en I02 besluiten op grond van de wet van 20 maart I945.

I46 Er werd aangenomen dat de notie "nood en spoed" feitelijke begrippen zijn die uitsluitend ter beoordeling van de Koning staan. Aan dit "formele" vereiste zou zijn voldaan van zodra in de aanhef van het buitengewone machtenbesluit werd vastgesteld dat de voorgestelde maatregelen noodzakelijk en spoedeisend zijn. Zie Cass., I3 november 1946, Pas. 1947, 4II; K. Mees, Preadvies betreffende delegatie van wetgevende bevoegdheid, VVSRBN (ed.), Zwolle, W.E.J. Tjeenk Willink, I963, I3.

I47 Artikel I van de wet van 7 september 1939.

I48 Parl. St. Kamer, $2^{\mathrm{e}}$ BZ I939, nr. I7, p. I.

I49 De tijd van oorlog neemt een aanvang op de door het koninklijk besluit betreffende de mobilisatie van het leger vastgestelde dag en eindigt op de door het koninklijk besluit betreffende het terugbrengen van het leger op voet van vrede bepaalde dag.

I50 De tekst van beide buitengewone machtenwetten werd gecoördineerd bij het Regentsbesluit van 24 januari 1945 tot samenschakeling van de wetten van 7 september 1939 en I4 december 1944 . Het Regentsbesluit werd gepubliceerd in het Belgisch Staatsblad van 26 januari 1945. De wet van 7 september 1939 werd nog gewijzigd door de wet van Io maart 1947 (BS 24-25 maart 1947).

I5I BS 24 maart I945. 


\section{b. Een belangrijk gradatieverschil}

68. De wetten op de buitengewone machten hanteren een gelijkaardige techniek als de bijzondere machtenwetten (zie nrs. 77 e.v.), maar er zijn enkele belangrijke verschillen. ${ }^{152}$ Vooreerst moet worden opgemerkt dat het verlenen van buitengewone machten altijd verband hield met oorlogsomstandigheden. Het "buitengewone" karakter houdt dus verband met de uitzonderlijke dreiging die oorlogsomstandigheden inhouden voor het voortbestaan van het land. Die uitzonderlijke situatie verklaart waarom het Parlement, anders dan bij het verlenen van bijzondere machten, zich akkoord verklaart met een machtigingswet die veel ruimer is en die een buitengewone (want bijna volledige) bevoegdheidstoewijzing aan de Koning inhoudt. ${ }^{153}$ De buitengewone toestand is zodanig dat volgens de inschatting van het Parlement een ruime beleidsvrijheid voor de Koning onvermijdelijk is. Het exceptionele karakter verklaart eveneens dat de termijn waarvoor buitengewone machten werden verleend, langer is dan bij een bijzondere machtenwet.

\section{c. De "oneigenlijke besluitwetten"}

69. De koninklijke besluiten die steunen op de wetten houdende toekenning van buitengewone machten, werden in het verleden vaak besluitwetten genoemd. Ze verschillen echter ingrijpend van de besluitwetten van Le Havre en Londen, die wetten in formele zin zijn. Men kan de besluiten die werden genomen met toepassing van de wetten op de buitengewone machten derhalve slechts als "oneigenlijke besluitwetten" kwalificeren. ${ }^{154}$ De grondwettigheid van een oneigenlijke besluitwet kan niet worden getoetst door het Grondwettelijk Hof, omdat het geen wet is in de formele zin. ${ }^{155} \mathrm{Zij}$ valt daarentegen wel onder het rechterlijk wettigheidstoezicht op grond van artikel 159 van de Grondwet, al heeft het Hof van Cassatie dat toezicht afgezwakt (zie nr. 7I).

\section{d. Juridische grondslag}

70. De meeste auteurs zijn van oordeel dat een buitengewone machtenwet net als een bijzondere machtenwet (zie nr. 88) haar grondslag vindt in artikel Io5 van de Grondwet. ${ }^{156}$ Die stelling impliceert dat artikel I05 van de Grondwet een erg

I52 A. Alen en K. Muylle, Handboek van het Belgisch Staatsrecht, Mechelen, Kluwer, 20II, 73I.

153 K. Mees, Preadvies betreffende delegatie van wetgevende bevoegdheid, VVSRBN (ed.), Zwolle, W.E.J. Tjeenk Willink, I963, I4.

I54 A. Alen en K. Muylde, Handboek van het Belgisch Staatsrecht, Mechelen, Kluwer, 73I; C. Behrendt, "Excursion à l'orée de la chasse gardée du juge constitutionnel", Rev. Fac. Dr. Liège 2007, 544; A. Mast, J. Dujardin, M. Van Damme en J. Vande Lanotte, Overzicht van het Belgisch Administratief recht, Mechelen, Kluwer, 20I2, 27; Verslag Philippart, Parl. St. Kamer, I944-45, nr. 74, p. 8.

I55 Anders GwH nr. 136/2003, 22 oktober 2003. Zie ook GwH nr. 72/2002, 2 april 2002, waarin werd geoordeeld dat de prejudiciële vraag klaarblijkelijk niet behoorde tot de bevoegdheid van het Hof om een andere reden dan de onbevoegdheid wat betreft de te toetsen norm (in casu de besluitwet van 29 december 1945). Er wordt aangenomen dat het arrest van 22 oktober 2003 dat betrekking heeft op de besluitwet van 29 december 1945 berust op een vergissing en geen principiële draagwijdte heeft (A. Alen en K. Muylle, Handboek van het Belgisch Staatsrecht, Mechelen, Kluwer, 20II, 73I, noot 8).

I56 A. Alen en K. Muylle, Handboek van het Belgisch Staatsrecht, Mechelen, Kluwer, 20II, 734; F. DeLpérée, Le droit constitutionnel de la Belgique, Brussel, Bruylant, 2000, 777; A. Mast en J. Dujardin, 
flexibele tekst is, omdat de omvang en de duur van de bevoegdheidstoewijzing aan de Koning kunnen variëren in functie van de omstandigheden die eraan ten grondslag liggen. Slechts indien de onafhankelijkheid van het land in het gedrang komt, is er plaats voor de ingrijpende bevoegdheidsverschuiving die het gevolg is van het verlenen van buitengewone machten en die de facto tot gevolg heeft dat de Kamers worden uitgeschakeld als wetgever voor de duur van de buitengewone machten. ${ }^{157}$

In zoverre een beroep op artikel I05 van de Grondwet niet volstaat, vinden de buitengewone machtenwetten, gelet op de reden waarom zij in het leven werden geroepen, hun verantwoording in artikel I87 van de Grondwet zelf, veeleer dan op gespannen voet met die bepaling te staan. De staatsmachten zijn immers verplicht de onafhankelijkheid van het land te vrijwaren, zelfs indien zulks een tijdelijke afwijking van de grondwetsbepalingen inzake de werking van de instellingen met zich meebrengt (zie nr. 25).

\section{e. Rechtsaard en toetsing van buitengewone machtenbesluiten}

7I. Uit de parlementaire bespreking in de Senaat blijkt duidelijk dat er bij de totstandkoming van de wet van 7 september 1939 een belangrijke strekking was die de Koning wilde toelaten om wetten in formele zin te maken, net alsof het Parlement zich in de materiële onmogelijkheid bevond om bijeen te komen. Het verslag van senator Ronse deed in dit verband een beroep op de theorie van de noodtoestand. ${ }^{158}$

Het Hof van Cassatie oordeelde echter dat de wet van 7 september 1939 de Koning niet de wetgevende macht heeft toegekend en dat hem alleen in zijn hoedanigheid van hoofd van de uitvoerende macht buitengewone machten werden verleend. De besluiten die genomen werden op grond van deze wet, zijn bijgevolg akten van de uitvoerende macht en geen wetten in de formele zin. Het Hof van Cassatie is de zienswijze van de Bijzondere Senaatscommissie terecht niet bijgetreden, omdat ze nu eenmaal op ernstige grondwettelijke bezwaren stuit. ${ }^{159}$

Door te bepalen dat de besluiten van de Koning kracht van wet hebben, heeft de wetgever ze volgens het arrest van het Hof van Cassatie van 27 januari 1943 niettemin in zekere mate onttrokken aan de wettigheidstoetsing van artikel I59 van de

Overzicht van het Belgisch Grondwettelijk Recht, Gent, Story-Scientia, I983, 227. Anders R. Ockrent, Les crises constitutionnelles du Pouvoir législatifen Belgique. Les pouvoirs des Secrétaires généraux sous l'occupation ennemie, Brussel, I945, 42.

I57 K. MeEs, Preadvies betreffende delegatie van wetgevende bevoegdheid, VVSRBN (ed.), Zwolle, W.E.J. Tjeenk Willink, I963, I4.

I58 Verslag-Ronse, Parl. St., Senaat, BZ I939 (2), nr. I3, p. 3: "Wij zegden reeds hooger dat de nieuwe te stemmen wetgeving de regeering zal habiliteeren om beschikkingen te treffen die werkelijk besluitwetten zijn. Dit heeft 0.m. als gevolg dat artikel 107 [thans artikel 159] van de Grondwet op hen niet van toepassing zal zijn." Zie ook p. 5: "Kan het betwist worden dat ons land zich op dit ogenblik in een staat van nood bevindt? Ware het niet te eng te beweren dat er slechts een materieele onmogelijkheid bestaat wanneer het Parlement verhinderd is naar Brussel of een andere stad te komen?"

I59 Zie in dit verband: G. Dor, noot onder Cass. 27 januari I943, RJDA, I946, (9), I2: "On s'explique, dès lors, fort bien que le magistrat ne tienne pas compte des opinions formulées dans des documents ou des discours nettement inconciliables avec les principes fondamentaux de la Constitution." 
Grondwet. ${ }^{160}$ De hoven en rechtbanken zijn immers niet bevoegd om te oordelen over de overeenstemming van die besluiten met de Grondwet en de wetten, tenzij dan met de wet zelf waarbij buitengewone machten aan de Koning werden verleend.

72. De justitiële rechter beschikt - net als bij bijzondere machtenbesluiten - wel over de macht om na te gaan of de besluiten binnen de perken blijven van de machtigingswet en is verplicht om de toepassing ervan te weigeren indien dit niet het geval is. De grenzen van de machtigingswet zijn bij een buitengewone machtenwet echter vager dan bij een bijzondere machtenwet. ${ }^{\text {.6I }}$ In tal van arresten heeft het Hof van Cassatie onderzocht of de besluiten die steunden op de wetten houdende toekenning van buitengewone machten binnen de perken bleven van de machtigingswet. ${ }^{162}$ Omwille van de ruime omschrijving van de doeleinden waarvoor de machtiging werd verleend in de wet van 7 september 1939, zullen de buitengewone machtenbesluiten zo goed als steeds stroken met de machtigingswet.

De betwisting die aanleiding gaf tot het arrest van het Hof van Cassatie van 8 oktober 1985 , bevat hiervan een mooie illustratie. In die zaak rees de vraag of de "oneigenlijke besluitwet" van 29 december 1945 genomen werd overeenkomstig een van de doelstellingen van de wet van 7 september $1939 .{ }^{163}$ Het bijzondere machtenbesluit van 29 december 1945 verbiedt elk opschrift of aanplakking op andere plaatsen dan die welke door de gemeenteoverheden tot aanplakking zijn bestemd of door de eigenaar of de gebruiksgerechtigde vooraf en schriftelijk werden vergund. De eiser tot cassatie voerde aan dat die bepaling in dergelijke algemene bewoordingen is gesteld dat haar toepassingsgebied zich niet beperkt tot opschriften en aanplakkingen die de openbare rust verstoren. Dit voorschrift zou derhalve de perken overschrijden die door de machtigingswet worden gesteld, namelijk het verzekeren van de openbare rust. Het Hof oordeelde evenwel dat artikel I, $2^{\circ}$, van de wet van 7 september 1939 de Koning toelaat wetskrachtige beschikkingen te treffen om de openbare rust te verzekeren en dat het besluit werd ingegeven door "het rustverstorend karakter van het stelselmatig (wanordelijk) aanbrengen van opschriften ongeacht de inhoud ervan". Bijgevolg gaat het besluit de perken van de machtigingswet niet te buiten. Het Hof merkt tevens op dat de rechter de gepastheid van een besluit genomen binnen het raam van de wet niet vermag te betwisten zonder zich de rechten van de uitvoerende macht aan te matigen.

I6o Cass. 27 januari I943, RJDA I946, 5, noot G. Dor; Pas. I943, I, 32. Het Hof oordeelde in dit arrest dat de besluiten, indien ze genomen worden binnen de perken van de verleende machtiging en volgens de voorziene formaliteiten (beraadslaging in de Ministerraad), genieten van een onweerlegbaar vermoeden van overeenstemming met de wet en de Grondwet. Zie tevens Cass. I3 november I946, RJDA I946, 67, noot D. Decleire; Pas. I946, I, 4II; Cass., 27 februari i947, Pas. I947, I, II8; Cass., 28 november 1955, Pas. 1956, I, 295; Cass., 4 september I961, Pas., I962, I, I5.

I6I K. Mees, Preadvies betreffende delegatie van wetgevende bevoegdheid, VVSRBN (ed.), Zwolle, W.E.J. Tjeenk Willink, I963, I4.

I62 Zie voetnoot 160 .

I63 Cass. (tweede kamer) 8 oktober 1985 , A.R. 9653; Cass. 26 november I956, AC I957, 204; zie nader J. Velaers, De beperkingen van de vrijheid van meningsuiting, II, 748-749. 
73. Na de Tweede Wereldoorlog deed geen enkele Belgische regering nog een beroep op buitengewone machten. Hieruit kan men echter niet afleiden dat die techniek niet meer kan worden herhaald wegens onbruik. ${ }^{164}$ Wat immers indien ons land opnieuw geconfronteerd zou worden met een (dreigende) oorlog en de regering gebruik zou maken van buitengewone machten? Omwille van de onschendbaarheid van de wet kon de rechter destijds de buitengewone machtenwet niet toetsen aan de Grondwet.

Indien de Koning ongrondwettige besluiten heeft genomen die evenwel vallen binnen de perken van de (bij hypothese) ongrondwettige machtigingswet, kon de rechter de toepassing ervan niet weigeren omdat hij anders het gezag van de wet zou schenden. ${ }^{165}$ De onschendbaarheid van een ongrondwettige buitengewone machtigingswet strekte zich dus uit tot de eruit voortvloeiende ongrondwettige besluiten, op voorwaarde dat deze binnen de perken van de toegekende machten bleven. ${ }^{166}$

Vanuit het oogpunt van de rechtsbescherming is de context echter ingrijpend veranderd door de oprichting van het Grondwettelijk Hof. Indien we als premisse mogen aannemen dat de constitutionele rechter de meerderheidsopvatting volgt en de grondslag van de buitengewone machten vindt in artikel I05 van de Grondwet, rijst de vraag wat dan het lot zal zijn van die delegaties van bevoegdheid die betrekking hebben op voorbehouden bevoegdheden. Dergelijke delegaties zullen veel voorkomend en onvermijdelijk zijn, omdat de regering gedwongen door de oorlogsomstandigheden een aantal ingrijpende maatregelen moet nemen inzake de begroting, het legercontingent, opeisingen, beperkingen van rechten en vrijheden enz. Het Grondwettelijk Hof zal wellicht - zoals het dat doet voor bijzondere machtenwetten (zie nr. 92) - ook in dit geval de spoedige bekrachtiging vereisen van buitengewone machtenbesluiten die materies regelen die de Grondwet aan de wetgever heeft voorbehouden. De geschiedenis toont echter aan dat het niet evident is om in oorlogstijden de wetgevende macht te doen vergaderen.

\section{g. Een mislukte poging tot actualisering van de buitengewone machten}

74. De regering-Van Houtte heeft als enige de noodzaak gevoeld om een wetsontwerp uit te werken dat strekte tot actualisering van de bestaande wetgeving op de buitengewone machten. Omwille van de Koude Oorlog en de spanningen tussen Oost en West werd het noodzakelijk geacht om te anticiperen op een nieuw (internationaal) conflict. De regering argumenteerde dat de goedkeuring van het wetsontwerp een overhaaste stemming in een crisissituatie zou kunnen vermijden

I64 Vgl. M. Uyttendaele, Trente leçons de droit constitutionnel, Limal, Anthemis, 20I4, 520: "Des pouvoirs extraordinaires ont été consentis pour la première fois en 1939 et leur dernière mise en oeuvre remonte à 1949. Il est permis, dès lors, de se demander si ce mode d'élaboration des normes n'est pas tombéen désuétude."

I65 A. Mast en J. Dujardin, Overzicht van het Belgisch Grondwettelijk Recht, Gent, Story-Scientia, I983, 23 I.

I66 Zie ook, zij het met betrekking tot bijzondere machtenwetten, A. Alen en K. MuYlLe, Handboek van het Belgisch Staatsrecht, Mechelen, Kluwer, 2011, 732-733. 
en ervoor zou zorgen dat de uitvoerende macht op elk tijdstip bij machte zou zijn om aan een nieuw gewapend conflict het hoofd te kunnen bieden. ${ }^{167}$

75. Het wetsontwerp strekte ertoe de Koning in oorlogstijd en wanneer de nood hem daartoe dwingt, te machtigen om bij in Ministerraad overlegde besluiten alle wetskrachtige "voorzieningen" te treffen voor het waarborgen van de veiligheid van de Staat, de continue werking van de openbare diensten, de vrijwaring van de economische, sociale en financiële belangen van het land en een goed beheer van de openbare financiën. De besluiten kunnen betrekking hebben op een groot aantal materies, waaronder 's lands veiligheid, burgerlijke en militaire opeisingen, sekwestratie, openbare orde en openbare rust, fiscaliteit en zelfs huur- en pachtovereenkomsten. Het ontwerp van wet verleende de Koning tevens de bevoegdheid om de begrotingswetten te wijzigen en om buitengewone middelen in de Schatkist te voorzien (artikel 2).

In geval van een gewapende aanval tegen 's lands grondgebied verleende het wetsontwerp de Koning de macht om de toegewezen bevoegdheid onmiddellijk uit te oefenen. In dat geval worden de Kamers volgens het ontwerp onmiddellijk bijeengeroepen. Indien de Kamers reeds werden ontbonden en de kiescolleges nog niet werden bijeengeroepen, leidt het besluit van de Koning om gebruik te maken van de buitengewone machten, tot de intrekking van het ontbindingsbesluit. Zijn door de kiescolleges reeds nieuwe Kamers gekozen, dan vergaderen zij onmiddellijk, onverschillig op welke datum zij bij het ontbindingsbesluit werden bijeengeroepen (artikel 3 van het wetsontwerp).

Het wetsontwerp werd in het Parlement niet verder behandeld. Het advies van de afdeling Wetgeving van de Raad van State werd reeds gedeeltelijk besproken (supra nrs. 20-22). In het advies wordt benadrukt dat de wetgever, net zoals in het verleden, moet optreden om de noodtoestand vast te stellen. ${ }^{168}$ Volgens de ontworpen regeling bleef het in beginsel een bevoegdheid van de wetgever om de omvang van de noodtoestand te beoordelen. Het was eenvoudigweg de bedoeling dat een reeds vooraf besproken en bij wet vastgelegde bevoegdheidsoverdracht uitwerking kreeg zodra de wetgever de Koning buitengewone machten zou toekennen. Alleen in geval van een gewapende aanval tegen 's lands grondgebied zouden de buitengewone machten uitwerking kunnen krijgen door een beslissing van de uitvoerende macht zelf. Het koninklijk besluit leidde dan omwille van de noodzaak van parlementaire controle van rechtswege tot de onmiddellijke bijeenroeping van het Parlement. Deze afwijking van het algemeen beginsel dat de wetgever moet optreden voor het uitroepen van een noodtoestand, vond de Raad van State verantwoord vanuit grondwettelijk oogpunt. Er werd geargumenteerd dat reeds vanaf de eerste jaren van de onafhankelijkheid de wetgever erin heeft toegestemd dat van een wettelijke

I67 Parl. St. Kamer, I952-53, nr. I72, p. I.

I68 RvS, afdeling Wetgeving, bij het wetsontwerp betreffende de toekenning aan de Koning van buitengewone machten in oorlogstijd, Parl. St., Kamer, I952-53, nr. I72, p. II. 
regeling wordt afgeweken mits daarover onverwijld overleg wordt gepleegd met het Parlement. ${ }^{169}$

\subsection{Bijzondere machtenwetten}

\section{a. Definitie}

76. Bijzondere machtenwetten verlenen op een groot aantal (meestal sociaaleconomische) domeinen een ruime verordeningsbevoegdheid aan de Koning, zodat gedurende een zekere termijn in die domeinen alle nodige maatregelen worden genomen door de federale uitvoerende macht, die hierbij over een ruime discretionaire bevoegdheid beschikt, gelet op de algemene en vage formulering van de te bereiken doelstellingen. ${ }^{170}$

De besluiten genomen op grond van bijzondere machten kunnen de bestaande wetten opheffen, wijzigen of vervangen. Na het verstrijken van de duur waarvoor de machten werden toegekend, kunnen de besluiten slechts worden gewijzigd of opgeheven door of krachtens een wet in de formele zin. De Koning behoudt evenwel het recht om bepalingen die onder zijn bevoegdheid vallen, te wijzigen of op te heffen. ${ }^{17 \mathrm{I}}$

\section{b. Ontstaansgeschiedenis en verdere evolutie}

77. De wet van I6 juli 1926 betreffende zekere te nemen maatregelen met het oog op de verbetering van de financiële toestand wordt vrij algemeen beschouwd als de eerste wet waarbij de wetgever bijzondere machten toekent aan de Koning. ${ }^{172}$ Op grond van deze wet kon de Koning door middel van in Ministerraad overlegde besluiten onder meer alle bepalingen wijzigen betreffende de geldhoeveelheid, leningen aangaan en op de belastingen en de taksen verhogingscoëfficiënten toepassen. De machtiging werd verleend voor een termijn van zes maanden. Met tal van maatregelen, die werden opgenomen in 46 koninklijke besluiten, kon de regering-Jaspar I de Belgische frank redden en een doeltreffend antwoord bieden op de economische en financiële crisis. ${ }^{173}$ Sinds die wet is het gebruikelijk dat bijzondere machtenbesluiten genomen worden na overleg in de Ministerraad. Die substantiële vormvereiste heeft ook een politieke component, omdat het overleg in een collegiaal orgaan vermijdt dat individuele ministers het (herstel)beleid doorkruisen met een eigengereid optreden en de cohesie binnen de regering aantasten.

I69 RvS, afdeling Wetgeving, bij het wetsontwerp betreffende de toekenning aan de Koning van buitengewone machten in oorlogstijd, Parl. St., Kamer, I952-53, nr. I72, p. I2.

I70 De definitie werd ontleend aan A. Alen en K. Muylle, Handboek van het Belgisch Staatsrecht, Mechelen, Kluwer, 20II, 730.

I7I RvS, afdeling Wetgeving, I3 januari I982, Parl. St., Kamer, I98I-82, nr. 28/3I, p. 5.

I72 BS I7 juli i926.

I73 H. Tingsten, Les pleins pouvoirs, Stock, Parijs, I934, I46 en J. Velaers, "Crisissen zijn uitdagingen. Constitutionele crisissen dagen de Grondwet uit”, in A. Alen, V. Joosten, R. Leysen en W. Verriddt (eds.), Liberae Cogitationes. Liber Amicorum Marc Bossuyt, Antwerpen, Intersentia, 2013, 857. Velaers benadrukt de uitzichtloosheid van de financiële crisis van 1926 en spreekt over het bedwingen van een constitutionele crisis door het inslaan van nieuwe wegen met constitutionele creativiteit. 
78. De wet van I6 juli I926 was de voorbode van een hele reeks van bijzondere machtenwetten. Indien het land geplaagd werd door monetaire, budgettaire, economische of sociale crisissen kon de parlementaire meerderheid herhaaldelijk overtuigd worden tot het verlenen van bijzondere machten. Vooral van I933 tot net voor de Tweede Wereldoorlog en tijdens de economische crisis van de jaren tachtig van de vorige eeuw maakte de regering gebruik van bijzondere machten. ${ }^{174}$ Sinds I935 is het gebruikelijk om koninklijke besluiten op grond van bijzondere machten te nummeren. ${ }^{175}$ Daarmee wordt duidelijk gemaakt dat deze besluiten voortaan slechts door of krachtens een wet kunnen worden gewijzigd. ${ }^{176}$

79. Door de goedkeuring van een bijzondere machtenwet geeft de wetgever te kennen dat hij de vereiste wetsbepalingen niet zelf kan vaststellen omwille van de spoedeisendheid en omwille van de openbaarheid die kenmerkend is voor de totstandkoming van de wet. ${ }^{177}$ Het procedé van de bijzondere machten groeide in de praktijk uit tot het juridisch instrument bij uitstek om bepaalde "noodtoestanden" of beter "crisisomstandigheden" te bekampen.

Een sociaal-economisch herstelbeleid kan evenwel moeilijk worden gerealiseerd zonder wijzigingen aan te brengen in het belastingstelsel. De bijzondere machtenwet zal vaak uitdrukkelijk aan de Koning de macht geven om de belastingwetgeving te wijzigen, hoewel het invoeren van belastingen of het wijzigen van tarieven of andere essentiële elementen een bevoegdheid is die de Grondwet aan de wetgever voorbehoudt. Om aan die schending van de Grondwet zo veel als mogelijk te verhelpen, is het gebruikelijk om in de bijzondere machtenwet te bepalen dat de koninklijke besluiten die fiscaalrechtelijke bepalingen wijzigen, bij wet moeten worden bekrachtigd. ${ }^{178}$

I74 Door de wet van I7 mei I933 werden aan de Koning bijzondere machten verleend voor drie maanden. De bijzondere machten werden door de wet van 3I juli 1934 toegekend voor de duur van zes maanden. Ze werden achtereenvolgens verlengd op 7 december 1934 voor een maand en op I5 maart I935 voor drie maanden. Op 30 maart I935 kwam er een verlenging tot I april I936.

I75 G. PiQuet, "L'exercice des pouvoirs spéciaux en ig67", RJDA ig67, 272.

I76 O.m. tijdens de regering-Dehaene II werden echter ook bijzondere machtenbesluiten genomen zonder nummering. Het gebeurt daarenboven soms dat gewone uitvoeringsbesluiten ook worden genummerd (bvb. de koninklijke besluiten ter uitvoering van de Privacywet). Zie A. Alen en K. MuYLle, Handboek van het Belgisch Staatsrecht, Mechelen, Kluwer, 734, noot I8.

I77 A. AlEn, "De bijzondere machten: een nieuwe besluitenregering in België?", TBP I986, 209; A. D’Alcantara, "Parlement en Regering", Brussel, Studiecentrum Politieke Instellingen vzw, I990, 9. Deze voormalige minister drukt zijn kritiek in niet mis te verstane bewoordingen uit: "Door bijzondere machten toe te passen tracht men in ons land het gebrek aan stabiliteit te verhelpen van onze regeringen die, samengesteld op basis van het coalitiesysteem, meer dan een homogene regering blootstaan aan interne wrijvingen, verlammende tactische maneuvers en een haast bestendig latent wantrouwen."

I78 Zie reeds in die zin artikel 2 van de wet van 3i juli 1934 waarbij aan de Koning bepaalde machten worden toegekend met het oog op het economisch en financieel herstel en de vermindering van de openbare lasten (BS I augustus I934): "De bij deze wet aan de Koning verleende machten eindigen bij het verstrijken van een termijn van zes maanden. Op dat ogenblik wordt aan de Kamers verslag uitgebracht over de door de regering getroffen maatregelen.

De regering zal, terzelfder tijd, bij het parlement een wetsontwerp aanhangig maken, tot bekrachtiging van de koninklijke besluiten, genomen in uitvoering van littera a, eerste alinea, van I van het eerste artikel van deze wet."

De bekrachtiging van bijzondere machtenbesluiten die de fiscale wetgeving wijzigen, werd echter niet opgelegd door de wet van 3I maart 1967 tot toekenning van bepaalde machten aan de Koning ten einde de economische heropleving, de bespoediging van de regionale reconversie en de stabilisatie van het begrotingsevenwicht te verzekeren (BS 4 april I967). 
8o. Het valt buiten het bestek van deze bijdrage om een overzicht te geven van de talrijke bijzondere machtenwetten. In een bijdrage van I986 heeft AlEN 26 bijzondere machtenwetten opgelijst voor de voorbije zestig jaar. ${ }^{179}$ In totaal werden er in de periode van juli 1926 tot eind 1986 voor een periode van meer dan negen jaar bijzondere machten toegekend. ${ }^{180}$ Voor de periode na 1986 ontbreekt een dergelijk overzicht. Velaers heeft de adviespraktijk van de afdeling Wetgeving van de Raad van State over de bijzondere machtenwetten in kaart gebracht tot 1999. De theorie van de bijzondere machten is in de adviezen bestendig ontwikkeld en scherper gesteld. ${ }^{18 \mathrm{r}}$

De wet van I6 oktober 2009 die machtigingen verleent aan de Koning in geval van een griepepidemie of pandemie is tot op heden de laatste wet waarmee bijzondere machten werden toegekend aan de uitvoerende macht. Deze bijzondere machtenwet is wat atypisch omdat de doelstelling ervan verband houdt met het beschermen van de bevolking tegen besmettelijke ziekten. De ontwikkeling van een wettelijk kader werd door de wetgever zo urgent geacht dat het onmogelijk zou zijn om te wachten op de goedkeuring door het Parlement van de nodige wetten. ${ }^{182}$ In de machtigingswet is uitdrukkelijk bepaald dat de Koning zelfs wetskrachtige besluiten mag nemen in aangelegenheden die de Grondwet uitdrukkelijk aan de wet voorbehoudt. ${ }^{183}$ Net als bij andere bijzondere machtenwetten heeft de wetgever als het ware de eindbeslissing aan zich willen houden door het voorschrift dat de koninklijke besluiten hem ter bekrachtiging moeten worden voorgelegd. Bij gebrek aan bekrachtiging binnen een termijn van een jaar vanaf hun bekendmaking worden de besluiten geacht nooit uitwerking te hebben gehad. ${ }^{184}$

8I. Sinds de wet van 4 augustus 1996 moeten de ontwerpen van koninklijk besluit die van kracht zijnde wettelijke bepalingen kunnen opheffen of wijzigen, zelfs ingeval van hoogdringendheid, voor advies worden voorgelegd aan de afdeling Wetgeving van de Raad van State. ${ }^{185}$ Er kan bijgevolg niet voorbijgegaan worden aan de adviesverplichting. ${ }^{\mathrm{r} 6} \mathrm{Het}$ advies wordt samen met het verslag aan de Koning en het koninklijk besluit waarop het betrekking heeft, bekendgemaakt in het Belgisch Staatsblad. Niet alleen het publiek, maar ook de Voorzitters van de Kamer van volksvertegenwoordigers en de Senaat worden op een bijzondere manier verwittigd. Reeds voor de bekendmaking in het Belgisch Staatsblad wordt aan de Voorzitters van de wetgevende vergaderingen mededeling gedaan van de besluiten, het advies, het verslag aan de Koning en de tekst van de ontwerpen van besluiten die zijn voorgelegd aan de afdeling Wetgeving.

I79 A. ALEN, "De bijzondere machten: een nieuwe besluitenregering in België?", TBP I986, 2I4-2I5.

I80 Ibid., 207.

I8I J. Velaers, De Grondwet en de Raad van State, Afdeling wetgeving, Antwerpen, Maklu, I999, 348.

I82 M.v.T, Parl. St. Kamer, 2008-2009, nr. 2156/00I, 4.

I83 Artikel 3, derde lid, van de wet van I6 oktober 2009.

I84 Artikel 5, § 2, van de wet van I6 oktober 2009.

I85 Artikel 3bis, S§ I en 2 RvS-wet.

I86 Artikel 3bis, § 2 RvS-wet. 
82. Reeds tijdens de parlementaire voorbereiding van de wet van 16 juli 1926 rees de vraag of de toekenning van bijzondere machten wel verenigbaar was met de Grondwet. Ten tijde van die wet werd vrij algemeen aangenomen dat de Belgische Grondwet de verhouding tussen de wetgevende en de uitvoerende macht op een duidelijke en eenvoudige wijze had omschreven. ${ }^{187}$ De federale wetgevende macht wordt gezamenlijk uitgeoefend door de Koning, de Kamer van volksvertegenwoordigers en de Senaat (artikel 26 van de Grondwet van I83I, thans artikel 36 van de gecoördineerde Grondwet). De wetgever beschikt over de residuaire bevoegdheden, terwijl de Koning geen andere macht heeft dan die welke de Grondwet en de bijzondere wetten, krachtens de Grondwet zelf uitgevaardigd, hem uitdrukkelijk toekennen (artikel 78 van de Grondwet van I83I, thans artikel I05 van de gecoördineerde Grondwet). Met die grondwetsbepaling wilde het Nationaal Congres de macht van de Koning inperken door te benadrukken dat hij enkel toegewezen bevoegdheden heeft en slechts ter uitvoering van de Grondwet of een wet kan handelen. De bevoegdheidsverdeling in de Belgische Grondwet kwam tot stand omdat het Nationaal Congres komaf wilde maken met de "besluitenregering" van Willem I. Tijdens zijn bewind had Willem I immers op eigen initiatief "zelfstandige maatregelen van algemeen bestuur" genomen. Hij kon zich gedragen als een usurpator van de wetgevende macht omdat de Grondwet van het Verenigd Koninkrijk der Nederlanden van I8I5 de bevoegdheid van de wetgevende vergadering onvoldoende duidelijk had afgebakend. ${ }^{88}$ Die onduidelijke omschrijving wilde de Belgische grondwetgever voor eens en voor altijd wegwerken door het inperken van de bevoegdheid van de Koning.

83. De grenzen van de reglementaire bevoegdheid van de Koning worden vastgelegd door artikel 67 (thans artikel Io8) van de Grondwet: "De Koning maakt de verordeningen en de neemt de besluiten die voor de uitvoering van de wetten nodig zijn, zonder ooit de wetten zelf te mogen schorsen of vrijstelling van hun uitvoering te mogen verlenen." Het is op het eerste gezicht dus onmiskenbaar zo dat de uitvoerende macht een wet in de formele zin niet kan wijzigen of opheffen door het uitvaardigen van een koninklijk besluit. Ook een delegatie van bevoegdheid uitgaande van de wetgevende macht kan hieraan niet verhelpen. De Belgische Grondwet verzet zich immers tegen een delegatie van de wetgevende macht aan de Koning. Dit verbod wordt afgeleid uit artikel 25 (thans artikel 33) van de Grondwet, dat bepaalt dat de machten moeten worden uitgeoefend op de wijze die door de Grondwet wordt bepaald. Vrij algemeen wordt aangenomen dat een delegatie van de wetgevende macht, die net zoals de andere machten niet kan worden vervreemd of overgedragen, in beginsel in strijd is met de Grondwet. ${ }^{189}$

I87 R. Stragier, "Theorie en praktijk der volmachten", RW i936, 674.

I88 Zie nader A. ALEN, Rechter en bestuur in het Belgisch publiekrecht. De grondslagen van de rechterlijke wettigheidscontrole, Antwerpen, Kluwer, I984, nr. 367 en "Bijzondere machten: een nieuwe 'besluitenregering' in België", TBP I986, I99-200.

I89 Cass. 6 februari i89I, Pas. I89I, I, 54; Cass., io juli 1953, Pas., I953, I, 9I4; A. Mast, J. Dujardin, M. Van Damme en J. Vande LanotTe, Overzicht van het Belgisch AdministratiefRecht, Mechelen, Kluwer, 2OI2, 2I-22. 
84. Het stelsel van de Grondwet lijkt op het eerste gezicht dus onverenigbaar met de techniek van de bijzondere machten. Het succesvol gebruik van de bijzondere machten bij het bestrijden van de crisis in 1926 had tot gevolg dat de rechtsleer met onverdroten ijver op zoek ging naar een juridische verantwoording voor de bijzondere machten.

\section{- de theorie van het noodrecht}

85. Een eerste piste die werd bewandeld, is de theorie van het noodrecht. Door sommige auteurs werd geargumenteerd dat de psychologische of morele onmogelijkheid voor de Kamers om met de nodige spoed in anti-crisiswetgeving te voorzien, moet gelijkgesteld worden met de hypothese van de materiële onmogelijkheid. ${ }^{190}$ De gevolgen van de materiële onmogelijkheid die erin bestonden dat de Koning tijdens de Eerste Wereldoorlog als enige tak van de wetgevende macht wetgeving kon uitvaardigen, zouden van overeenkomstige toepassing zijn zodra het Parlement in de bijzondere machtenwet de noodtoestand heeft erkend en impliciet de eigen machteloosheid heeft toegegeven. Naar analogie met de besluitwetten van de oorlogsregeringen werd zelfs geargumenteerd dat de Koning in geval van een noodtoestand niet zal optreden als hoofd van de uitvoerende macht maar als enig overgebleven werkzame tak van de wetgevende macht.

86. Mast en Dujardin hebben terecht uiteengezet dat deze theorie geen steun kan vinden in de Belgische Grondwet en de poort wagenwijd openzet voor misbruiken. De psychologische of morele onmogelijkheid is, in tegenstelling tot een materiële onmogelijkheid, geen objectief gegeven en berust op een subjectieve waardering van een crisissituatie, waarover de meningen erg kunnen verschillen. Een noodtoestand moet net zoals het begrip "overmacht" voldoende objectiveerbaar zijn. De loutere overtuiging van een van de drie staatsmachten dat ze machteloos is en niet geschikt is om op te treden, houdt een abdicatie van bevoegdheid in die de Grondwet niet toelaat.

Zodra men aanvaardt dat het Parlement omwille van een morele onmogelijkheid afstand mag doen van zijn bevoegdheden, bestaat het risico dat dit bij een machtsgreep tegen de Kamers wordt gehanteerd als vals voorwendsel. Een usurpator matigt zich dan de macht aan door abusievelijk voor te houden dat de wetgevende macht niet langer in staat is om zijn taak te vervullen. De meeste auteurs wijzen er terecht op dat dit gevaarlijk denkspoor in strijd is met artikel I87 van de Grondwet, omdat het erkennen van het noodrecht een schorsing inhoudt van de Grondwet. ${ }^{\text {III }}$

I9o Zie P.M. Orban, "De grondslag van de 'volmachtgeving' in België”, Rechtskundig Tijdschrift I938, I27: "De enige uitleg die dienend is, bestaat in het inroepen van een noodtoestand waarin de Staat zich bevinden kan en die hem tot zelfuerdediging noopt." In de zelfde zin: La réforme de l'Etat, Centre d'Etudes pour la réforme de l'Etat (ed.), Brussel, Ravenstein, I937, 85-87 (het gaat hier om een weergave van de meerderheidsopvatting binnen de tweede commissie).

igi A. Alen en K. Muylle, Handboek van het Belgisch Staatsrecht, Mechelen, Kluwer, 20II, 734, noot I8; A. MASt, "Le problème de la législation déléguée", JT 1946, 625; A. MAST en J. DuJARdin, Overzicht van het Belgisch Grondwettelijk Recht, Gent, Story-Scientia, I983, 234; R. OcKrent, Les crises constitutionnelles du Pouvoir législatif en Belgique. Les pouvoirs des Secrétaires généraux sous l'occupation ennemie, Brussel, I945, 30, nr. I2. Zie tevens de stellingname van H. SPEyer: "En réalité, une déclaration d'impuissance morale telle qu'elle est prévue dans les conclusions de la Commission et qui aboutirait au transfert, 
87. Reeds ten tijde van de wet van i6 juli 1926 werd door Van Dievoet en Vauthier verdedigd dat de grondslag van de bijzondere machten bestond in een uitbreiding van de verordenende bevoegdheid van de Koning. ${ }^{192}$ De techniek van de bijzondere machten zou volgens SPEYer steun vinden in artikel 78 (thans artikel I05) van de Grondwet, dat het voor de wetgever mogelijk maakt om de residuaire bevoegdheid bij "bijzondere wet" (bedoeld is elke opdrachtwet) toe te wijzen aan de Koning. SPEYer argumenteert dat een machtigingswet die steunt op artikel 78 (thans artikel 105) van de Grondwet, aan de Koning het recht kan opdragen om bestaande wetten te wijzigen. Precies door de attributie van bevoegdheid geeft de wetgever te kennen dat de materie die wordt aangewezen in de machtigingswet tijdelijk behoort tot de bevoegdheidssfeer van de uitvoerende macht. Wanneer de wetgever de bevoegdheid van de Koning regelt of zelfs wanneer hij deze uitbreidt buiten de perken waarin ze gewoonlijk besloten ligt, gaat hij niet in tegen de Grondwet, maar voert hij een opdracht uit welke de Grondwet hem toevertrouwt.

Niets belet de wetgever om de Koning te machtigen om in een bepaald domein de wet te wijzigen. Dit houdt geen schending in van artikel 67 (thans artikel ro8) van de Grondwet, op grond waarvan de Koning de wet niet vermag te schorsen of te wijzigen. Die grondwetsbepaling formuleert immers slechts een verbod voor de Koning en verzet zich niet tegen een uitbreiding van de verordenende macht van de Koning in het raam van artikel ro5 van de Grondwet.

De rechtsleer benadrukt dat de bijzondere machtenwetten geen delegatie zijn van de wetgevende macht - hetgeen door de Grondwet verboden wordt - maar dat zij een attributie inhouden van bepaalde aangelegenheden aan de Koning die voorzien is in artikel ro5 van de Grondwet. ${ }^{193}$

88. Er is thans een grote eensgezindheid om de juridische verantwoording voor de bijzondere machtenwetten te ontlenen aan artikel I05 van de Grondwet. ${ }^{194}$ Volgens de rechtspraak van het Hof van Cassatie is de juridische verantwoording

même pour un temps limité, du pouvoir de légiférer entre les mains du Roi seul, contrairement à l'article 25 de notre pacte fondamental, constitue une suspension partielle de la Constitution formellement interdite par l'article 130 de celle-ci" (La réforme de l'Etat, Centre d'Etudes pour la réforme de l'Etat (ed.), Brussel, Ravenstein, I937, 73-I34). In dezelfde zin G. PiQuet, "L'exercice des pouvoirs spéciaux en I967", RJDA i967, 272.

I92 Annales parlementaires, I926, 2177. VAN Dievoet en VAUthier verdedigden de theorie van de "détermination de compétence", die ervan uitgaat dat de wetgever de omvang kan bepalen van de bevoegdheid die wordt toegewezen aan de uitvoerende macht. Die theorie is de voorbode van de attributietheorie. Zie nader J. Mertens, Le fondement juridique des lois de pouvoirs spéciaux, Brussel, Larcier, I945, II5-II9. Voor een overzicht van de verschillende opvattingen, zie Centre d'Etudes pour la réforme de l'Etat (ed.), La réforme de l'Etat, Brussel, Ravenstein, I937, 73-I34.

I93 A. Alen en K. Muylle, Handboek van het Belgisch Staatsrecht, Mechelen, Kluwer, 20II, 734; F. Delpérée, Le droit constitutionnel de la Belgique, Brussel, Bruylant, LGDJ, Parijs, 2000, 77I.

I94 Zie nader A. Alen, "De grondslag van de bijzonderemachtenwetgeving", RW I983-84, 4I8-428; RvS, afdeling Wetgeving, Parl. St. Kamer, I98I-82, nr. I, p. 5. Op het niveau van de gemeenschappen en gewesten kan de decreetgever of ordonnatiegever een beroep doen op artikel 78 BWHI. Op grond van deze bepaling heeft de regering geen andere macht dan die welke de Grondwet en de wetten en decreten krachtens de Grondwet uitgevaardigd, haar uitdrukkelijk toekennen. Artikel 78 BWHI spoort met artikel I05 van de Grondwet. 
voor de bijzondere machtenwetgeving in die bepaling gelegen omdat ze nu eenmaal toestaat dat een "bijzondere wet" (opdrachtwet), krachtens de Grondwet zelf uitgevaardigd, de uitoefening van de verordenende macht buiten de door artikel 67 (thans artikel 108) van de Grondwet gestelde grenzen uitbreidt. ${ }^{195}$ In zijn conclusie bij het arrest van 3 mei 1974 heeft procureur-generaal GANSHOF VAN DER MEERSCH erop gewezen dat niet alleen in de wetgevende praktijk ${ }^{196}$ steun te vinden is voor de opvatting dat de Koning, handelend binnen de grenzen van een door een bijzondere wet verleende machtiging, een wet kan wijzigen of opheffen, maar dat ook de parlementaire voorbereiding van artikel 67 (thans artikel ro8) van de Grondwet hiervan uitdrukkelijk gewag maakt. ${ }^{197}$

\section{d. Grenzen aan het procedé van de bijzondere machten}

89. Ook de afdeling Wetgeving van de Raad van State aanvaardt in haar adviespraktijk dat de uitbreiding van de verordeningsbevoegdheid van de Koning steunt op artikel I05 van de Grondwet. ${ }^{198}$ Een onbeperkte toekenning van bijzondere machten is echter niet verenigbaar met het stelsel van de Grondwet. Een bijzondere machtenwet is daarom slechts verenigbaar met het geheel van de grondwettelijke regels die de verhouding tussen de wetgevende en de uitvoerende macht regelen indien aan drie voorwaarden is voldaan.

Ten eerste moeten er uitzonderlijke omstandigheden aanwezig zijn. Het staat aan de wetgever om uit te maken of de ingeroepen omstandigheden als voldoende uitzonderlijk kunnen worden aangemerkt om de verregaande bevoegdheidstoewijzing te verantwoorden. ${ }^{199}$ Het toekennen van bijzondere machten kan slechts in "crisisomstandigheden". De beoordelingsmacht van de wetgever is echter niet onbegrensd, zodat er ruimte is voor een marginale toetsing. Indien de wetgevende macht de feitelijke omstandigheden kennelijk zou vertekenen of hieromtrent een inschatting zou maken die duidelijk buiten verhouding tot die omstandigheden zou staan, kan het Grondwettelijk Hof dit sanctioneren. ${ }^{200}$ Het Grondwettelijk Hof oordeelde dat de noodzaak voor de regering om snel en efficiënt te kunnen optreden, bij wijze van zeer technische maatregelen, om de in het Verdrag van Maastricht geformuleerde doelstellingen inzake het begrotingstekort te bereiken

I95 Cass. 3 mei 1974, RW I974-75, 78, conclusie Proc.-gen. Ganshof van der Meersch en noot De Meyer; Cass. 25 juni 1974 , RW I974-75, I08, conclusie Adv.-gen. Dumon.

I96 Het loutere bestaan van een wetgevende praktijk volstaat uiteraard niet indien de Grondwet die praktijk verbiedt. Sinds de oprichting van het Grondwettelijk Hof in I984 kan een ongrondwettige wetgevende praktijk ook daadwerkelijk worden gesanctioneerd.

I97 E. Huytrens, Discussions du Congrès national de Belgique (1830-1831), IV, Brussel, I844, 84-86.

I98 Zie o.m. RvS, afdeling Wetgeving, advies nr. 47.062/I/V van I8 augustus 2009, Parl. St. Kamer, 2008-2009, nr. 52-2156/00I, p. I7; RvS, afdeling Wetgeving, advies nr. 50.472/I/2 van 20 december 20II, Parl. St., Kamer, 20II-20I2, nr. 53-I952/I3, p. 5; RvS, afdeling Wetgeving (verenigde kamers), advies van 23 december I98I, Parl. St. Kamer, I98I-82, nr. 28/I, p. 5.

I99 RvS, afdeling Wetgeving, advies nr. 47.062/I/V van I8 augustus 2009, Parl. St. Kamer, 2008-2009, nr. 5I-2I56/00I, p. I7.

200 Zie in die zin RvS, afdeling Wetgeving, Parl. St., Kamer, I982-83, nr. I3, p. 2. De zinsnede uit het advies heeft betrekking op de taak van de afdeling Wetgeving, maar is van overeenkomstige toepassing op de constitutionele rechter; A. Alen en K. Muylle, Handboek van het Belgisch Staatsrecht, Mechelen, Kluwer, 20II, 735; J. Vande Lanotte, G. Goedertier, Y. Haeck, J. Goossens en T. De Pelsmaeker, Belgisch Publiekrecht, I, Brugge, die Keure, 2015, I35, noot 223. 
en te kunnen toetreden tot de Europese Economische en Monetaire Unie, een beroep op bijzondere machten kan verantwoorden. ${ }^{20 r}$

Ten tweede mogen de bijzondere machten slechts voor een beperkte periode aan de Koning worden toegekend. De uitzonderlijke omstandigheden bepalen overigens de grenzen van de periode gedurende welke die machten kunnen worden toegekend. ${ }^{202}$ Een periode van 13 tot 14 maanden - veel korter dus dan de duur van de buitengewone machten (zie nr. 67) - is een absoluut maximum. ${ }^{203}$

Ten derde moeten de toegekende machten nauwkeurig omschreven zijn. Zowel wat betreft de doeleinden en de oogmerken, als wat betreft de aangelegenheden waarin maatregelen kunnen worden genomen, moet de machtigingswet duidelijkheid verschaffen. De noodzaak om bijzondere machten met grote precisie te omschrijven, kan worden afgeleid uit artikel I05 van de Grondwet, dat bepaalt dat de Koning geen andere macht heeft dan die welke de Grondwet en de "bijzondere wetten" (opdrachtwetten), krachtens de Grondwet zelf uitgevaardigd, hem uitdrukkelijk toekennen. Ook een rechterlijke toetsing is gebaat met een machtigingswet die nauwkeurig de omvang van de bijzondere machten vaststelt. ${ }^{204}$ Wegens het uitzonderlijke karakter ervan, dient het toekennen door de wetgever van bijzondere machten aan de Koning strikt te worden geïnterpreteerd. ${ }^{205}$ Indien de machtigingswet vaag is omtrent de bevoegdheid van de Koning, moet de regel van de restrictieve interpretatie ertoe leiden dat de Koning de bevoegdheid mist om een voorbehouden bevoegdheid te regelen. ${ }^{206}$

\section{e. Bijzondere machten en de delegatie van een voorbehouden bevoegdheid}

9o. Indien de Grondwet bepaalt dat een aangelegenheid moet worden geregeld "bij" of "door" de wet is de regeling ervan door de Grondwet voorbehouden aan de wetgever. Dit heeft tot gevolg dat een optreden van de wetgever vereist is en dat de wetgever de regeling ervan niet kan opdragen aan de Koning. Tot het exclusieve takenpakket van de wetgever behoren onder meer de bescherming van de rechten en vrijheden, het onderwijs en het taalgebruik (Titel II van de Grondwet), de inrichting van de rechtscolleges (Titel III, hoofdstukken VI en VII van de Grondwet), het heffen van belastingen (artikelen I70 en 172 van de Grondwet), en de organisatie van het leger en van de politie (artikelen I82 en I84 van de Grondwet).

\footnotetext{
201 GwH nr. I24/2002, Io juli 2002, B.4.20

202 RvS, afdeling Wetgeving, advies nr. 47.062/I/V van I8 augustus 2009, Parl. St. Kamer, 2008-2009, nr. 5I-2I56/00I, p. I7, noot 2.

203 A. Alen en K. Muylle, Handboek van het Belgisch Staatsrecht, Mechelen, Kluwer, 20II, 735, noot 22.

204 RvS, afdeling Wetgeving, Parl. St., Kamer, I98I-82, nr. I, p. 5.

205 Zie o.m. GwH nr. 68/99, I4 juni r999, B.5.4; Cass. I9 januari 1959, A.C. 1959, 397.

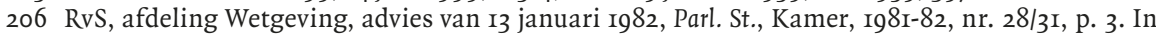
geval van een onduidelijke machtigingswet moet de rechter er immers volgens de leer van het arrest-Waleffe in redelijkheid van uitgaan dat de wetgever niet de bedoeling kan hebben gehad de Grondwet te schenden. Hij moet in die hypothese de voorkeur geven aan een grondwetsconforme interpretatie: Cass., 20 april I950, Pas., I950, I, 560, conclusie Proc.-gen. L. CornIL. De leer van dit arrest is van overeenkomstige toepassing op buitengewone machtenwetten.
} 
91. De meeste auteurs zijn van oordeel dat een uitbreiding van de verordenende bevoegdheid van de Koning in beginsel niet zover kan gaan dat hem een bevoegdheid wordt gegeven in aangelegenheden die, volgens de Grondwet, tot de eigen bevoegdheid van de wetgever behoren, zoals het invoeren van een belasting. ${ }^{207} \mathrm{De}$ attributietheorie steunt op het uitgangspunt dat de wetgever vrij over de residuaire bevoegdheid mag beschikken en laat bijgevolg niet toe dat de Koning besluiten neemt in materies die door de Grondwet worden voorbehouden aan de wetgever.

Indien de bijzondere machtenwet de Koning uitdrukkelijk de bevoegdheid toekent om op te treden in voorbehouden aangelegenheden, wordt die inbreuk op het delegatieverbod enkel in overeenstemming geacht met de geest van de Grondwet indien aan drie bijkomende voorwaarden is voldaan: (i) de machtigingswet moet duidelijk aangeven dat de opdracht ook betrekking kan hebben op voorbehouden bevoegdheden; ${ }^{208}$ (ii) de door de Koning genomen maatregelen moeten door de wetgevende macht worden onderzocht binnen een relatief korte termijn, vastgesteld in de machtigingswet, en er moet worden bepaald dat de genomen besluiten bij ontstentenis van wetgevende bekrachtiging moeten worden geacht nooit uitwerking te hebben gehad; ${ }^{209}$ (iii) de wetgever moet zich in de onmogelijkheid bevinden om zelf alle essentiële elementen van de regeling vast te stellen, omdat de inachtneming van de gebruikelijke procedure hem niet toelaat met de nodige spoed te handelen om een doelstelling van algemeen belang te verwezenlijken.

92. Deze bijkomende voorwaarden, die reeds lang werden geformuleerd in de adviespraktijk van de afdeling Wetgeving van de Raad van State, werden overgenomen in de rechtspraak van het Grondwettelijk Hof. Een arrest van 2 I maart 2000 is in dit verband bijzonder illustratief. Het beroep tot vernietiging werd ingesteld tegen de artikelen 2 en 3 van de wet van 8 december 1998 houdende diverse bepalingen betreffende de financiering van het Instituut voor veterinaire keuring. De wet machtigde de Koning onder meer om uiterlijk binnen het jaar na de bekendmaking ervan bij een in Ministerraad overlegd koninklijk besluit, het bedrag en de wijze van berekening van een fiscale heffing te bepalen ten laste van de exploitanten van slachthuizen.

207 A. AlEn, “Bijzondere machten: een nieuwe 'besluitenregering' in België?”, TBP I986, 204; G. Piquet, "L'exercice des pouvoirs spéciaux en I967", RJDA I967, 272 en 278; R. Henrion, "L'expérience des lois de pouvoirs exceptionnels", JT i968, 469.

208 Die aangelegenheden moeten uitdrukkelijk worden opgesomd, zodat het onderwerp van de machtiging ondubbelzinnig vaststaat.

209 RvS, afdeling Wetgeving, advies nr. 47.062/I/V, Parl. St. Kamer, 2008-2009, nr. 5I-2I56/00I, p. I9; $\mathrm{RvS}$, afdeling Wetgeving, advies nr. 50.472/I/2 van 20 december 20II, Parl. St. Kamer, 20II-20I2, nr. 52-I952/I3, p. 5-6; Zie tevens GwH, nr. I95/2004, I december 2004, B.I6.3; nr. 83/2008, 27 mei 2008 , B.5.2. Het bekrachtigingsbeding dat verplicht wordt opgelegd in een bijzondere machtenwet indien de wetgever de Koning machtigt tot het regelen van een aangelegenheid die door de Grondwet aan de wetgever wordt voorbehouden, strekt ertoe de machtiging zo veel als mogelijk te verzoenen met de Grondwet. De wetgever wil de eindbeslissing aan zich houden met het voorschrift dat de koninklijke besluiten hem ter bekrachtiging moeten voorgelegd worden en neemt genoegen met het minder volmaakt stelsel van de bekrachtiging (J. MASQUELIN, "La fonction réglementaire et les pouvoirs spéciaux”, Rec. jur. dr. adm. et Cons. D’Etat, I969, 20-2I; Verslag Brusselmans, Parl. St. Kamer, I933-34, nr. 27I, p. 7; Verslag Moyersoen, Parl. St. Senaat, I933-34, p. I2). 
Wanneer de wetgever aan de Koning de fiscale bevoegdheid verleent die bij de artikelen 170 en 172 van de Grondwet aan de wet wordt voorbehouden, voert hij, aldus het Hof, onmiskenbaar een verschil in behandeling in tussen twee categorieën van belastingplichtigen, namelijk degenen die de waarborg genieten dat niemand kan worden onderworpen aan een belasting indien daartoe niet is beslist door een democratisch verkozen beraadslagende vergadering en degenen aan wie die grondwettelijke waarborg wordt ontzegd. Dat verschil in behandeling is in beginsel niet te verantwoorden. ${ }^{210}$ Elke delegatie die betrekking heeft op het bepalen van een van de essentiële elementen van de belasting is immers in beginsel ongrondwettig. ${ }^{211}$

De inbreuk op het gelijkheidsbeginsel en op artikel I70 van de Grondwet wordt evenwel door het Hof niet gesanctioneerd omwille van twee redenen. Ten eerste voorziet de machtigingswet erin dat de door de Koning genomen maatregelen binnen een relatief korte termijn door de wetgevende macht zullen worden onderzocht met het oog op hun bekrachtiging en dat de besluiten met terugwerkende kracht worden opgeheven indien ze niet tijdig door de wetgever zijn bekrachtigd.212 Ten tweede is er sprake van een aangevoerde noodzakelijkheid die het beroep op de bijzondere machten kan verantwoorden.

De technische uitwerking van de in de wet vervatte principes met de noodzaak om voorafgaand te overleggen met de sectoren en de noodzaak om de besluiten die de heffing invoeren, snel bij te sturen wanneer uit de toepassing ervan zou blijken dat dit nodig is, kan, aldus het arrest van 2I maart 2000, het beroep op bijzondere machten verantwoorden. ${ }^{213}$ Velaers is terecht kritisch ten aanzien van de grondwettigheid van deze vorm van "proefregeling bij koninklijk besluit", omdat het aanvaarden ervan leidt tot een uitholling van de voorbehouden aangelegenheden. ${ }^{214}$

93. Uit rechtspraak van een latere datum blijkt dat er uitzonderlijke omstandigheden aanwezig moeten zijn die de machtiging kunnen verantwoorden. ${ }^{215}$ In een arrest van I december 2004 oordeelde het Hof dat het nagestreefde doel van budgettaire stabiliteit weliswaar een zekere spoed vereist om de tarieven aan te passen, maar dat de bestaande verschillen tussen de procedures voor de aanneming van de wettelijke en de reglementaire normen op zich niet volstaan om te verantwoorden dat een aangelegenheid die de Grondwet aan de wet voorbehoudt, aan de uitvoerende macht wordt opgedragen. De wetgever moet aantonen dat hij zich in

2I0 GwH nr. 32/2000, 2I maart 2000, B.7.2. Zie tevens GwH nr. I95/2004, I december 2004, B.I6.3.

2II GwH nr. 195/2004, I december 2004, B.I6.3.

2I2 GwH nr. 68/99, I7 juni I999, B.5.5: de uitdrukkelijke machtiging in de bijzondere machtenwet en de navolgende bekrachtiging door de wetgever zijn cumulatieve voorwaarden opdat de Koning de door de Grondwet aan de wetgever voorbehouden bevoegdheid kan uitoefenen; GwH nr. 32/2000, 2I maart 2000, B.7.7.

2 I3 GwH nr. 32/2000, 2I maart 2000, B.7.8; GwH nr. 53/2003, 30 april 2003, B.3.5.

2I4 J. Velaers, "Het recht op de wetgever. Beschouwingen over de voorbehouden en residuaire bevoegdheden", in En Hommage à Francis Delpérée, Itinéraires d'un constitutionnaliste, Brussel, Bruylant, $2007, \mathrm{I} 637$.

215 A. Alen en K. Muylle, Handboek van het Belgisch Staatsrecht, Mechelen, Kluwer, 20II, 737; K. Muylle en J. Theunis, "La Cour constitutionnelle comme juge de la séparation des pouvoirs: le cas des délégations et des validations", in Liber Amicorum Michel Melchior, Brussel, Anthemis, 2010, I23I24 en de verwijzingen aldaar. 
de onmogelijkheid bevindt om zelf alle essentiële elementen van de voorbehouden aangelegenheid te regelen, omdat de inachtneming van de parlementaire procedure hem niet in staat zou stellen om met de vereiste spoed te handelen om een doelstelling van algemeen belang te verwezenlijken. ${ }^{216}$

94. In een andere zaak probeerde de belastingplichtige het Grondwettelijk Hof te bewegen tot een koerswijziging door de schending aan te voeren van het gelijkheidsbeginsel in combinatie met artikel ro5 van de Grondwet. Dit leverde echter niet het door hem gewenste resultaat op. Wanneer een specifieke grondwetsbepaling de waarborg biedt dat over een der essentiële elementen van een aangelegenheid door een democratisch verkozen beraadslagende vergadering dient te worden beslist, wordt de waarborg van artikel I05 van de Grondwet daardoor opgeslorpt. Uit de vaststelling dat de wetgever geen afbreuk heeft gedaan aan de artikelen Io,II, I70 en I72 van de Grondwet, volgt volgens het Hof dat hij evenmin op discriminerende wijze afbreuk heeft gedaan aan artikel I05 van de Grondwet. ${ }^{217}$

\section{f. Versterkte en verzwakte legaliteitsbeginselen}

95. De voormelde afzwakking van het delegatieverbod geldt echter niet inzake onderwijs en in strafzaken, aangezien in die twee materies een versterkt wettigheidsbeginsel geldt. ${ }^{218}$ Met de goedkeuring van artikel 24, § 5, van de Grondwet heeft de grondwetgever het wettigheidsbeginsel inzake onderwijs willen versterken. ${ }^{219} \mathrm{De}$ essentiële aspecten van de inrichting, erkenning en subsidiëring zijn voorbehouden aan de bevoegde wetgever. ${ }^{220}$ Een a posteriori bekrachtiging kan niet verhelpen aan een verboden delegatie aan de uitvoerende macht. ${ }^{221}$

Eenzelfde bescherming biedt het versterkt strafrechtelijk wettigheidsbeginsel. De strafbaarstelling van gedragingen, alsook het bepalen van de vorm van de vervolgingen en van de toepasselijke straffen, vereist een tussenkomst van een democratisch verkozen beraadslagende vergadering (artikel I2, tweede lid, en artikel I4 van de Grondwet). De essentiële elementen ervan kunnen niet worden gedelegeerd aan een uitvoerend orgaan. Indien dit toch het geval is, kan geen $a$ posteriori bekrachtiging aan de ongrondwettigheid van een essentiële bepaling van materieel of formeel strafrecht verhelpen. ${ }^{222}$

Omgekeerd heeft het Grondwettelijk Hof een afzwakking van het wettigheidsbeginsel aanvaard voor de sociaal-economische grondrechten die zijn neergelegd in artikel 23 van de Grondwet. De wetgever vermag in die materies ruime delegaties aan de Koning te verlenen, voor zover zij betrekking hebben op "het aannemen

216 GwH nr. I00/2003, I7 juli 2003, B.II.2; GwH nr. I95/2004, I december 2004, B.I6.3-B.I6.4.

$217 \mathrm{GwH}$ nr. 88/2004, I9 mei 2004, B.8.4.

2I8 Zie nader: K. Muylle en J. Theunis, "La Cour constitutionnelle comme juge de la séparation des pouvoirs: le cas des délégations et des validations”, in Liber Amicorum Michel Melchior, Brussel, Anthemis, 2010, I24-I26.

2I9 GwH nr. 45/94, I juni i994, B.6.

$220 \mathrm{GwH}$ nr. I9/99, I7 februari I999; GwH, nr. 40/20II, I5 maart 20II; zie nader B. SteEn, "Experimenten in het onderwijs: een zaak van de regering of het parlement", TORB 2004-2005, 279-292.

22 A. Alen en K. Muylle, Handboek van het Belgisch Staatsrecht, Mechelen, Kluwer, 20II, 44I-443.

222 A. Alen en K. Muylle, Handboek van het Belgisch Staatsrecht, Mechelen, Kluwer, $2011,736$. 
van maatregelen waarvan het onderwerp door de bevoegde wetgever is aangegeven". ${ }^{223}$ Die rechtspraak is te verklaren doordat grote delen van het Belgische sociaal recht administratief besluitenrecht zijn, een historisch gegeven dat de grondwetgever, die op 3I januari 1994 artikel 23 aan Titel II van de Grondwet heeft toegevoegd, bekend was. ${ }^{224}$

\section{g. Rechterlijke toetsing van bijzondere machtenbesluiten}

96. Een koninklijk besluit genomen krachtens een bijzondere machtenwet is een handeling van de uitvoerende macht, die door de hoven en rechtbanken op grond van artikel 159 van de Grondwet aan de wet kan worden getoetst en waartegen een annulatieberoep bij de afdeling Bestuursrechtspraak van de Raad van State openstaat. Een wet die de uitvoerende macht machtigt om, in welbepaalde omstandigheden, bepalingen van wetgevende aard te wijzigen, kent immers niet de hoedanigheid van wetgevende handelingen in formele zin toe aan de handelingen van de uitvoerende macht die in het kader van een dergelijke machtiging zijn genomen. ${ }^{225}$ De toetsing van bijzondere machtenbesluiten aan de Grondwet wordt wel bemoeilijkt door de vage doelstellingen in de machtigingswetten: indien het besluit in strijd is met de Grondwet, terwijl het op zich niet in strijd is met de machtigingswet, impliceert dit doorgaans dat ook de machtigingswet zelf ongrondwettig is. Die laatste toetsing valt evenwel buiten de rechtsmacht van de gewone rechter en de Raad van State, die dus vaak verplicht zullen zijn een prejudiciële vraag te stellen aan het Grondwettelijk Hof. ${ }^{226}$

De bekrachtiging door de wetgever van een bijzondere machtenbesluit heeft tot gevolg dat het besluit aan het rechterlijk wettigheidstoezicht wordt onttrokken en dat het niet langer een voor een annulatieberoep bij de Raad van State vatbare handeling is. Door de bekrachtiging wordt een bijzondere machtenbesluit met terugwerkende kracht beschouwd als gelijkgesteld met een wet. Het Grondwettelijk Hof is bijgevolg bevoegd om kennis te nemen van het beroep tot vernietiging van een bekrachtigd bijzondere machtenbesluit. ${ }^{27}$

Door de bekrachtiging van een bijzondere machtenbesluit eigent de wetgever zich de daarin geregelde aangelegenheden toe. ${ }^{228}$ De termijn voor een beroep tot vernietiging bij het Grondwettelijk Hof gaat bijgevolg in op de datum van de bekendmaking van de bekrachtigingswet, zowel wat deze laatste als wat het bekrachtigde bijzondere machtenbesluit betreft. Vóór deze datum kan tegen het bijzondere machtenbesluit als handeling van de uitvoerende macht immers geen beroep tot

223 GwH nr. I8/98, I8 februari I998; GwH nrs. I03/99 en I04/99, 6 oktober I999; GwH nr. 93/2002, 5 juni 2002; GwH nr. I47/2005, 28 september 2005; GwH nr. I03/2006, 2I juni 2006; GwH nr. 66/2007, 26 april 2007; GwH nr. I82/2008, I8 december 2008; GwH nr. I35/2010, 9 december 20I0; GwH nr. I5I/2010, 22 december 2010.

224 G. MAEs, De afdwingbaarheid van sociale grondrechten, Antwerpen, Intersentia, 2003, 4I5-4I9.

$225 \mathrm{GwH}$ nr. I63/2005, 9 november 2005.

226 A. Alen en K. MuYlle, Handboek van het Belgisch Staatsrecht, Mechelen, Kluwer, 20II, 733-734.

227 GwH nr. 7I/88, 2I december I988, I.B.I.

$228 \mathrm{GwH}$ nr. 37/2002, I3 februari 2002, B.4.4: het besluit dat het voorwerp is geweest van de door de machtigingswet vereiste bekrachtiging, is zelf een wettelijke norm geworden vanaf de datum van inwerkingtreding ervan. 
vernietiging bij het Grondwettelijk Hof worden ingesteld. Aangezien het Hof bevoegd is zowel ten aanzien van de bekrachtigingswet als van het bekrachtigde machtenbesluit, betreft de toetsing door het Hof zowel de bekrachtigingswet als de bepalingen van het bekrachtigde bijzondere machtenbesluit.

97. Quid indien de voorgeschreven bekrachtigingswet een weerslag heeft op hangende rechtsgedingen? De omstandigheid dat de bekrachtigde koninklijke besluiten het voorwerp zijn van annulatieberoepen bij de Raad van State en dat de bekrachtiging ervan tot gevolg heeft dat dit rechtscollege onbevoegd wordt om die beroepen te behandelen, kan de wetgever er niet van weerhouden een bevoegdheid uit te oefenen die hij zich uitdrukkelijk heeft voorbehouden. Het Grondwettelijk Hof gaat ervan uit dat een bekrachtiging van een bijzondere machtenbesluit niet kan worden geacht tot doel of tot gevolg te hebben de koninklijke besluiten, waarvan de onwettigheid wordt aangevoerd, geldig te verklaren of tot doel te hebben zonder verantwoording een categorie van personen een jurisdictionele waarborg te ontnemen. ${ }^{229}$ In een arrest van 17 september 2003 merkt het Hof op dat de verzoekers voor de Raad van State wisten dat de bepalingen het voorwerp konden uitmaken van een wettelijke bekrachtiging die noodzakelijkerwijs tot gevolg zou hebben dat de beroepen bij de Raad van State zonder voorwerp zouden worden en dat de verzoekers bij dit rechtscollege hoofdzakelijk verschillen in behandeling aanvoerden die zij onverantwoord achtten. Vermits die verschillen in behandeling ook voor het Grondwettelijk Hof kunnen worden aangeklaagd, is de rechtsbescherming van de verzoekers niet aangetast. ${ }^{230}$

h. De wetgever kan een bekrachtigingstermijn niet retroactief wijzigen om een niet-tijdige bekrachtiging te dekken

98. Het gebeurt dat de wetgever de oorspronkelijke bekrachtigingstermijn laat verstrijken en dat het bijzondere machtenbesluit bijgevolg komt te vervallen. Kan de wetgever deze nalatigheid rechtzetten door de oorspronkelijk voorgeschreven bekrachtigingstermijn te verlengen of door alsnog een retroactieve bekrachtigingswet aan te nemen? Het antwoord luidt ontkennend. Deze techniek schendt het algemeen rechtsbeginsel van de niet-retroactiviteit van wetten en heeft tot gevolg dat een categorie van personen die door een fiscale maatregel wordt geraakt, getroffen wordt door een (nieuw) verschil in behandeling, vermits haar de waarborg wordt ontzegd volgens welke de wet enkel voor de toekomst geldt. Behoudens uitzonderlijke omstandigheden kan de wetgever een vervallen termijn derhalve niet retroactief verlengen. ${ }^{23 \mathrm{I}}$

229 GwH nr. I24/2002, Io juli 2002, B.4.3; zie ook GwH nr. 37/2002, I3 februari 2002, B.3.2.

$230 \mathrm{GwH}$ nr. I02/2003, 22 juli 2003, B.I6.7; GwH nr. III/2003, I7 september 2003, B.8.

$23 \mathrm{I} \mathrm{GwH} \mathrm{nr.} \mathrm{100/2003,} \mathrm{I7} \mathrm{juli} \mathrm{2003,} \mathrm{B.II.2;} \mathrm{GwH} \mathrm{nr.} \mathrm{60/2002,} 28$ maart 2002. In dit laatste arrest wordt beslist dat de laattijdige bekrachtiging geen schending uitmaakt van het gelijkheidsbeginsel omdat de Koning zich ertoe beperkt heeft een aantal technische voorschriften van EG-richtlijnen in het interne recht om te zetten, waarbij-zoals dit ook het geval zou zijn voor de wetgever zelf - hij in hoge mate gebonden is door de inhoud van de om te zetten bepalingen van de desbetreffende richtlijnen (B.2.5). 
Tegen die laattijdige bekrachtiging biedt een annulatieberoep bij de Raad van State of een rechterlijke toetsing op grond van artikel 159 van de Grondwet geen soelaas. Zelfs een laattijdige bekrachtiging heeft immers tot gevolg dat het bekrachtigde koninklijk besluit wordt omgevormd tot een wet in de formele zin. ${ }^{232}$ Deze rechtscolleges kunnen wel met een prejudiciële vraag dit grondwettigheidsbezwaar voorleggen aan het Grondwettelijk Hof.

\subsection{De hedendaagse terroristische dreiging en de rechterlijke controle}

99. De voorgaande voorbeelden hadden grotendeels betrekking op situaties die zich vele decennia geleden voordeden. Ook vandaag kunnen zich evenwel nog noodtoestanden voordoen. Daarbij kan in de eerste plaats worden gedacht aan terroristische activiteiten, en dit ongeacht de motieven die eraan ten grondslag liggen.

Terroristische dreigingen zetten de democratische rechtsstaat op tweevoudige wijze onder druk: enerzijds hanteren terroristen technieken die geen plaats hebben in een moderne samenleving om daarmee mensenrechten zoals het recht op leven te schenden, en anderzijds leidt de reactie van overheden op dergelijke feiten ook steevast tot het beperken van grondrechten. ${ }^{233}$ De overheid heeft de verplichting, onder meer op grond van de positieve verplichtingen die uit het EVRM voortvloeien, om het terrorisme te bestrijden, ${ }^{234}$ maar moet dit, zowel om juridische als om politieke redenen, doen binnen het rechtsstatelijke kader waartegen de terroristen zich afzetten. Dit betekent, in de woorden van het Israëlische Hooggerechtshof, dat de overheid het terrorisme moet bestrijden "met een hand op de rug vastgebonden en dus niet met onbeperkte middelen, zoals de terroristen dat doen". ${ }^{235}$

Binnen het bestek van deze bijdrage kan niet worden ingegaan op de vele wetgevende initiatieven die beogen het terrorisme te bestrijden. We trachten veeleer de rechtspraak van het Grondwettelijk Hof te systematiseren waarin antiterreurmaatregelen aan de grondrechten worden getoetst om aldus een kader te schetsen waaraan ook toekomstige antiterreurwetgeving zal moeten voldoen. Aangezien de rechtspraak van het Grondwettelijk Hof ook op dit punt sterk wordt beïnvloed door die van het EHRM (zie nr. 45), wordt eerst kort daarop ingegaan.

232 Cass. 24 april 2002, AC 2002, nr. 25I. De aangevoerde schending van de artikelen Io en II van de Grondwet werd door het Hof niet nader onderzocht omdat het middel op dat punt nietontvankelijk was wegens onduidelijkheid.

233 Speciaal VN-gezant K. Koufa, “Terrorism and human rights”, UN Doc. E/CN.4/Sub.2/1999/27; UN DOC. E/CN.4/Sub.2/200I/3I; UN Doc. E/CN.4/Sub.2/2002/35.

234 F. Bernard, "La Cour européenne des droits de l'homme et la lutte contre le terrorisme", RTDH 20I6, 44-46; O. De Schutter, "La Convention européenne des droits de l'homme à l'épreuve de la lutte contre le terrorisme”, in E. BRibosia en A. WEYEMBERGH (eds.), Lutte contre le terrorisme et droits fondamentaux, Brussel, Bruylant, 2002, 86-89.

235 HCJ no. 5100/94, Public Committee Against Torture in Israel e.a. (I999) PD53(4)8I7, § 39. 
Ioo. Uit de rechtspraak van het EHRM over antiterreurmaatregelen ${ }^{236}$ blijkt dat het Hof zich zeer begripvol toont ten aanzien van de moeilijke taak van de overheden die het terrorisme bestrijden, zij het zonder daarbij zijn vaste rechtspraak te verloochenen. Zo blijft het onderscheid tussen de notstandsfeste en de niet-notstandsfeste rechten ook in de context van het bestrijden van het terrorisme overeind.

IoI. Wat de notstandsfeste rechten betreft, oordeelt het Hof dat de terroristische context nooit als gevolg mag hebben dat de drempel om te beoordelen of een absoluut recht wordt geschonden, wordt verlaagd, en het stelt dan ook regelmatig een schending van deze rechten vast in zaken die betrekking hebben op antiterreurmaatregelen. ${ }^{237}$ Zo oordeelde het in de zaak Trabelsi t. België, die betrekking had op de uitlevering van een terrorist aan de Verenigde Staten van Amerika, waar hij een levenslange gevangenisstraf zonder kans op vervroegde vrijlating riskeerde, het volgende: "However, none of these factors have any effect on the absolute nature of Article 3. As the Court has affirmed on several occasions, this rule brooks no exception. The principle has therefore had to be reaffirmed on many occasions (...), to the effect that it is not possible to make the activities of the individual in question, however undesirable or dangerous, a material consideration or to weigh the risk of ill-treatment against the reasons put forward for the expulsion in order to determine whether the responsibility of the State is engaged under Article 3." 238

Niettemin stelt het Hof zich in de praktijk iets soepeler op bij het beoordelen of die drempel in casu is bereikt. Zo stond het uitzonderlijk de uitlevering van een terreurverdachte naar een land dat geen partij bij het EVRM was, toe, op grond van de enkele diplomatieke belofte dat hij er niet zou worden gefolterd. ${ }^{239}$ In afwijking van zijn gebruikelijke rechtspraak stond het ook een eenzame opsluiting gedurende meer dan acht jaren van een extreem gevaarlijke terrorist toe. ${ }^{240}$ Ook toen de Russische overheid een gijzelingsactie in een theater door Tsjetsjeense separatisten met veel geweld beëindigde, waardoor tientallen onschuldige slachtoffers vielen, stelde het Hof geen schending vast. ${ }^{24 \mathrm{I}}$

236 Zie voor meer details F. Bernard, "La Cour européenne des droits de l'homme et la lutte contre le terrorisme", RTDH 20I6, 43-59; S. KowalsKa, "Human Rights Protection and Terrorism - Reflections in the Context of Strasbourg Jurisprudence", Politické vedy 2015, 25-42; J.P. Loof, Mensenrechten en staatsveiligheid: verenigbare grootheden?, Nijmegen, Wolf Legal Publishers, 2005; L.-A. Sicilianos, "The European Court of Human Rights at a Time of Crisis in Europe", EHRLR 20I6, I2I-I35; S. SotTiaux, Terrorism and the Limitation of Rights. The ECHR and the US Constitution, Oxford, Hart Publishing, 2008, 67-32I; F. VAnneste, "Het Europese Hof voor de Rechten van de Mens en de overheden die terrorisme bestrijden: brothers in arms?”, RW 2003-2004, I665-I677; tot slot kan worden verwezen naar de Factsheet "Terrorism and the European Convention on Human Rights", samengesteld door de persdienst van het EHRM en beschikbaar via www.echr.coe.int/ Documents/FS_Terrorism_ENG.pdf.

237 Bvb. EHRM (GK) 28 februari 2008, Saadi t. Italië; EHRM (GK) Ig februari 2009, A. e.a. t. Verenigd Koninkrijk; EHRM 3 I januari 20I2, M.S. t. België; EHRM (GK) I3 december 20I2, El-Masri t. FYROM.

238 EHRM 4 september 20I4, Trabelsi t. België, § II8.

239 EHRM I7 januari 20I2, Othman (Abu Qatada) t. Verenigd Koninkrijk.

240 EHRM (GK) 4 juli 2006, Ramirez Sanchez t. Frankrijk.

24I EHRM 20 december 20II, Finogenove.a. t. Rusland. 
I02. Wat de niet-notstandsfeste grondrechten betreft, kan worden vastgesteld dat het Hof de verdragsluitende partijen een zeer ruime appreciatiemarge toekent om de nodige antiterreurmaatregelen te nemen, en dat het slechts zelden besluit dat het evenredigheidsbeginsel is geschonden. Het Hof vereist wel dat die maatregelen beperkt blijven tot het bekampen van het terrorisme, en geen spillover effect kennen. ${ }^{242}$ Het Hof aanvaardt bijna altijd de relevante maatregelen, ${ }^{243}$ al stelt het meestal als cruciale voorwaarde dat elke individuele toepassing van een antiterreurmaatregel ter toetsing kan worden voorgelegd aan een onafhankelijke rechter. Deze "proceduralisering" van de grondrechten in de context van de terreurbestrijding beoogt te vermijden dat wetgeving die op zichzelf legitiem is, wordt misbruikt voor andere doeleinden. Het Hof past die rechtspraak onder meer toe op infiltratietechnieken, telefoontaps, toegang tot geheime rapporten en het blokkeren van rekeningen. ${ }^{244}$

\section{b. Het Grondwettelijk Hof en antiterreurmaatregelen}

I03. De rechtspraak van het Grondwettelijk Hof vertoont een gelijkaardig beeld. Wat de notstandsfeste grondrechten betreft, is de rechtspraak van het Hof beperkt tot enkele toetsingen aan het strafrechtelijk wettigheidsbeginsel. Bij wet van I3 maart 2003 werd de rechtsmacht van de Belgische strafgerechten uitgebreid met bepaalde terroristische daden die op het grondgebied van een andere lidstaat van de Raad van Europa zijn gepleegd door een vreemdeling die zich ten tijde van de vervolging in België bevindt. ${ }^{245}$ Oorspronkelijk gold die nieuwe regeling enkel voor feiten gepleegd na haar inwerkingtreding, maar toen de Turkse terreurverdachte Fehriye Erdal in België opdook, werd, met het oog op haar vervolging, het temporele toepassingsgebied van die nieuwe rechtsmachtregeling retroactief uitgebreid naar feiten die voor de inwerkingtreding ervan waren gepleegd. Het Hof kwalificeerde die rechtsmachtregeling als materieel strafrecht, omdat zij een wettelijke grondslag schept voor een vervolging in België die ten tijde van de feiten nog niet mogelijk was. Vervolgens vernietigde het de terugwerkende kracht van de nieuwe rechtsmachtregeling op grond van artikel 7 EVRM, zonder daarbij rekening te houden met de terroristische context. ${ }^{246}$

Maar net zoals het EHRM stelt ook het Grondwettelijk Hof zich waar mogelijk soepel op inzake de drempel van de notstandsfeste grondrechten. Het lex certa-beginsel in artikel 7 EVRM laat, in tegenstelling tot het retroactiviteitsverbod in diezelfde bepaling, een dergelijke soepelheid toe. In zijn vroegere rechtspraak met betrek-

242 EHRM 2 december 20I4, Güler en Ugur t. Turkije, § 53: “(..) laws against terrorism should not be used as a pretext to limit legitimate religious activity".

243 Bvb. EHRM 2 oktober 2008, Leroy t. Frankrijk (een administratieve geldboete voor een cartoon die de aanslagen van II september 200I leek goed te keuren); EHRM 30 juni 2009, Herri Batasuna en Batasuna t. Spanje (de ontbinding van een politieke partij).

244 EHRM 6 september 1978 , Klass e.a. t. Duitsland (deze zaak is atypisch, omdat de enige controle op de toepassing van het wetgevend kader inzake telefoontaps werd uitgevoerd door de Bondsdag, op basis van verslagen van de bevoegde Minister, maar niet door een onafhankelijke rechter); EHRM 24 april I990, Kruslin t. Frankrijk; EHRM I5 juni I992, Lüdi t. Zwitserland; EHRM 26 mei 1993, Brannigan en McBride t. Verenigd Koninkrijk; EHRM I8 mei 20Io, Kennedy t. Verenigd Koninkrijk; EHRM (GK) I2 september 20I2, Nada t. Zwitserland.

245 Artikel ro, $6^{\circ}$ V.T.Sv.

$246 \mathrm{GwH}$ nr. 73/2005, 20 april 2005. 
king tot het lex certa-beginsel stelde het Hof zich streng op en besloot het tot schending van het strafrechtelijk wettigheidsbeginsel zodra de strafwet enige beoordelingsmarge aan de strafrechter liet. ${ }^{247}$ Toen het Hof echter werd geconfronteerd met strafwetgeving ter bestrijding van het terrorisme, versoepelde het zijn maatstaven en sloot het zich aan bij de minder strenge rechtspraak van het EHRM, volgens dewelke een misdrijf "voldoende duidelijk is omschreven wanneer de rechtzoekende, op basis van de bewoordingen van de strafbepaling en, indien nodig, met behulp van de interpretatie daarvan door de rechtscolleges, kan weten welke handelingen en welke verzuimen zijn strafrechtelijke aansprakelijkheid meebrengen". ${ }^{248}$ Dat nieuwe soepele criterium werd meteen toegepast op het begrip "terroristisch misdrijf" in de wet van is december 2003 betreffende terroristische misdrijven. Aangezien voor het betrokken misdrijf een bijzonder opzet moet worden aangetoond, achtte het Hof dit begrip voldoende duidelijk. ${ }^{249}$ In latere zaken aanvaardde het Hof op grond van dezelfde logica ook begrippen als "lidmaatschap van een terroristische organisatie" $25^{\circ}$ en "het publiekelijk ter beschikking stellen van een boodschap met het oogmerk aan te zetten tot het plegen van een terroristisch misdrijf". ${ }^{251}$

I04. Ook wat de niet-notstandsfeste grondrechten betreft, vertoont de rechtspraak van het Grondwettelijk Hof over antiterreurmaatregelen sterke gelijkenissen met de rechtspraak van het EHRM: in de evenredigheidstoets kent het een zeer aanzienlijke appreciatiemarge toe aan de wetgever, zodat het inhoudelijk nagenoeg alle maatregelen aanvaardt, voor zover de individuele toepassing ervan kan worden beoordeeld door een onafhankelijke rechter.

Op grond van die techniek verwierp het Hof grotendeels de beroepen tot vernietiging van de wet van 4 februari 2010 betreffende de methoden voor het verzamelen van gegevens door de inlichtingen- en veiligheidsdiensten. Gelet op de globaal toegenomen veiligheidsrisico's was de wetgever van oordeel dat zij dienen te beschikken over aanvullende wettelijke middelen om een effectief veiligheidsbeleid te voeren. ${ }^{252}$ Het Hof aanvaardde vanuit die doelstelling de nieuwe technieken van gegevensverzameling en zelfs het bijhouden ervan in een geheim dossier dat wel door de vervolgende autoriteiten in een strafzaak, maar niet door de verdediging mag worden ingekeken. Ter compensatie van dat procedurele nadeel vereiste het Hof echter dat een onafhankelijke en onpartijdige rechterlijke instantie de wettigheid van de procedure kan onderzoeken. Bovendien moet iedereen die het voorwerp heeft uitgemaakt van een gegevensverzameling na de vaststelling door de

247 GwH nr. 69/2003, I4 mei 2003; GwH nr. I36/2004, 22 juli 2004; GwH nr. I4/2005, I9 januari 2005.

248 Het eerste arrest waarin het Hof zich soepeler opstelde, was GwH nr. 92/2005, II mei 2005. De huidige formulering van het toetsingscriterium kwam voor het eerst voor in $\mathrm{GwH} \mathrm{nr}$. 71/2006, Io mei 2006, maar is duidelijk geïnspireerd op EHRM 25 mei I993, Kokkinakis t. Griekenland. Zie over deze evolutie A. Alen en K. Muylle, Handboek van het Belgisch Staatsrecht, Mechelen, Kluwer, 20II, 825-827; E. CLAEs, "Het strafrechtelijk legaliteitsbeginsel en de rechtspraak van het Arbitragehof. Erosie van legaliteit?", TBP 2006, 451-469.

249 GwH nr. I25/2005, I3 juli 2005.

$250 \mathrm{GwH}$ nr. I22/20I4, I9 september 20I4.

$25 \mathrm{I}$ GwH nr. 9/20I5, 28 januari 20I5. In dat arrest werden ook de strafbaarstellingen van "iedere persoon die een andere persoon werft voor het plegen van [terroristische] misdrijuen" en "onderrichtingen of de opleiding gegeven met het oog op het plegen van een van [terroristische] misdrijuen" voldoende duidelijk geacht.

252 Parl. St., Senaat, 2008-2009, nr. 4-I053/I, p. I. 
Bestuurlijke Commissie dat het bijhouden van de gegevens niet meer noodzakelijk is, spontaan op de hoogte worden gebracht van het bestaan van het dossier, zodat hij zijn procedurele rechten kan uitoefenen. ${ }^{253}$

Ook inzake de bijzondere opsporingsmethoden werd deze rechtspraak toegepast. In 2004 sprak het Hof zich uit over de wet van 6 januari 2003 betreffende de bijzondere opsporingsmethoden ${ }^{254}$ en enige andere onderzoeksmethoden, die vooral de strijd tegen de georganiseerde misdaad beoogde te bevorderen. Het Hof vernietigde gedeeltelijk de techniek van observatie omdat zij een te verregaande inbreuk maakte op het recht op eerbied voor het privé- en gezinsleven en vernietigde gedeeltelijk de technieken van infiltratie en uitlokking door politieofficieren wegens schending van de rechten van verdediging. Bovendien stelde het Hof vast dat de rechterlijke controle op de toepassing van die bijzondere opsporingsmethoden niet voldeed. ${ }^{255}$

In 2007 moest het Hof zich opnieuw uitspreken over bijzondere opsporingstechnieken, aangezien de wetgever met de wet van 27 december 2004 enerzijds beoogde rekening te houden met het voormelde arrest, maar anderzijds bepaalde technieken wenste uit te breiden in het kader van de strijd tegen het terrorisme. In zijn arrest verwees het Hof herhaaldelijk naar de doelstelling om het terrorisme te bestrijden, hetgeen inhoudelijk tot een terughoudender toetsing leidde. Uiteindelijk vernietigde het Hof voornamelijk het gebrek aan onafhankelijke rechterlijke controle op de geheime onderdelen van het strafdossier, al preciseerde het ook dat een informant die misdrijven pleegt om zijn dekmantel niet te verraden, geen toestemming mag krijgen om zelf de fysieke integriteit van derden te schenden. ${ }^{256}$

I05. Niettemin stelt het Hof zich in dergelijke zaken niet minder streng op dan de Europese rechtscolleges. Nadat het Hof van Justitie de Dataretentierichtlijn had vernietigd wegens schending van het recht op eerbied voor het privé- en gezinsleven, ${ }^{257}$ deed het Grondwettelijk Hof precies hetzelfde met de omzettingswet, in een arrest waarin voornamelijk werd geciteerd uit het Luxemburgse voorbeeld..$^{258}$

\section{c. Besluit}

Io6. Net zoals voor het EHRM maakt het voor het Grondwettelijk Hof niet uit of de terroristische dreiging al dan niet als "noodtoestand" is gekwalificeerd. Uit de samenvattingen van de argumenten van de partijen blijkt alvast dat de Ministerraad zichzelf voor het Hof nooit verdedigt met het argument van de noodtoestand.

$253 \mathrm{GwH}$ nr. I45/20II, 22 september 20II.

254 Het ging meer bepaald om het onderscheppen, het in beslag nemen en het openen van de post, de mogelijkheid voor de procureur des Konings om inlichtingen in te winnen over bankrekeningen en bankverrichtingen, de observatie, de infiltratie en de informantenwerking.

255 GwH nr. 202/2004, 2I december 2004.

256 GwH nr. 105/2007, I9 juli 2007.

257 HvJ 8 april 20I4, Digital Rights Ireland Ltd., C-293/I2 en Kärntner Landesregierung e.a., C-594/I2.

258 GwH nr. 84/20I5, II juni 2015. 
Dit is ook logisch, aangezien het evenredigheidsbeginsel alle elementen aanreikt die nodig zijn om een evenwicht te bereiken tussen twee essentiële aspecten van de overheidstaak in een democratische rechtsstaat, namelijk, enerzijds, het waarborgen van de openbare veiligheid, en, anderzijds, het waarborgen van de mensenrechten en van de normale werking van de instellingen. Naarmate de dreiging ernstiger en de potentiële gevolgen dramatischer worden, biedt het evenredigheidsbeginsel de overheid meer ruimte om grondrechten te beperken. De normale werking van de instellingen, alsook het in een rechtsstaat essentiële recht op toegang tot de rechter, vereisen wel dat die evenredigheid door een rechter wordt gecontroleerd (cfr. nr. 80). Het Grondwettelijk Hof voert die toetsing van het wetgevende kader in abstracto uit, terwijl de gewone rechter de individuele toepassingen van dat wettelijke kader in concreto kan onderzoeken. De proceduralisering van de grondrechten in de rechtspraak van het EHRM en van het Grondwettelijk Hof draagt ertoe bij dat die essentiële rechterlijke taak niet aan banden wordt gelegd.

I07. Die manier van werken sluit ook aan bij de visie in de Europese rechtsleer over de vraag of de grondrechtentoetsing een "balancing model" dan wel een "categorization model" moet volgen. De Amerikaanse doctrine en rechtspraak kennen in de strijd tegen het terrorisme een sterke voorkeur voor categorization, omdat de rechter daarbij een sterk gebonden bevoegdheid heeft en dus niet bij machte is om allerhande belangen tegenover elkaar af te wegen. Hij mag alleen maar nagaan of de feiten op een bepaalde manier moeten worden gekwalificeerd en moet daar de vooraf bepaalde rechtsgevolgen aan verbinden. Die manier van werken zou beter aansluiten bij de strijd tegen het terrorisme, omdat balancing de terroristen te veel ruimte zou geven. In zijn proefschrift toonde SotTiaux evenwel aan dat de Europese aanpak van balancing, waarbij de individuele rechten en belangen door de rechter worden afgewogen ten opzichte van de nagestreefde doelstelling van algemeen belang, een beter evenwicht tussen vrijheid en veiligheid waarborgt. ${ }^{259}$ Die aanpak hoeft geenszins te betekenen dat de strijd tegen het terrorisme niet meer op efficiënte wijze kan worden gevoerd, aangezien zowel het EHRM als het Grondwettelijk Hof de evenredigheidstoets bij dergelijke ernstige bedreigingen zeer terughoudend toepast.

Ten aanzien van het Grondwettelijk Hof geldt dus de conclusie die in de rechtsleer ook al ten aanzien van het EHRM werd gemaakt: het mensenrechtendiscours vormt geen obstakel om het terrorisme te bestrijden, maar vormt veeleer een aanvullende techniek om de democratische waarden hoog te houden, net zoals de strijd tegen het terrorisme dat doet. ${ }^{260}$ Vrijheid en veiligheid zijn dan ook geen tegengestelde waarden, maar zijn allebei essentiële aspecten van een rechtsstaat. ${ }^{26 r}$

259 S. Sottiaux, Terrorism and the Limitation of Rights. The ECHR and the US Constitution, Oxford, Hart Publishing, 2008, 406.

260 F. VAnNeste, "Het Europese Hof voor de Rechten van de Mens en de overheden die terrorisme bestrijden: brothers in arms?", RW 2003-2004, I665.

26I L.-A. Sicilianos, "The European Court of Human Rights at a Time of Crisis in Europe", EHRLR 2016, I35. 


\subsection{Conclusie}

Io8. In dit hoofdstuk werd vastgesteld dat de nobele doelstellingen die ten grondslag liggen aan artikel I87 van de Grondwet, niet kunnen verhinderen dat zich in de praktijk wel degelijk noodtoestanden voordoen. Er werd geen poging ondernomen om een typologie van noodtoestanden op te stellen, omdat een dergelijke lijst te zeer voor subjectieve invulling vatbaar is, terwijl bij uitstek in het noodrecht objectiviteit geboden is. Daarentegen werden vier types van oplossingen onderzocht die in het verleden aan noodtoestanden zijn gegeven. Drie oplossingen gingen uit van de juridische of de feitelijke wetgever, en zij hebben gemeenschappelijk dat zij de macht van de uitvoerende macht aanzienlijk hebben doen toenemen, zelfs tot ver buiten zijn normale grondwettelijke bevoegdheden. De vierde oplossing focust op de rechter, die zich bij zijn toetsing van maatregelen ter bestrijding van noodtoestanden, in casu terreurdreigingen, voldoende terughoudend opstelt om de actieradius van de overheid niet te zeer te beperken, zonder evenwel de basiswaarden van de grondrechtenbescherming uit te hollen.

Iog. Elk van deze vier oplossingen valt ook te rijmen met het verbod op noodrecht zoals dat uit artikel I87 van de Grondwet voortvloeit, al komt daar soms wat juridische creativiteit bij kijken.

De techniek van de besluitwetten houdt een afwijking van de grondwetsbepalingen met betrekking tot de werking van de instellingen in, ${ }^{262}$ omdat de wetgevende macht werd uitgeoefend zonder de Kamer van volksvertegenwoordigers en de Senaat, en tijdens de Tweede Wereldoorlog zelfs zonder de Koning. Zij vinden hun rechtvaardiging in een situatie van werkelijke overmacht, die voor dergelijke afwijkingen ruimte laat (zie nr. I6), in het continuïteitsbeginsel, dat zijn grondslag vindt in artikel 187 van de Grondwet, en in de verplichting om de onafhankelijkheid van het land te vrijwaren, die uit diezelfde bepaling voortvloeit.

De techniek van de buitengewone machtenwetten houdt eveneens een afwijking in van de grondwetsbepalingen met betrekking tot de werking van de instellingen, omdat zij aan de Koning dergelijk ruime bevoegdheden toekent dat hij de werkelijke spil van het beleid wordt. Die techniek vindt zijn rechtvaardiging in een ruimhartige lezing van artikel I05 van de Grondwet en, voor zover die lezing zou worden betwist, in artikel 187 van de Grondwet, dat de staatsmachten toelaat om de onafhankelijkheid van het land te vrijwaren, zelfs indien daarbij moet worden afgeweken van de grondwetsbepalingen met betrekking tot de werking van de instellingen (zie nr. 25). De onvolkomen rechterlijke toetsing van de besluiten die op grond van de buitengewone machten zijn genomen, moet in het toenmalige tijdskader worden gesitueerd; indien deze besluiten thans aan een rechter zouden worden voorgelegd, zal deze ze wellicht geen onweerlegbaar vermoeden van grondwettigheid meer toekennen, temeer daar hij ook de grondwettigheid van de

262 Al kunnen bepaalde besluitwetten inhoudelijk wel op gespannen voet met de grondrechten staan. Te denken valt vooral aan de besluitwet van iI oktober I9I6, die een afwijking van de grondrechten inhoudt die in het huidige constitutionele kader niet te verantwoorden valt (zie nr. 36). 
machtigingswet in vraag kan stellen aan de hand van een prejudiciële vraag aan het Grondwettelijk Hof.

In tegenstelling tot de twee voormelde technieken vinden de bijzondere machtenwetten toepassing in noodsituaties buiten het oorlogskader. De wetgever gebruikt de ruime appreciatiemarge die hem ter zake wordt toegekend door de Raad van State, afdeling Wetgeving en het Grondwettelijk Hof om in sociaal-economische crisissituaties bijzondere machten toe te kennen aan de Koning. Ook deze techniek houdt een afwijking in van de normale bevoegdheidsverdeling tussen de wetgevende en de uitvoerende macht, doordat de wetgever slechts vage doelstellingen opsomt en de werkelijke beleidsruimte aan de Koning laat. Er bestaat een ruime consensus dat deze techniek in het algemeen kan worden gerechtvaardigd op grond van artikel I05 van de Grondwet, zodat geen beroep op enige noodrechttheorie nodig is. Enkel wanneer een bijzondere machtenwet de Koning machtigt om essentiële elementen van door de Grondwet aan de wetgever voorbehouden materies te regelen, wordt afgeweken van de Grondwet. Zelfs de strikte criteria die de Raad van State, afdeling Wetgeving en het Grondwettelijk Hof voor dergelijke machtigingen hebben uitgewerkt, kunnen die techniek slechts "zo goed en zo kwaad als het gaat" ${ }^{263}$ in overeenstemming met de Grondwet brengen.

De vierde techniek stelt de constitutionele rechter centraal en focust op een van de belangrijkste hedendaagse noodtoestanden, namelijk de terroristische dreiging. De maatregelen om aan dergelijke dreigingen het hoofd te bieden, worden genomen door normaal functionerende instellingen, maar houden wel vaak beperkingen van de grondrechten in. In navolging van de richtinggevende rechtspraak van het EHRM kiest het Grondwettelijk Hof voor een terughoudende toetsing van dergelijke maatregelen, zonder de notstandsfeste grondrechten te veronachtzamen en zonder de niet-notstandsfeste grondrechten uit te hollen. Het Hof proceduraliseert de niet-notstandsfeste grondrechten door beperkingen erop weliswaar in abstracto te aanvaarden, maar niettemin te vereisen dat de gewone rechter een toetsing in concreto kan doorvoeren. Die strategie past volledig in de logica van het evenredigheidsbeginsel, dat in elk grondrecht vervat zit, aangezien een grotere dreiging meer doortastende maatregelen rechtvaardigt. Er is dus veeleer sprake van een toegelaten beperking van grondrechten dan van een verboden schorsing ervan, aangezien de rechterlijke toetsing overeind blijft. Artikel I87 van de Grondwet komt dus niet in het gedrang.

IIo. Dit maakt dat in het huidige kader slechts één norm van objectief staatsnoodrecht problematisch is in het licht van de Grondwet, namelijk de besluitwet van II oktober I9I6 (zie nr. 36). Zij is niet alleen onaangepast aan de evolutie in de technieken van oorlogsvoering en de technologische evoluties op het vlak van communicatiemiddelen, maar de structurele preventieve inbreuk op verschillende grondrechten die zij inhoudt, valt bovendien niet te rechtvaardigen, zelfs niet met een terughoudende evenredigheidstoets.

263 A. Mast en J. Dujardin, Overzicht van het Belgisch Grondwettelijk Recht, Brussel, Story-Scientia, I987, 226. 


\section{$4 \quad$ Nood aan hervorming van het noodrecht?}

III. De voorgaande hoofdstukken hebben aangetoond dat het Belgische staatsnoodrecht sterk afwijkt van dat van de meeste andere landen, in de zin dat artikel I87 van de Grondwet er amper ruimte voor biedt. ${ }^{264}$ Die bepaling laat slechts schorsingen toe van de grondwetsbepalingen die de werking van de instellingen regelen, en dan nog alleen in geval van werkelijke overmacht of indien de onafhankelijkheid van het land op het spel staat. Artikel I87 van de Grondwet heeft de politieke overheden nooit verhinderd om de noodtoestanden die zich voordeden, effectief te bekampen. De rechtspraak en de rechtsleer hebben zich steeds van hun meest creatieve kant laten zien om te bewijzen dat die technieken daadwerkelijk het strenge grondwettelijke kader eerbiedigen.

De laatste jaren gaan niettemin alsmaar meer stemmen op om het Belgische noodrecht in overeenstemming te brengen met dat van de buurlanden en daarbij de mogelijkheden te benutten die artikel I5 EVRM en artikel 4 IVBPR bieden, teneinde toekomstige noodtoestanden effectief te kunnen bekampen. ${ }^{265}$ In dit afsluitende hoofdstuk nemen we stelling in dit debat.

\section{I Noodrecht en artikel I87 van de Grondwet}

II2. Om te beginnen moet worden beklemtoond dat materieel of procedureel noodrecht naar huidig positief recht de rechterlijke toetsing slechts kan overleven voor zover het in de Grondwet wordt opgenomen. Men kan moeilijk voorhouden dat de Grondwet de hoogste norm in het staatsbestel is, waaraan de machten hun bestaansreden ontlenen, en zich vervolgens op het standpunt stellen dat de Grondwet alleen geldt in normale en niet in buitengewone omstandigheden (zie nrs. 4, 5 en I2). Een invoering van noodrecht vereist dus een grondwetsherziening. De auteurs die in het verleden een pleidooi hielden voor een noodrechtbepaling en hiervoor een tekstvoorstel redigeerden, hebben er bijgevolg steeds voor geopteerd om die bepaling in te lassen in de Grondwet. ${ }^{266}$ Het Parlement toonde in het

264 Ongeveer 90\% van de grondwetten zou een noodrechtbepaling bevatten (C. BJథRNSKOV en S. VoIGT, "The Determinants of Emergency Constitutions", working paper, http:/|papers.ssin.com/ sol3/papers.cfm?abstract_id=2697144, 2; Z. Elkins, T. Ginsburg en J. Melton, The Endurance of National Constitutions, Cambridge, Cambridge University Press, 2009).

265 Zie o.a. R. ERGEc, "L'état de nécessité en droit constitutionnel belge", in CIDP/ICSR (ed.), Le nouveau droit constitutionnel, Brussel, Bruylant, I987, I70-I7I; S. Sotriaux, "Nood aan een noodgrondwet?", Juristenkrant 9 december 2015, I2; S. VAN Drooghenbroeck, "L'article I87 de la Constitution", RBDC 2006, 295-296; J. Velaers en S. Van Drooghenbroeck, "Invoeging van een transversale bepaling in de Grondwet over het afwijken van rechten en vrijheden”, Parl. St. Kamer 2005-2006, nr. 5I-2304/00I, p. 94 .

266 A. Buttgenbach, "L'extension des pouvoirs de l'exécutif en temps de guerre et la révision de la Constitution belge", Belg. Jud., I935, 433-437; W.J. Ganshof van Der Meersch, Preadvies. De schorsing van de vrijheidsrechten in uitzonderingstoestand, in Vereniging voor de vergelijkende studie van het recht van België en Nederland Jaarboek III 1949-1950, Antwerpen, De Sikkel, Zwolle, W.E.J. Tjeenk Willink, 72; W.J. Ganshof van der Meersch en M. Diderich, "Les états d'exception et la Constitution belge", Ann. Dr. I953, I2I (voorstel voor een nieuw artikel I3obis van de Grondwet: de uitzonderingstoestand vereist 2/3 van de uitgebrachte stemmen in elke Kamer); zie ook J. VelaErs en S. Van Drooghenbroeck, "Invoeging van een transversale bepaling in de Grondwet over het afwijken van rechten en vrijheden", Parl. St. Kamer 2005-2006, nr. 5I-2304/00I, p. 93-94 en noot 83 . Voor een gedetailleerd overzicht van de diverse voorstellen in het Parlement en in de rechts- 
verleden weinig geestdrift voor hun voorstellen. Het meest recente voorstel werd op vraag van de Kamer van volksvertegenwoordigers een tiental jaar geleden uitgewerkt door de professoren Velaers en VAN Drooghenbroeck en wordt infra kort besproken (zie nr. I2I).

Dit betekent meteen ook dat tijdens de huidige legislatuur geen algemene noodrechtbepaling kan worden ingevoerd, aangezien artikel I87 van de Grondwet niet voor herziening vatbaar is en ook geen enkele andere voorgenomen herziening betrekking heeft op het noodrecht. ${ }^{267}$

\subsection{Argumenten voor en tegen een herziening van artikel 187 van de Grondwet}

II3. Voorstanders van de opname van een noodrechtbepaling in de Belgische Grondwet stellen vast dat de de iure Grondwet weliswaar uitzonderingstoestanden verbiedt, maar dat de de facto Grondwet ze wel toelaat, zoals blijkt uit de noodwetgeving die in het verleden is aangenomen. $\mathrm{Zij}$ betogen dat het beter is om die feitelijke toestand te officialiseren. ${ }^{268}$ Een opname van een noodrechtbepaling in de Grondwet zou immers toelaten om de grenzen van die mogelijkheid - zowel wat de situaties die als noodtoestand kunnen worden gekwalificeerd als wat de notstandsfeste grondrechten betreft - vast te stellen en de vereiste procedures te bepalen. ${ }^{269}$ Tot slot laat een noodrechtbepaling toe om maatregelen met slechts een tijdelijke draagwijdte te nemen, die slechts van toepassing blijven zolang de noodtoestand duurt. Die tijdelijkheid zou te verkiezen zijn boven wetgeving met een algemene draagwijdte die in een permanente beperking van grondrechten voorziet. ${ }^{270}$

II4. Wij zijn evenwel van mening dat een dergelijke bepaling onwenselijk en overbodig is. Zij is onwenselijk omdat het huidige artikel I87 van de Grondwet op symbolisch en rechtstheoretisch vlak één van haar belangrijkste bepalingen uitmaakt, als locus van het constitutionalisme (zie nr. 4) en als grondslag van het continuïteitsbeginsel en van de plicht om de Belgische onafhankelijkheid te vrijwaren (zie nr. 25). Zo'n fundamentele bepaling mag niet te lichtzinnig worden opgeheven, zeker niet in een tijd die wordt gekenmerkt door de "constitutionalisering" van de rechtsorde. ${ }^{271}$

II5. Het opheffen van artikel I87 van de Grondwet is ook overbodig, aangezien de overheid voldoende andere middelen te harer beschikking heeft om

leer: C. Huberlant, "Etat de siège eet légalité d'exception en Belgique", in Licéité en droit positif et références légales aux valeurs, Brussel, Bruylant, I982, 4I4-422.

267 Verklaring tot herziening van de Grondwet van 25 april 20I4, BS 28 april 20I4, p. 35I84.

268 R. ERgec, "L'état de nécessité en droit constitutionnel belge", in CIDP/ICSR (ed.), Le nouveau droit constitutionnel, Brussel, Bruylant, I987, I70-I7I; S. SotTIAUX, "Nood aan een noodgrondwet?", Juristenkrant 9 december 20I5, I2; S. VAN Drooghenbroeck, "L'article I87 de la Constitution", RBDC 2006, 295-296.

269 S. SotTIAUx, "Nood aan een noodgrondwet?", Juristenkrant 9 december 20I5, I2; S. VAN DroogheNBROECK, "L'article I87 de la Constitution", RBDC 2006, 295-296.

270 S. SotTiaux, “Nood aan een noodgrondwet?", Juristenkrant 9 december 20I5, I2.

27 W. VAn Gerven en S. Lierman, Algemeen deel. Veertig jaar later. Privaat- en publiekrecht in een meergelaagd kader van regelgeving, rechtsvorming en regeltoepassing, Mechelen, Kluwer, 20II, 27-32. 
noodtoestanden te bekampen. De oplossingen die in het verleden aan dergelijke crisissituaties zijn gegeven, blijken het grondwettelijke kader te eerbiedigen (zie nr. Io8), zodat er geen weg te werken discrepantie tussen de de facto en de de iure Grondwet bestaat. De juridische creativiteit die in het verleden aan de dag werd gelegd om bepaalde noodwetgeving te rechtvaardigen, pleit niet zozeer voor een herziening van artikel I87 van de Grondwet, maar toont veeleer aan dat ook binnen het huidige grondwettelijke kader voldoende soepel met noodtoestanden kan worden omgegaan.

Alleen de besluitwet van II oktober I9I6 schendt op verschillende punten de grondwettelijke rechten en vrijheden (zie nr. ${ }^{6} 6$ ). Het is echter de vraag of die ongrondwettigheid moet worden rechtgezet door de Grondwet aan te passen aan die besluitwet, dan wel om de omgekeerde oefening te maken. Verschillende beperkingen van grondrechten in die besluitwet staan niet alleen op gespannen voet met de Grondwet, maar eveneens met het EVRM en het BUPO. Zelfs indien de inhoud van de besluitwet een grondwettelijke goedkeuring zou krijgen, kan haar toepassing door de organen die toezien op de naleving van die verdragen, worden gesanctioneerd. Het lijkt dus veeleer aangewezen om de noodzaak en de evenredigheid van elk van die grondrechtenbeperkingen kritisch te onderzoeken ter gelegenheid van een inhoudelijke modernisering van de besluitwet, en om die grondrechtenbeperkingen die in een hedendaagse context niet door de beugel kunnen, te wijzigen of te schrappen. Indien er toch voor zou worden gekozen om enkele verregaande grondrechtenbeperkingen te behouden voor het geval dat een nieuwe oorlog uitbreekt, dienen de overeenkomstige grondwettelijke vrijheden daarmee in overeenstemming te worden gebracht, maar moet het toepassingsgebied van die herziening tot de hypothese van de staat van oorlog worden beperkt.

II6. Een gehele of gedeeltelijke schorsing van de Grondwet kan bestaan uit, enerzijds, een afwijking van de normale werking van en de verhouding tussen de instellingen, of, anderzijds, een opschorting van bepaalde grondrechten.

Wat de afwijking van de normale werking van de instellingen betreft, volstaat, in geval van een materiële onmogelijkheid voor een instelling om te functioneren, een toepassing van het beginsel van overmacht en van het beginsel van de continuïteit van de openbare dienst. Wanneer een instelling zich in de materiële onmogelijkheid om te functioneren bevindt, houdt dit op zichzelf al een feitelijke schorsing van de Grondwet in, aangezien de instellingen zelf hun bestaansrecht en hun bevoegdheden vinden in de Grondwet. Een tijdelijke overname van de bevoegdheden van de dysfunctionele instelling door de instelling die er het nauwst mee verwant is en die wel nog in staat is te functioneren, vermijdt dus veeleer een schending van artikel I87 van de Grondwet dan dat zij een schending ervan zou inhouden.

Indien een noodsituatie niet leidt tot de materiële onmogelijkheid voor een instelling om te functioneren, maar slechts vereist dat ingrijpende maatregelen worden genomen met een spoed die niet door de wetgevende procedure kan worden gewaarborgd, staat de techniek van opdrachtwetten sensu lato, die desgevallend bijzondere machtenwetten kunnen zijn, ter beschikking. 
Wat de opschorting van de grondrechten betreft, is een aanpassing van artikel I87 van de Grondwet evenmin vereist. Hoger werd aangetoond dat het evenredigheidsbeginsel dat inherent is aan elke grondrechtentoetsing, de overheid de noodzakelijke armslag biedt om noodtoestanden te bekampen, maar tegelijkertijd de abstracte en concrete toetsing van de genomen maatregelen door een onafhankelijke rechter verzekert (zie nr. Io6).

II7. Die evenredigheidstoets ontkracht overigens de discrepantie tussen de de iure Grondwet en de de facto Grondwet. Zowel de iure als de facto kan artikel I87 van de Grondwet gevrijwaard blijven, aangezien noodmaatregelen kunnen worden genomen zonder over te gaan tot een formele opschorting van de grondrechten, maar slechts door middel van een beperking ervan op grond van de gebruikelijke beperkingscriteria en onder rechterlijk toezicht.

De evenredigheidstoets heeft overigens nog minstens twee andere voordelen op een uitdrukkelijke noodrechtbepaling. Ten eerste valt zij beter te verzoenen met het gelijkheidsbeginsel. Een noodrechtbepaling creëert immers steeds een onderscheid tussen personen die bepaalde grondrechten geschorst zien en personen die hier niet mee geconfronteerd worden. Nochtans is het gelijke genot van de grondrechten voor eenieder precies een van hun wezenskenmerken. Die ongelijke behandeling valt ook moeilijk te verantwoorden indien er valabele en minder beperkende alternatieven bestaan voor de opschorting van grondrechten.

Ten tweede geldt in de hierboven beschreven toepassing van de evenredigheidstoets door het EHRM en het Grondwettelijk Hof de waarborg van de proceduralisering (zie nrs. I02 en I04). Beide rechtscolleges laten de wetgever en de uitvoerende macht toe om de niet-notstandsfeste grondrechten verregaand te beperken in de mate waarin de noodtoestand zulks vereist, maar zij beklemtonen wel dat de individuele toepassing van de genomen maatregelen steeds door een onafhankelijke rechter moet worden gecontroleerd. Wanneer echter de noodtoestand wordt afgekondigd en bepaalde grondrechten worden opgeschort, dreigt het recht op toegang tot de rechter een van de voornaamste slachtoffers te zijn, aangezien rechterlijk toezicht van aard is om de effectiviteit van de genomen maatregelen te verminderen.

Een afwezigheid van rechterlijk toezicht zou overigens niet alleen een opschorting van grondrechten betekenen, maar ook een opschorting van de normale werking van de rechterlijke macht en dus van een van de wezenskenmerken van de Belgische staatsinrichting, het beginsel van de scheiding der machten. Hoewel de Grondwet die termen niet uitdrukkelijk hanteert, heeft zij België opgevat als een rechtsstaat met een sterke scheiding der machten. ${ }^{272}$ Het is in een dergelijke staatsopvatting essentieel dat burgers die zich door een overheidsoptreden gegriefd voelen, toegang hebben tot een onafhankelijke en onpartijdige rechter om dat optreden aan te klagen. Rechterlijk toezicht op elk overheidsoptreden lijkt ons ook in geval van

272 A. Alen, "Scheiding" of "samenwerking" der machten?, Academiae Analecta, Mededelingen van de Koninklijke Academie voor Wetenschappen, Letteren en Schone Kunsten van België, Brussel, I990, 73 p. 
noodtoestand een minimum minimorum te zijn, zonder hetwelk het rechtsstatelijke kader wordt verlaten.

II8. Wat het argument van de tijdelijkheid van noodmaatregelen betreft, kan worden vastgesteld dat ook dit een element is dat door de rechter in de evenredigheidstoets sensu lato van de genomen maatregelen moet worden betrokken. Aangezien een maatregel die is genomen om aan een noodtoestand te verhelpen, zijn noodzakelijkheid slechts behoudt zolang die noodtoestand aanhoudt, zal de rechter een individuele toepassing van die maatregel na afloop van de noodtoestand buiten toepassing moeten laten. Niets weerhoudt de overheid er trouwens van om ook buiten het formele kader van een noodrechtbepaling de tijdelijkheid van de genomen noodmaatregelen te stipuleren.

Ook blijkt het in de hedendaagse context niet evident om noodtoestanden als voorbijgaande episodes te beschouwen. De terroristische dreiging duurt reeds verscheidene jaren en het ziet er niet naar uit dat zij snel van de baan zal zijn. De maatregelen die worden genomen in de strijd tegen het terrorisme, zullen in de praktijk een zeer lange geldingsduur moeten hebben en passen dus niet noodzakelijk in het kader van een in de tijd afgebakende uitzonderingstoestand.

Bepaalde antiterreurmaatregelen vereisen overigens uit hun aard een permanent karakter. Zo kunnen de maatregelen die de werking van de inlichtingendiensten regelen, en die met andere woorden moeten waarborgen dat elke mogelijke bedreiging van de openbare veiligheid zo snel mogelijk wordt gedetecteerd en geneutraliseerd, niet worden opgeheven zodra een terroristische dreiging afneemt. Dergelijke maatregelen moeten structureel van aard zijn om voldoende snel op elke toekomstige dreiging te kunnen anticiperen. Om te vermijden dat die maatregelen te ver gaan, volstaat de gebruikelijke evenredigheidstoets in abstracto en in concreto (zie nr. ro6). ${ }^{273}$

II9. Tot slot mag ook het gevaar van een oneigenlijk gebruik van een noodrechtbepaling niet worden veronachtzaamd. Uit onderzoek blijkt dat het afkondigen van de noodtoestand vaak als doel heeft om politiek voordeel te halen uit de noodsituatie die zich voordoet, om onpopulaire maatregelen te vermommen en om de rechterlijke macht tot een terughoudender toetsing aan te zetten. ${ }^{274}$ Het afkondigen van een noodtoestand voedt bovendien uit zichzelf de angst en de onzekerheid bij de bevolking en maakt de situatie vaak erger dan zij in werkelijkheid is.

Bij toepassing van grondwettelijke noodrechtbepalingen dreigt met andere woorden veel sneller het rechtsstatelijke karakter van de samenleving onder druk te komen dan bij toepassing van de normale beperkingscriteria van grondrechten. Nochtans is het essentieel om met name bij het bekampen van degenen die de hedendaagse Westerse waarden beogen te vernietigen, zelf die waarden hoog in

273 Bvb. GwH nr. I45/20II, 22 september 201 I.

274 E. Hafner-Burton, L. Helfer en C. Fariss, "Emergency and Escape: Explaining Derogations from Human Rights Treaties”, International Organization 20II, 675. 
het vaandel te blijven houden. Of om het in de woorden van het EHRM te stellen: er moet worden vermeden dat de rechtsstaat wordt beschadigd of zelfs vernietigd onder het mom van zijn bescherming. ${ }^{275}$

\subsection{Toch een uitdrukkelijke noodrechtbepaling?}

a. Algemeen

I20. Ondanks het voorgaande is het aangewezen om - in ondergeschikte orde - te onderzoeken aan welke vereisten een uitdrukkelijke grondwettelijke noodrechtbepaling zou moeten beantwoorden, voor het geval dat er één zou worden ingevoerd. Vooreerst vereist het evenredigheidsbeginsel dat de duur van de noodtoestand strikt beperkt blijft tot de noodwendigheden van de crisissituatie. Die vereiste van tijdelijkheid moet uitdrukkelijk in de noodrechtbepaling worden opgenomen.

Cruciaal in een democratische rechtsstaat is ook dat een noodrechtbepaling voldoet aan de vereisten van evenredigheid en subsidiariteit. ${ }^{27}$ Dit betekent dat een noodrechtbepaling geschikt moet zijn voor het beoogde doel en noodzakelijk moet zijn om dat doel te bereiken. Daarenboven mag de overheid geen beroep doen op een noodrechtbepaling indien ze door de toepassing van de gewone rechtsregels hetzelfde resultaat kan bereiken (zie nr. 47). Tevens moet een noodrechtbepaling rekening houden met de omstandigheid dat bepaalde grondrechten voor de overheid onaantastbaar zijn, en dus minstens de notstandsfeste grondrechten uit artikel I5 EVRM en artikel 4 IVBPR vrijwaren. Bovendien moet de wetgevende macht, gelet op de economie van de Belgische Grondwet, het laatste woord hebben over de wenselijkheid van het instellen van de noodtoestand, behoudens wanneer zij als gevolg van de crisissituatie niet in staat zou zijn om te vergaderen. Tot slot mag geen afbreuk worden gedaan aan de rechterlijke toetsing in abstracto en in concreto van de genomen vrijheidsbeperkende maatregelen.

\section{b. Het voorstel van de professoren Velaers en Van Drooghenbroeck}

I2I. Het voorstel van de professoren Velaers en VAN Drooghenbroeck voor een nieuwe noodrechtbepaling heeft betrekking op maatregelen die afwijken van de grondrechten in Titel II van de Grondwet, en regelt, gelet op de opdracht die de bevoegde Kamercommissie hun had toebedeeld, niet de situatie van de gedeeltelijke schorsing van grondwetsbepalingen die de werking van de instellingen regelen. De tekst van hun voorstel luidt als volgt:

275 EHRM (GK) 6 september 1978 , Klass e.a. t. Duitsland, § 49.

276 Zie in verband met de in abstracto criteria H.R.B.M. Kummeling, "Recht in nood", in Crises, rampen en recht, Handelingen Nederlandse Juristen-Vereniging 20I4-I, 268-275. 
"1. In tijd van oorlog (of in geval van enig andere, door of krachtens een wet vastgestelde en officieel afgekondigde, algemene noodtoestand welke het bestaan van het volk bedreigt), kunnen maatregelen worden genomen die afwijken van de waarborgen die titel II van de Grondwet biedt.

2. De afwijkende maatregelen zijn slechts verantwoord voor zover ze strikt noodzakelijk zijn, zonder discriminatie worden genomen, en niet worden misbruikt om de rechten en vrijheden te vernietigen, doch ertoe strekken het voortbestaan van de democratische rechtsstaat te verzekeren.

3. De voorgaande bepalingen wettigen geen enkele afwijking van de artikelen 14bis, 18, 19 en 20, wat de vrijheid van godsdienst en levensbeschouwing betreft.

4. De afwijkende maatregelen welke op grond van de voorgaande bepalingen kunnen worden genomen, worden door of krachtens een wetgevende norm vastgesteld."277

I22. Het toepassingsgebied in punt I van dit voorstel is in sterke mate gebaseerd op artikel I5 EVRM. Die gelijkenis biedt het belangrijke voordeel van de rechtszekerheid, aangezien het waarborgt dat alleen de situaties die volgens het EVRM als noodtoestand worden gekwalificeerd, tot een gedeeltelijke schorsing van de Belgische Grondwet kunnen leiden. Het staat de Belgische grondwetgever echter vrij om, gelet op artikel 53 van het EVRM, in een ruimere rechtsbescherming te voorzien, door de grondwettelijke noodrechtbepaling een beperkter toepassingsgebied te geven.

Wij zijn voorstander van een beperkter toepassingsgebied, dat neerkomt op het schrappen van de bewoordingen die de professoren Velaers en VAN DrooghenbroecK in hun voorstel tussen haakjes hebben geplaatst. ${ }^{278}$ Dit zou immers neerkomen op de situaties die de onafhankelijkheid van het land in het gedrang brengen, terwijl in de situaties waarin zulks niet het geval is, de grondrechten slechts kunnen worden beperkt, maar niet geschorst. Meer bepaald komt deze schrapping tegemoet aan de hoger vermelde vaststelling dat het inlassen van een ruime staatsnoodrechtbepaling om terroristische misdrijven te bekampen, vanuit rechtsstatelijk oogpunt geen goede optie is (zie nr. IIg) en gelet op de terughoudende rechterlijke toepassing van de evenredigheidstoets ook niet nodig is (zie nr. Io6).

I23. Het voorstel vereist terecht dat de noodtoestand formeel wordt afgekondigd, hetgeen in de logica van de Belgische Grondwet een wetgevende tussenkomst vereist, zoals in punt 4 van het voorstel is opgenomen. Die logica beperkt in zekere zin de aantasting van Titel II van de Grondwet, die voor een beperking van grondrechten meestal een wetgevende handeling vereist (zie nr. 9).

277 J. Velaers en S. Van Drooghenbroeck, "Invoeging van een transversale bepaling in de Grondwet over het afwijken van rechten en vrijheden", Parl. St. Kamer 2005-2006, nr. 51-2304/00I, p. 93.

278 Zie voor de redenen daarvoor J. Velaers en S. VAN Drooghenbroeck, "Invoeging van een transversale bepaling in de Grondwet over het afwijken van rechten en vrijheden", Parl. St. Kamer 2005-2006, nr. 5I-2304/00I, p. 85-86. Zij vermelden met name het gevaar dat een regering die niet meer de steun van het volk geniet, de noodtoestand uitroept om aan de macht te blijven (zie ook W.J. Ganshof van der Meersch en M. Diderich, "Les états d'exception et la Constitution belge", Ann. Dr. I953, I04-I06. Anders: C. Huberlant, "Etat de siège et légalité d'exception en Belgique", in Licéité en droit positif et références légales aux valeurs, Brussel, Bruylant, I982, 423). 
In tijden van oorlog vindt steeds een machtsconcentratie in handen van de uitvoerende macht plaats (zie nr. 29). De betrokkenheid van de volksvertegenwoordiging kan dan worden verzekerd door te bepalen dat de Kamer van volksvertegenwoordigers onverwijld na het intreden van de uitzonderingstoestand die het gevolg is van het vaststellen van de staat van oorlog, wordt bijeengeroepen, zodat zij kan oordelen over het geheel of gedeeltelijk voortduren ervan. ${ }^{279}$

I24. Het voorstel maakt daarentegen wel de keuze om geen waarborg in te bouwen ter vrijwaring van het verbod op preventieve maatregelen dat Titel II van de Grondwet evenzeer kenmerkt. Die keuze neemt afstand van de optie om een ruimere rechtsbescherming dan het EVRM en het IVBPR te bieden, alsook van een van de motieven van de Belgische revolutie en een van de meest fundamentele keuzes van de grondwetgever van I83I.

I25. Het voorstel voldoet aan de criteria van evenredigheid en subsidiariteit, die uitdrukkelijk worden opgenomen in punt 2 ervan. ${ }^{280}$ Hieraan zou nog kunnen worden toegevoegd dat de rechterlijke toetsing van de genomen maatregelen niet mag worden opgeschort. ${ }^{281}$ De overheid moet ook in een uitzonderingstoestand de volgende grondrechten en verboden respecteren: het verbod op het invoeren van de doodstraf en de burgerlijke dood (de artikelen I4bis en I8), de vrijheid van godsdienst en levensbeschouwing. De overige door Titel II van de Grondwet gewaarborgde grondrechten zouden in tijd van oorlog of in geval van een algemene noodtoestand wel geschorst kunnen worden, maar voor die schorsingen bieden het verbod van misbruik, het discriminatieverbod en de proportionaliteits- en subsidiariteitsvereisten een bijkomende waarborg.

Deze lijst komt niet helemaal overeen met die van de notstandsfeste grondrechten in het EVRM en het IVBPR. Het verbod van foltering en van onmenselijke of vernederende behandeling of straf en het verbod van slavernij of dienstbaarheid kennen geen equivalent in de Belgische Grondwet, maar het strafrechtelijk legaliteitsbeginsel van artikel 7 EVRM is wel analoog aan de artikelen I4 en I2, tweede lid, van de Grondwet. Dat niet alle notstandsfeste grondrechten uit artikel I5 EVRM en artikel 4 IVBPR bijkomend worden opgenomen, kan echter worden verklaard door de stelling van de auteurs dat het, omwille van de evidentie, niet nodig is te stipuleren dat ook bij toepassing van het noodrecht de internationale verdragen van toepassing blijven. ${ }^{282}$

279 Zie in die zin artikel I03.3 van de Nederlandse Grondwet: "Terstond na de afkondiging van een uitzonderingstoestand en voorts, zolang deze niet bij koninklijk besluit is opgeheven, telkens wanneer zij zulks nodig oordelen beslissen de Staten-Generaal omtrent het voortduren daarvan; zij beraadslagen en besluiten terzake in verenigde vergadering."

280 Zie hierover J. Velaers en S. Van Drooghenbroeck, "Invoeging van een transversale bepaling in de Grondwet over het afwijken van rechten en vrijheden”, Parl. St. Kamer 2005-2006, nr. 5I-2304/oor, p. 89-9o.

28I Zie de suggestie in die richting in J. Velaers en S. Van Drooghenbroeck, "Invoeging van een transversale bepaling in de Grondwet over het afwijken van rechten en vrijheden", Parl. St. Kamer 2005-2006, nr. 5I-2304/00I, p. 88.

282 J. Velaers en S. Van Drooghenbroeck, "Invoeging van een transversale bepaling in de Grondwet over het afwijken van rechten en vrijheden”, Parl. St. Kamer 2005-2006, nr. 5I-2304/ooI, p. 9I. 
I26. Een dergelijke noodrechtbepaling zou slechts een gedeeltelijke verankering bieden van de besluitwet van II oktober I9I6, die immers ongeacht het afkondigen van de noodtoestand onverkort aan de internationale mensenrechtenverdragen kan worden getoetst. Een eventuele invoeging van een noodrechtbepaling in de Grondwet mag bijgevolg niet als voorwendsel worden gebruikt om de actualisering van die besluitwet uit te stellen. Omgekeerd vormt die besluitwet op zich een onvoldoende reden om een noodrechtbepaling in de Grondwet in te schrijven.

\section{$5 \quad$ Besluit}

I27. De meeste landen kennen een systeem van objectief staatsnoodrecht, doorgaans bestaande uit een grondwetsbepaling die uiteenzet in welke omstandigheden de noodtoestand kan worden uitgeroepen, welk orgaan daarvoor bevoegd is en welke maatregelen kunnen worden genomen. Vaak laten dergelijke technieken toe om tijdelijk af te wijken van het normale grondwettelijke kader. De Franse julirevolutie van I830 en de invloed van de Franse filosoof Benjamin ConstanT DE REBECQUe hebben de grondwetgever van I83I ertoe aangezet om een systeem van een geheel andere orde aan te nemen: artikel 187 van de Grondwet bepaalt dat de Grondwet nooit geheel of gedeeltelijk kan worden geschorst. Die bepaling verzet zich tegen het formeel afkondigen of het de facto vestigen van een uitzonderingstoestand. Zelfs het bestaan van een noodtoestand laat in beginsel geen uitzondering op die in absolute termen geformuleerde bepaling toe.

Het is dus slechts in zoverre die bepaling zelf noodrecht rechtvaardigt, dat een gedeeltelijke schorsing van de Grondwet tot de mogelijkheden behoort. Ondanks zijn schijnbaar absolute formulering biedt artikel 187 van de Grondwet daarvoor ruimte in twee omstandigheden. De eerste omstandigheid is die van werkelijke overmacht. Indien de instellingen in de absolute onmogelijkheid verkeren om hun taken volgens de normale procedures uit te oefenen, is er sprake van een de facto schorsing van de Grondwet. Het beginsel van de continuïteit, dat eveneens zijn grondslag vindt in artikel I87 van de Grondwet, vereist dan dat wordt gekozen voor het minste kwaad: een uitoefening van de machten door een ander orgaan of volgens een andere procedure is te verkiezen boven een afwezigheid van machtsuitoefening. De tweede omstandigheid is die waarin de noodtoestand van dien aard is dat de onafhankelijkheid van het land in het gedrang komt. Een verlies van de onafhankelijkheid houdt een totale schorsing van de Grondwet in, en artikel I87 van de Grondwet gebiedt alle machten om die situatie te voorkomen of te bestrijden, ook al kunnen de omstandigheden in dat geval vereisen dat zulks gebeurt door middel van een geringe schorsing van bepaalde grondwetsbepalingen.

Slechts in die twee gevallen kan worden afgeweken van de grondwetsbepalingen die de normale werking van de instellingen regelen. Maar zelfs die situaties kunnen niet rechtvaardigen dat een formele beslissing zou worden genomen waarbij het genot van bepaalde grondrechten zou worden opgeschort. Het volstaat om desgevallend, en volgens de criteria die de Grondwet en de internationale mensenrechtenverdragen bepalen, maatregelen te nemen die bepaalde grondrechten beperken. Cruciaal daarbij is dat een onafhankelijke rechter de subsidiariteit en de evenredigheid van die maatregelen kan toetsen, en dit zowel in abstracto (het 
Grondwettelijk Hof) als in concreto (de gewone en de administratieve rechter), een mogelijkheid die in geval van de schorsing van een grondrecht zou wegvallen. Dat laatste zou moeilijk te verzoenen zijn met één van de kernaspecten van het rechtsstaatsbegrip, namelijk het rechterlijk toezicht op het overheidshandelen.

I28. De rigiditeit van dit grondwettelijke kader impliceert meteen dat de Belgische overheid, naar huidig positief recht, geen beroep kan doen op de noodrechtbepalingen in artikel I5 EVRM en artikel 4 IVBPR. Het beginsel van de ruimste rechtsbescherming heeft immers niet alleen betrekking op de inhoudelijke draagwijdte van een grondrecht, maar ook op de beperkingscriteria.

I29. Nobele principes verhinderen evenwel niet dat zich in de praktijk noodsituaties kunnen voordoen. In de Belgische geschiedenis waren de beide wereldoorlogen het voorbeeld bij uitstek van een noodtoestand die de Belgische onafhankelijkheid in het gedrang bracht. De maatregelen die werden genomen om aan die noodtoestand te verhelpen, werden niet steeds door de grondwettelijk bevoegde organen en volgens de grondwettelijke procedure aangenomen. De technieken van de besluitwetten en van de buitengewone machtenwetten vinden evenwel allebei hun ultieme rechtvaardiging in artikel I87 van de Grondwet zelf, gelet op de reden waarom zij in het leven werden geroepen.

De inhoud van de besluitwetten en van de besluiten die werden aangenomen op grond van buitengewone machten, kon in die dagen amper aan rechterlijke toetsing worden onderworpen. Aangezien de besluitwetten met formele wetten moeten worden gelijkgesteld, was elk rechterlijk toezicht erop onbestaande. Wat de buitengewone machtenbesluiten betreft, beperkte zowel de vaagheid van de machtigingen als de rechtspraak van het Hof van Cassatie de mogelijkheid van rechterlijke toetsing aanzienlijk.

Het constitutionele kader is sinds de Tweede Wereldoorlog op dat vlak sterk veranderd. Formele wetgeving kan aan de Grondwet en aan internationale verdragen worden getoetst en het rechterlijk toezicht op het overheidsoptreden wordt als een van de meest essentiële kenmerken van de rechtsstaat beschouwd. Het verdient daarom aanbeveling om bepaalde regels te herbekijken en in overeenstemming met de Grondwet te brengen, hetgeen best gebeurt in het kader van een algemene actualisering ervan. Met name de besluitwet van II oktober I9I6 betreffende de staat van oorlog en de staat van beleg is aan herziening toe, zowel omwille van haar onaangepastheid aan de moderne technieken van oorlogsvoering en moderne communicatiemiddelen als omwille van de aanzienlijke en structurele inbreuk die zij makt op verschillende grondrechten. Die herziening geschiedt het best in alle rust en in vredestijd, zodat het regelgevend kader klaar is in het geval zich ooit nog een staat van oorlog op het Belgische grondgebied zou voordoen.

I30. Niet alle crisissituaties hebben evenwel met een oorlog te maken. Een groot aantal uitdagingen van voornamelijk budgettaire of sociaal-economische aard werden in het verleden aangepakt door middel van bijzondere machtenwetten, die de Koning een ruimere regelgevende bevoegdheid toekennen dan degene die hij uit de Grondwet put. Hoewel de grondwettigheid van die techniek steeds in vraag is gesteld, werd een grondslag ontwikkeld die aansluit bij de tekst van een grond- 
wetsbepaling. Alleen in zoverre aan de Koning een machtiging wordt verleend in materies die door de Grondwet aan de wetgever worden voorbehouden, staat zij op gespannen voet met de Grondwet. De zeer strikte voorwaarden waaraan de afdeling Wetgeving van de Raad van State en het Grondwettelijk Hof de delegaties in voorbehouden materies onderwerpen, dekken die ongrondwettigheid niet helemaal toe.

I3I. De voornaamste crisissituatie van de huidige tijd is de terroristische dreiging. De laatste jaren heeft de wetgeving die beoogt terroristische handelingen te vermijden en te sanctioneren, een hoge vlucht genomen en bij elke aanslag neemt ook de roep om nieuwe en strengere maatregelen toe. Er wordt dan ook vaak gepleit voor maatregelen die neerkomen op verregaande beperkingen van grondrechten.

Ook die maatregelen ontsnappen evenwel niet aan de rechterlijke toetsing. Bovendien is artikel I87 van de Grondwet ten volle van toepassing op de terreurdreiging, die noch een situatie van werkelijke overmacht, noch een bedreiging van de Belgische onafhankelijkheid uitmaakt. Deze maatregelen moeten dus alle grondwettelijke en verdragsrechtelijke grondrechten eerbiedigen. In de praktijk blijkt dat de rechters zich bij deze toetsing, die vaak neerkomt op een evenredigheidstoets, terughoudend opstellen, omwille van het grote belang van een effectieve terreurbestrijding. Die terughoudendheid komt evenwel niet neer op een de facto afwezigheid van de grondrechten. De notstandsfeste grondrechten blijven overeind en ook de niet-notstandsfeste grondrechten worden niet uitgehold. Die laatste categorie van grondrechten wordt door het EHRM en door het Grondwettelijk Hof "geproceduraliseerd", hetgeen inhoudt dat de meeste beperkingen op deze grondrechten die in het kader van de terreurbestrijding worden aangenomen, worden aanvaard, voor zover elke concrete toepassing ervan aan de rechterlijke toetsing onderworpen blijft.

132. Die terroristische dreiging doet ook de roep toenemen om het grondwettelijke kader inzake de noodtoestand te herzien, door een bepaling in te voegen die structurele afwijkingen van grondrechten toelaat in een min of meer afgebakend aantal situaties. In hoofdorde hebben wij tegen een dergelijke optie gepleit, onder meer omdat de terughoudende rechterlijke toetsing een beter evenwicht tussen terreurbestrijding en mensenrechten waarborgt dan bepaalde radicale maatregelen die ook van toepassing kunnen zijn op andere situaties. Bovendien toont de juridische creativiteit die in het verleden aan de dag werd gelegd om (al bij al beperkte) afwijkingen van het grondwettelijke kader in crisissituaties te rechtvaardigen met een beroep op datzelfde grondwettelijke kader, aan dat artikel I87 van de Grondwet geen absoluut beletsel hoeft te zijn voor een effectieve crisisbestrijding.

In ondergeschikte orde pleiten wij ervoor om een dergelijke grondwettelijke noodrechtbepaling met voldoende waarborgen te omgeven. Minstens moet de rechterlijke controle gevrijwaard blijven, teneinde het risico op misbruik van de noodtoestand in te dijken.

Onze bezorgdheid in dit opzicht is vooral ingegeven door een vrees voor de uitholling van het rechtsstatelijke kader, niet alleen door een te ruime interpretatie van het begrip "noodtoestand" en dus door een te ruime toepassing van het noodrecht, maar ook door het gevaar van het hellend vlak. Meer fundamenteel is de 
vaststelling dat personen en organisaties die terroristische aanslagen plegen, dit vaak precies doen om de West-Europese waarden, waaronder die van de democratische rechtsstaat, te bestrijden. Het laatste dat men dan mag doen, is zelf aan de erosie van de rechtsstaat bij te dragen. In dat opzicht kan worden verwezen naar de woorden van Benjamin FrankLin: "Those who would give up essential liberty to purchase a little temporary safety, deserve neither liberty nor safety." 283

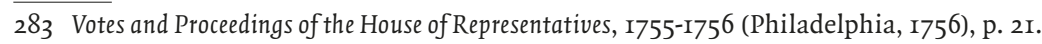

